\title{
NBSIR 75.680
}

\section{Mobile Home Construction Standards}

Adopted by State Regulatory Programs -.An Analysis

\section{P. W. Cooke, L. P. Zelenka, and}

H. K. Tejuja

\section{CES Project}

Office of Building Standards and Codes Services

Center for Building Technology, IAT

National Bureau of Standards

Washington, D. C. 20234

March 1975

Preliminary Report

Prepared in conjunction with:

Office of Housing Technology

Center for Building Technology Institute for Applied Technology National Bureau of Standards 

NBSIR 75-680

MOBILE HOME CONSTRUCTION STANDARDS

ADOPTED BY STATE REGULATORY PROGRAMS

\section{- -AN ANALYSIS}

P. W. Cooke, L. P. Zelenka, and

H. K. Tejuja

\section{CES Project}

Office of Building Standards and Codes Services

Center for Building Technology, IAT

National Bureau of Standards

Washington, D. C. 20234

March 1975

Preliminary Report

Prepared in conjunction with:

Office of Housing Technology

Center for Building Technology

Institute for Applied Technology

National Bureau of Standards

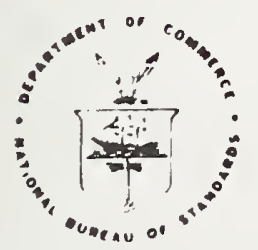

U. S. DEPARTMENT OF COMMERCE, Frederick B. Dom. Secretary 


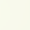




\section{PREFACE}

This study was prepared in conjunction with the office of Housing Technology in the Center for Building Technology, Institute for Applied Technology, National Bureau of Standards. Mr. James G. Gross and Mr. James H. Pielert, both of that office, provided initial direction for the study.

Appreclation is extended to the building code officials who administer and enforce mobile home regulatory programs in the various States for providing significant information for this study. Delegates to the National Conference of States on Building Codes and Standards (NCSBCS), some of whom also administer their States' mobile home regulatory programs, also reviewed and commented on a preliminary draft compilation of data at the Northeastern Reglonal Meeting of NCSBCS at Providence, Rhode Island, in September 1974. 
This study examines the extent to which the nationally recognized standard for the construction of mobile homes (i.e., ANSI Standard A119.1/NFPA 501B) has been adopted and amended by the individual States that have implemented enforcement programs for the regulation of mobile homes. Summary data is presented on the existing status of the various versions of the standard adopted in each State. State-adopted amendments to the technical requirements in the national standard are compiled by State and construction discipline for comparative analysis.

Key words: enforcement; legislation; mobile homes; regulation; standards; state-ofthe-art study; trailers. 
$\underline{\text { Page }}$

Preface . . . . . . . . . . . . . . . . . . . . . . . 1

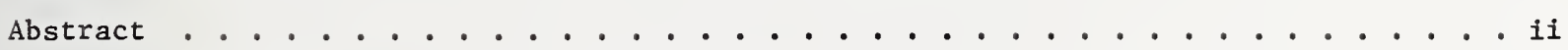

1. Background Information ....................... . 1



3. Relationship Between ANSI and NFPA Standards . . . . . . . . . . . . . . 2

4. Profile of State-Adopted Mobile Home Standards . . . . . . . . . . . . . 3

5. Analysis of Amendments--Compiled by State . . . . . . . . . . . . . . 8

6. Analysis of Amendments--Compiled by Construction Discipline . . . . . . . . . . 14

Part A-General . . . . . . . . . . . . . . . . . . . . 16

Part B--Construction Requirements . . . . . . . . . . . . . . . . . . 19

Part C--Plumbing Systems . . . . . . . . . . . . . . . . . . 53

Part D--Heating Systems . . . . . . . . . . . . . . . . . . . 69

Part E--Electrical Systems . . . . . . . . . . . . . . . . . . 81

7. References . . . . . . . . . . . . . . . . . . . 89

Appendix A . . . . . . . . . . . . . . . . . . . . . . 90

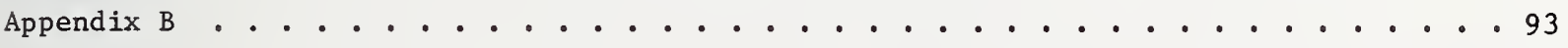

Appendix C . . . . . . . . . . . . . . . . . . . . 101 



\author{
Mobile Home Construction Standards \\ Adopted by \\ State Regulatory Programs--An Analysis \\ Patrick W. Cooke, \\ Louis P. Zelenka, \\ and Hotchand K. Tejuja
}

\title{
1. Background Information
}

As of July 1974, forty-five of the fifty States had enacted legislation requiring the establishment of mobile home regulatory programs[1]*. Among the regulatory powers contained in these laws is the requirement that mobile homes sold within the States' borders be designed and built in compliance with State-adopted construction standards. Although the specific provisions in the laws often vary from State to State, several of the acts directly refer to the requirements set forth in nationally recognized standards promulgated by the American National Standards Institute (i.e., ANSI Standard Al19.1) or the corresponding requirements established by the National Fire Protection Association (NFPA) in its Standard $501 B[2] *$.

The laws of other States, however, are not as specific--some merely require that whatever code is acopted for the construction of mobile homes be "reasonably consistent" with the ANSI (or NFPA) Standard. In two States, California and Washington, the regulations are generally compatible with the nationally recognized construction standards for mobile homes except where precluded by other statutes or where the State felt that the national standards did not provide minimum health and safety requirements. This situation results in what will be classfied as the adoption of a "state-written" code in these two States for purposes of this study.

While a small minority of State mobile home laws have provisions for automatic acceptance of revised editions of the ANSI or NFPA Standard, most States have not adopted such a provision. This allows almost all the States the flexibility to enforce different versions of the ANSI Standard--some of which are not necessarily current with the state-of-the-art. It also promotes non-uniformity of standards between States even though the laws themselves typically contain a reciprocity provision which allows for the interstate acceptance of mobile homes among States whose codes and enforcement programs are equivalent.

Further contributing to the non-uniformity of mobile home construction standards on a national level are a series of individual state-adopted amendments to the ANSI Standard. These amendments are usually in the form of individual State-adopted additions, deletions, or modifications to the technical content of a specific requirement (or definition) in the standard. The amendment process does not normally require the State legislature to act again; an administrative agency can amend the standard (or code) by itself usually after public hearings on the amendments have been held. Some modifications are intended to be administrative clarifications by the State authority having jurisdiction, while others are attributable to the application of special environmental conditions (e.g., snow loads, wind loads) on a statewide basis rather than limited to the area of the State included within a particular weather zone (e.g., hurricane wind).

of greater significance, however, is the fact that the list of State by State amendments to the ANSI Standard does contain some major changes (or restrictions) to the code provisions which have a direct impact on the mobile home industry as well as the single standard concept. A sampling of the more significant State-adopted variations to the ANSI Standard disclosed from the information compiled in this study include the following:

- Restriction on the use of copperclad and aluminum wire--Alaska (partial restriction) and Nevada.

*Figures in brackets indicate the literature references listed in section 7. 
o Installation of ground fault interrupters--Arizona.

- Substantial adoption of the National Electrical Code (NFPA 70, 1971 Edition) for electrical requirements in lieu of Part $E$ of the ANSI Standard--California.

- Requirement for 100 amp electrical service--Florida.

- More restrictive flame spread rating performance requirements--Michigan (partial restriction), Nevada (partia1 restriction), and New York

- Plans for the physically handicapped--Michigan.

- Restriction on use of plastic pipe for hot and cold water distribution system-North Carolina.

- Restriction on use of anti-siphon trap vent devices--Utah and Washington.

- Prohibited use of black steel pipe for drain waste and vent system--Wisconsin.

The objective of this study was to examine and analyze the content of the mobile home construction standards and codes adopted nationwide by individual States and compare them with the most current versions of the applicable ANSI Standard (i.e., ANSI A119.1, 1974 and 1975 Editions). The information presented in this study report is a profile of the existing status of the mobile home construction standards currently being enforced by the States and an analysis of the known variations that directly or indirectly amend the established provisions contained in those standards. In reporting the information compiled herein, no attempt has been made to assess the technical adequacy (or inadequacy) of any of the reported departures, additional requirements or restrictions to the established national standards for the construction of mobile homes.

\section{Data Collection}

State-of-the-art studies of State mobile home and manufactured building regulatory programs were initiated by the office of Building Standards and Codes Services (OBSCS) in 1972 as one of the tasks of the Coordinated Evaluation System (CES) Project[3]. The purposes of this task were: (1) to gather detailed background data for the development of model informational documentation[4] and (2) to provide data for state-of-the-art reports on mobile home and manufactured building regulatory programs.

Primary data for this study were obtained from existing CES background information (i.e., State laws, rules and regulations, administrative bulletins, etc.) and recent contacts with delegates to the National Conference of States on Building Codes and Standards (NCSBCS), some of whom administer their States' mobile home regulatory program. Also, data for other States were obtained directly from the appropriate State regulatory agency to augment any missing or outdated reference information on file.

The name of the department or agency responsible for the administration and enforcement of each State's mobile home regulatory program along with its address and the cognizant person to contact are given in appendix A. Because the States are introducing changes in their mobile home regulatory programs continually, the actual status of some items of tabulated data reported herein may be changed by the time of publication. For this reason, key State officials are identified by name, address, and telephone number in appendix $A$ so that the latest details on individual States may be obtained directly.

\section{Relationship Between ANSI and NFPA Standards}

Currently, American National Standards Institute (ANSI) Standard A119.1, 1975 Edition, and National Fire Protection Association (NFPA) Standard NFPA 501B, 1974 Edition, are identical[2]. They set forth minimum criteria for the construction of the body and frame of mobile homes, and the installation of electrical, plumbing, and heating systems. In recent years the standard has been updated and revised annually. Because ANSI regularly 
publishes revised editions of the standard after submitting proposed amendments to its members for approval based on consensus, their designation of the equivalent NFPA version differs by a year. NFPA coordinates proposed revisions to the standard which are drafted by task forces of experts in each area of regulation and approves them at its annual meetings.

The following editions of the ANSI and NFPA versions of the standard are equivalent and are generally those that have been reported to be in effect in the State regulatory programs covered by this report.

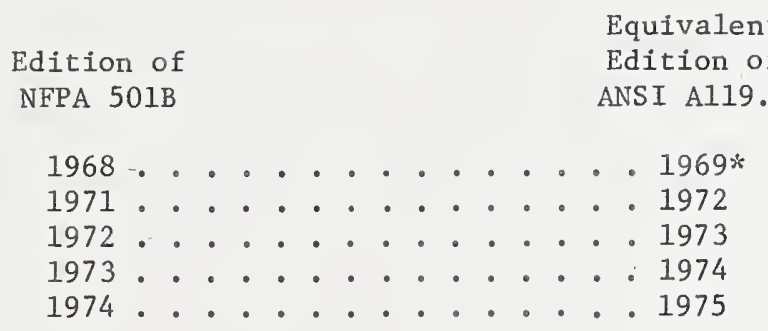

\section{Profile of State Adopted Mobile Home Standards}

Table 1 provides information in summary form on the status of the mobile home construction standards adopted by the States. This overview table indicates that forty-five of the States have adopted standards relative to mobile home construction. Five States- Hawail, New Hampshire, Oklahoma, Vermont, and Wyoming--had no mobile home regulatory program in effect nor any standard to enforce at the time this data was collected. The last column of the table contains the date (month-year) that the information for this table was obtained.

Among the forty-five States with regulatory authority to enforce mobile home construction standards, table 1 indicates that twenty-one States, or slightly less than half, have made at least one amendment to the basic standard currently adopted. The table also shows the relative distribution of the approximately one hundred and nine State-adopted amendments within the five major functional categories*\% of the ANSI Standard and also the general classification of each amendment--i.e., whether the individual departure was considered to be an addition, deletion, or modification to the existing requirements in the basic standard.

The breakdown of States by edition-year of the basic ANSI (or NFPA) Standard adopted is as given by the listings which follow. This same information has been depicted graphically on the outline map in figure 1.

\footnotetext{
*ANSI at this time operated under the name of American Standards Association (ASA).

**The ANSI Standard is divided into five major Parts, as follows:

Part A - General

Part B - Body and Frame Design and Construction Requirements

Part C - Plumbing Systems

Part D - Heating, Cooling, and Fuel-Burning Systems

Part E - Electrical Systems
} 


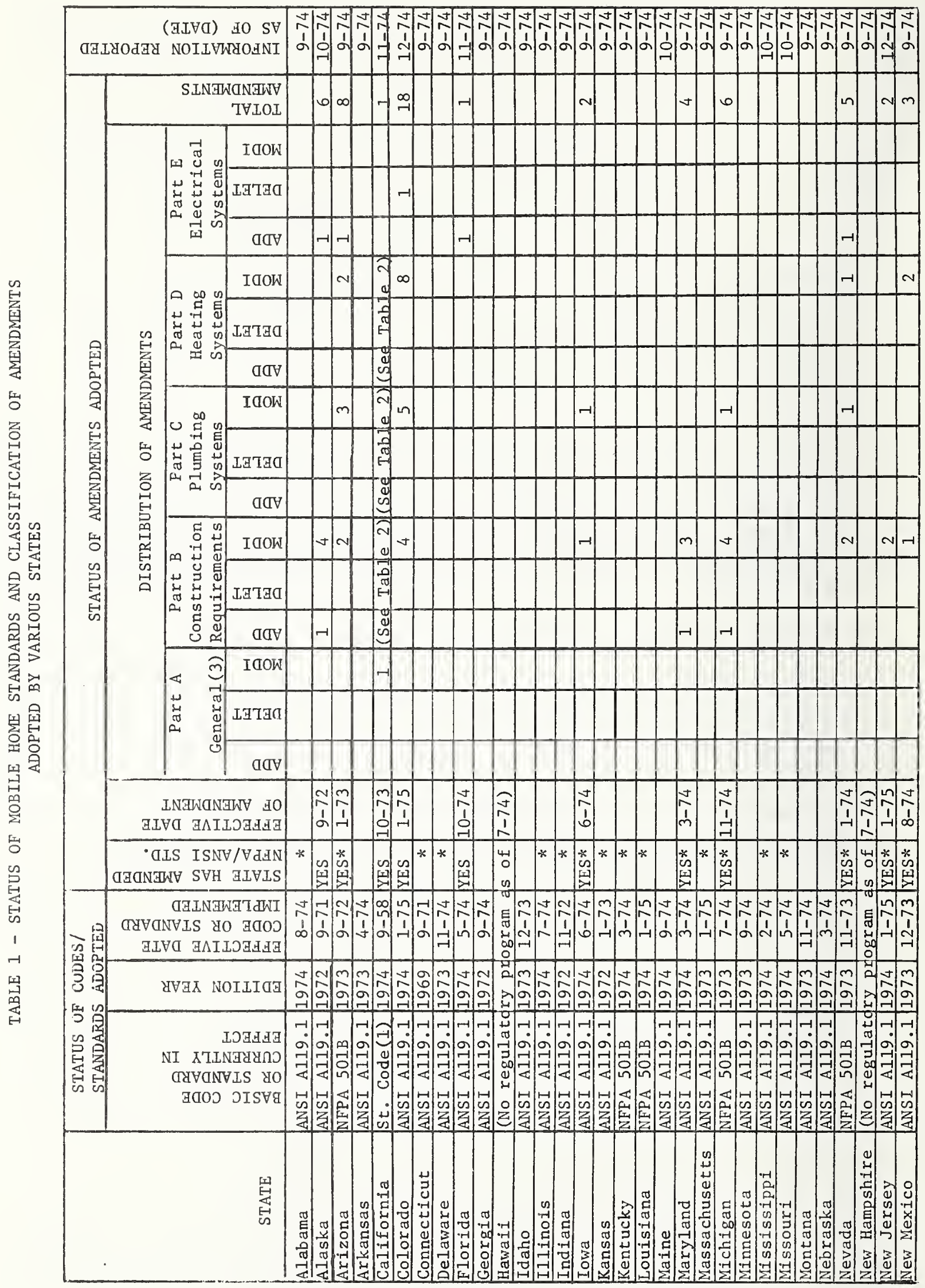




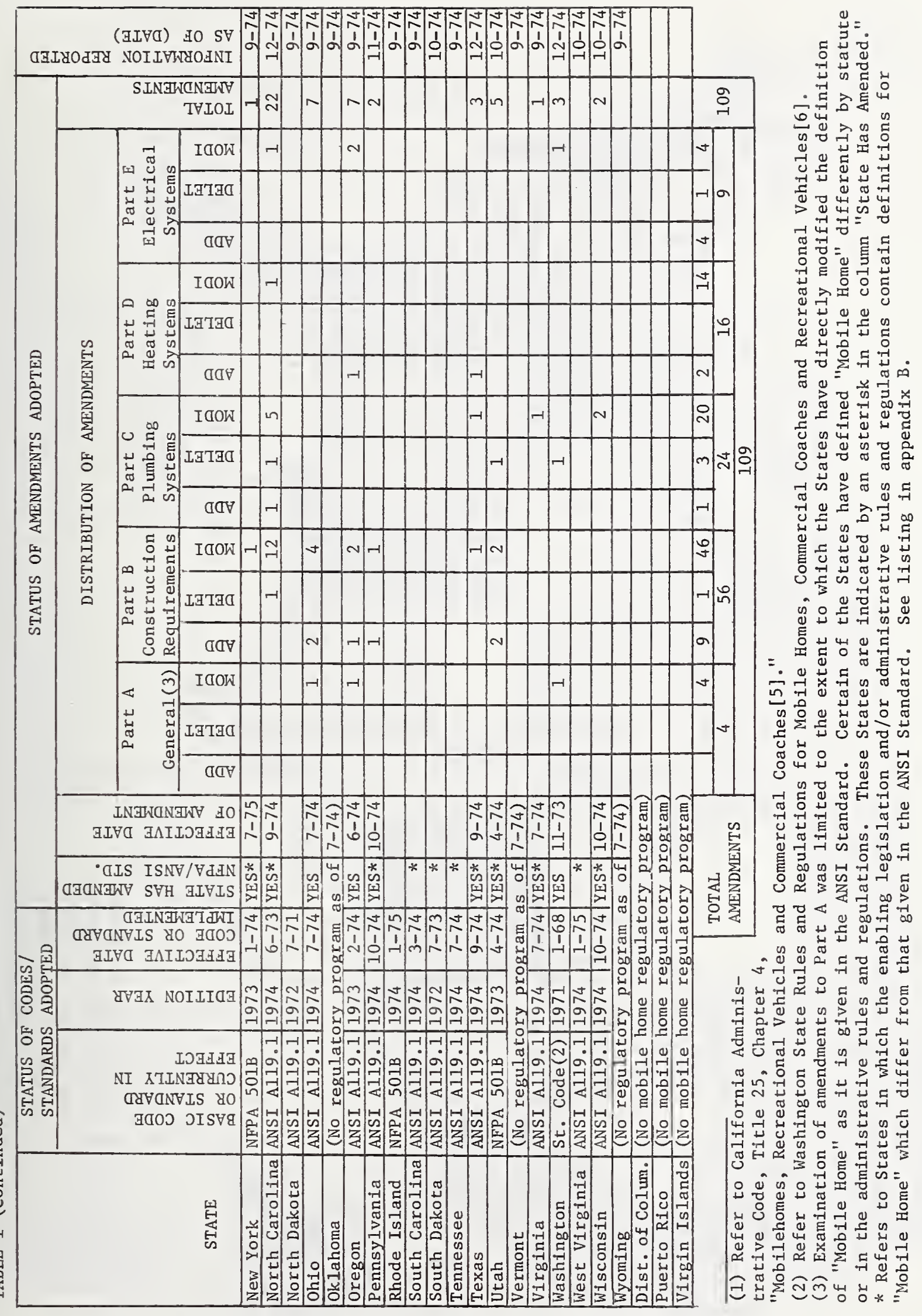



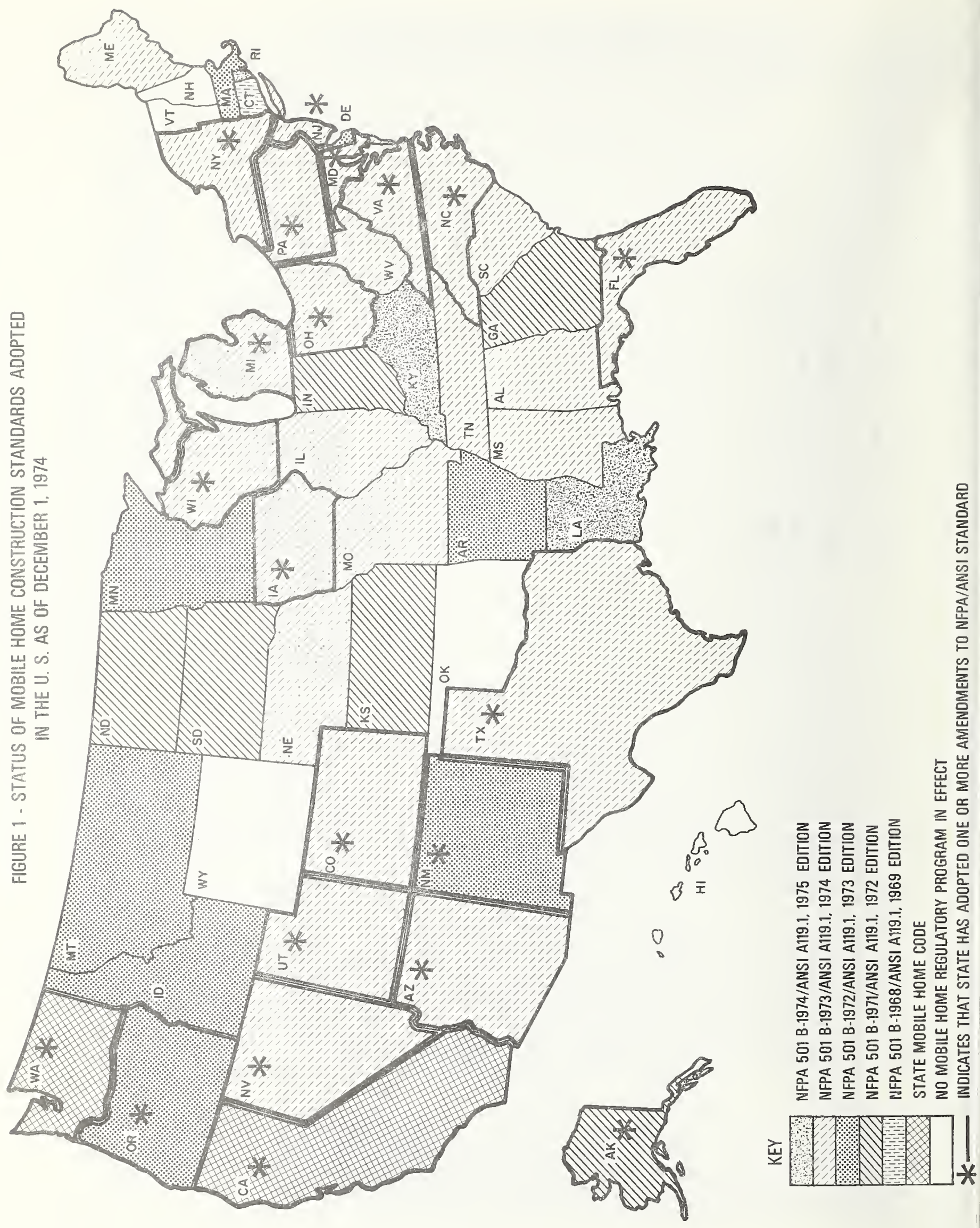
Adopted Without Amendments

1. Kentucky

2. Louisiana

3. Rhode Island
Adopted With Amendments

(none)

\begin{tabular}{l|l}
\multicolumn{2}{c}{ NFPA 501B-1973/ANSI A119.1-1974 Edition } \\
Adopted Without Amendments & Adopted With Amendment \\
\hline 1. Alabama & 1. Arizona \\
2. Illinois & 2. Colorado \\
3. Maine & 3. Florida \\
4. Mississippi & 4. Iowa \\
5. Missouri & 5. Maryland \\
6. Nebraska & 6. Michigan \\
7. South Carolina & 7. Nevada \\
8. Tennessee & 8. New Jersey \\
9. West Virginia & 9. New York \\
& 10. North Carolina \\
& 11. Ohio \\
& 12. Pennsylvania \\
& 13. Texas \\
& 14. Utah \\
& 15. Virginia \\
& 16. Wisconsin
\end{tabular}

NFPA 501B-1972/ANSI Al19.1-1973 Edition

Adopted Without Amendments

1. Arkansas

2. Delaware

3. Idaho

4. Massachusetts

5. Minnesota

6. Montana
Adopted With Amendments

1. New Mexico

2. Oregon

\section{NFPA 501B-1971/ANSI A119.1-1972 Edition}

Adopted Without Amendments
1. Georgia
2. Indiana
3. Kansas
4. North Dakota
5. South Dakota

Adopted With Amendments

1. Alaska

\section{NFPA 501B-1968/ANSI A119.1-1969 Edition}

Adopted Without Amendments

1. Connecticut
Adopted With Amendments

(none) 
The ANSI Standard does form the technical basis for regulation in the States of California and Washington, but because of substantial modifications both in format and content from that contained in the national standards, these two States have been classified as having State written codes for purposes of this report.

The overall situation with respect to the enforcement of various editions of the national standards and their respective amendment status is summarized in the following breakdown.



This summary indicates that about half the States have adopted the 1974 Edition of the ANSI Standard (NFPA 501B-1973), which is also the version that has been amended most frequently. It accounts for about seventy-five percent of all the amendments tabulated. Examination of the individual modifications, however, indicates that a portion of the State amendments were later approved by NFPA and ANSI for adoption in subsequent editions of the standard. Also, a significant number of these amendments are probably intended to be an individual State's clarification of a code requirement which is open to interpretation.

Many of the States with enabling legislation for the regulation of mobile home construction have defined the term "mobile home" in their statutes and administrative rules and regulations differently from that given in Part A of the ANSI Standard. Four States-California, Ohio, Oregon, and Washington--however, have each specifically changed the definition contained in the standard. Table 1 identifies thirty other States whose enabling legislation or administrative rules and regulations have a definition for "mobile home" which differs from that in the ANSI Standard (see asterisks in fifth column, "State Has Amended NFPA/ANSI Standard" of table 1)." These definitions, though different, apparently do not affect the terminology adopted in the national standard for purposes of construction requirements. The definitions from these thirty States have been compiled and are presented in appendix $B$.

The amendments contained in table 1 will be further analyzed in the following two report sections where they will be compiled and identified by State (in section 5) and then collated and compared with the corresponding provisions contained in the most recent editions of the ANSI Standard (i.e., 1974 and 1975 versions) in section 6.

\section{Analysis of Amendments--Compiled by State}

The amendments adopted by the twenty-one States identified in table 1 have been further summarized by State and are presented in table 2 in accordance with the applicable section designation from the ANSI Standard. The extent of each indicated amendment will be further examined in the next section of the report which is organized by technical discipline according to the contents of the ANSI Standard.

Amendments which have been classified as "additions" do not relate to any existing provision in the standard and have arbitrarily been given section designations from the standard in what was determined to be the most likely functional area to which they pertain. 
The individual States that have adopted the most amendments or interpretive clarifications to the basic standard are:

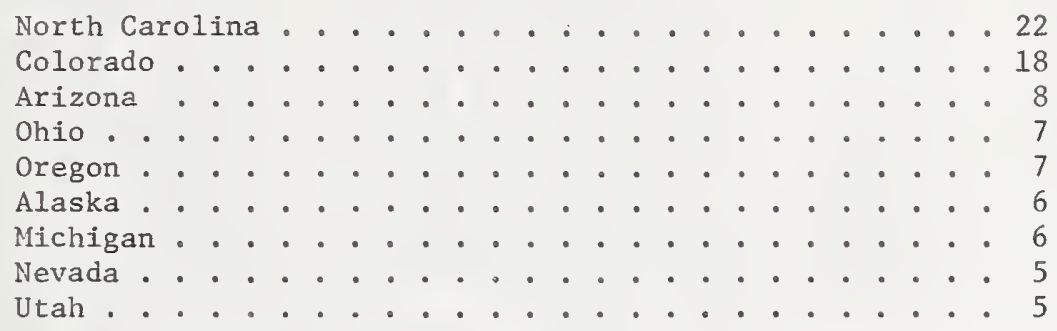




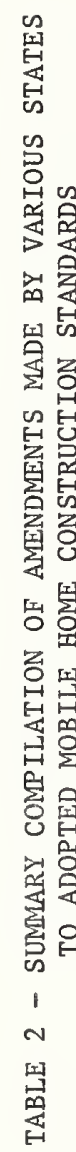

\begin{tabular}{|c|c|c|c|c|c|c|}
\hline \multirow{5}{*}{\multicolumn{2}{|c|}{  }} & 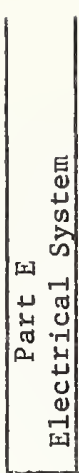 & 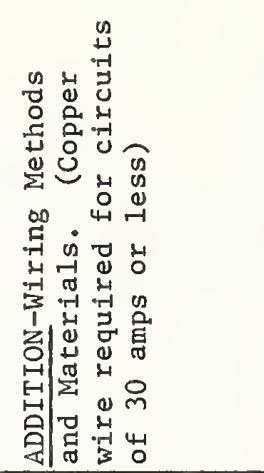 & 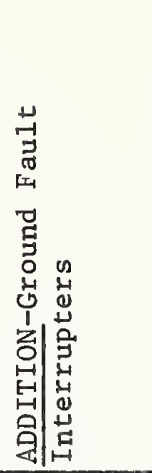 & 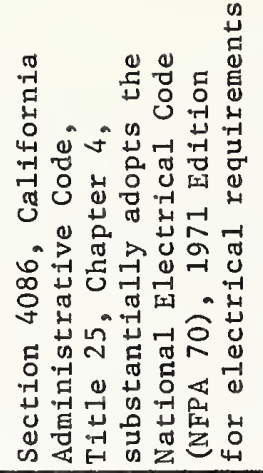 & 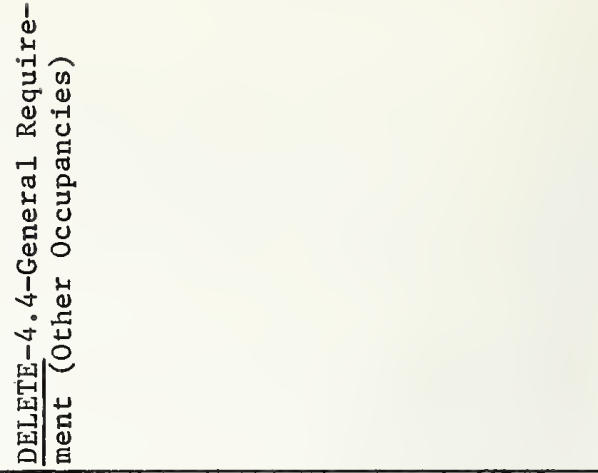 \\
\hline & & 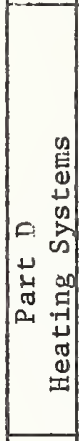 & & 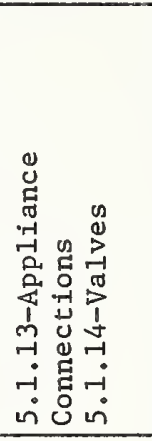 & 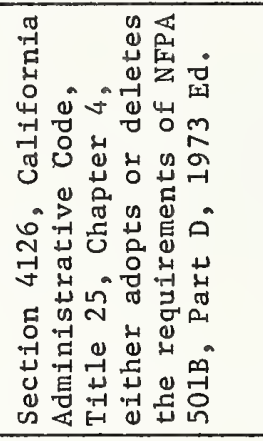 & 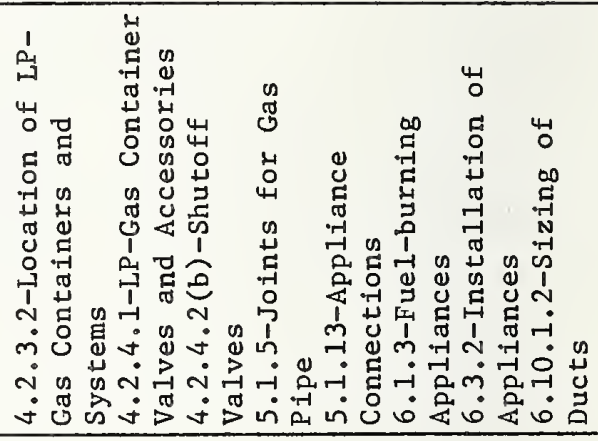 \\
\hline & & 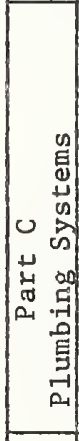 & &  & 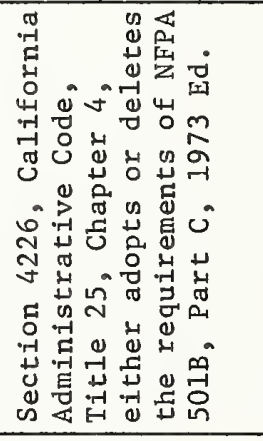 & 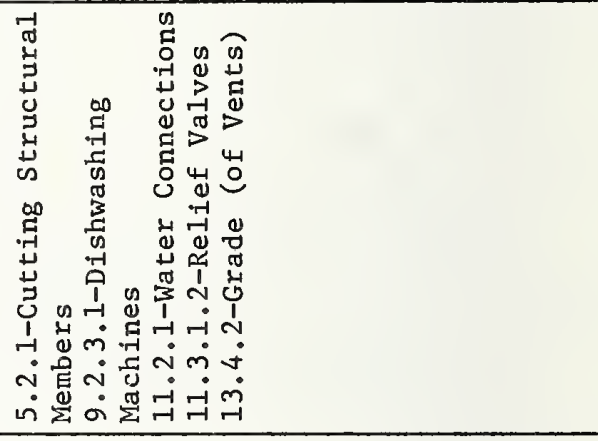 \\
\hline & & 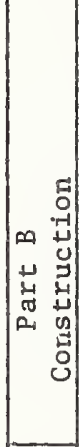 & 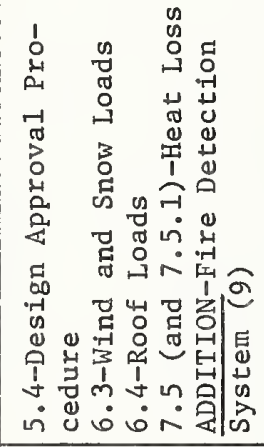 & 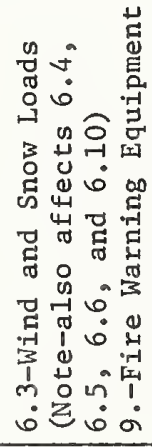 & 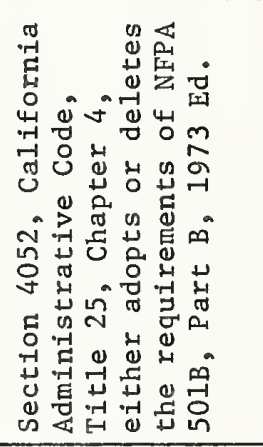 & 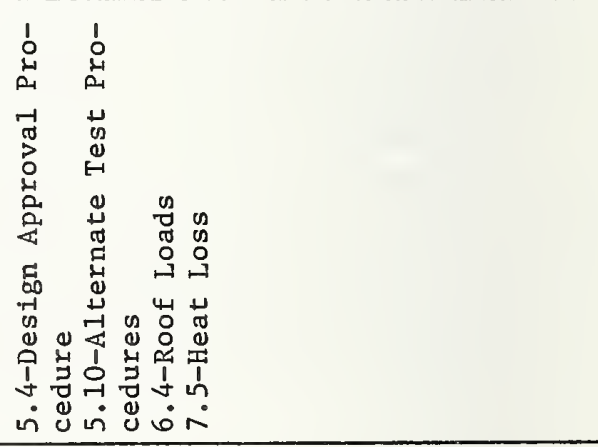 \\
\hline & & 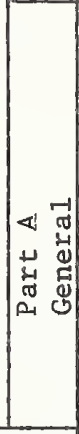 & & & 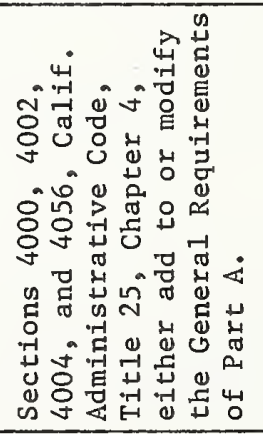 & \\
\hline & \multicolumn{2}{|c|}{ 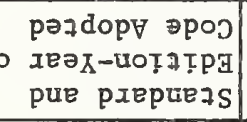 } & 붕 & 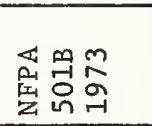 &  & 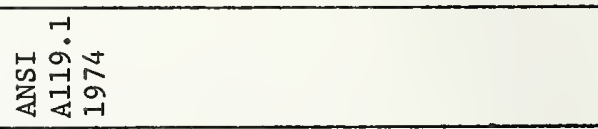 \\
\hline & & 站 & 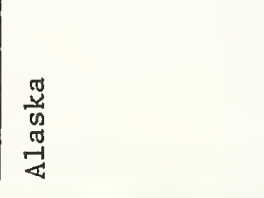 & 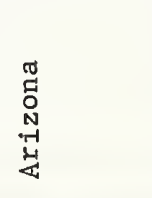 & 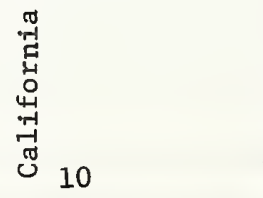 & 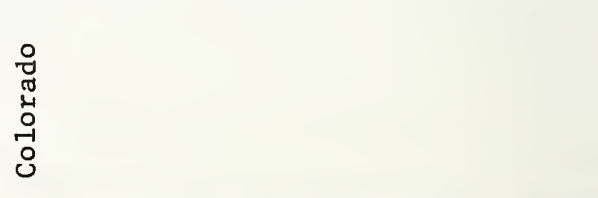 \\
\hline
\end{tabular}




\section{Analysis of Amendments--Compiled by Construction Discipline}

The provisions of the ANSI Standard are functionally organized into five major parts-i.e., Part A, General Information; Part B, Body and Frame Design and Construction Requirements; Part C, Plumbing Systems; Part D, Heating Systems; and Part E, Electrical System. As an expedient to analyzing the impact of the various amendments previously identified in sections 4 and 5 of this report, they have been rearranged so that each group of common State-adopted amendments can be compared directly with the corresponding requirement in existing editions of the basic standard. To accomplish this the comparisons will be indexed and presented according to the same functional organization as that provided in the ANSI Standard. This requires that the individual technical sections in each functional part be indexed, that the States with corresponding amendments be cross indexed to these, and that a reference be given where the specifics of the amendments and existing requirements can be presented. The following index serves as a directory for major parts of the ANSI Standard as they are presented in this section of the report.

\begin{tabular}{|c|c|c|c|c|c|c|c|c|c|c|}
\hline & & & & & & & & & & $\begin{array}{c}\text { Report } \\
\text { Page }\end{array}$ \\
\hline \multicolumn{11}{|l|}{ Part A-General } \\
\hline Index of State-Adopted Amendments & . • & • & - . & . & . $\cdot$ & - . & - & • & - & 16 \\
\hline Amendment Comparison Sheets . • & - $\cdot$ & $\cdot$ & - $\cdot$ & - & - $\cdot$ & - $\cdot$ & - & - & - & - $17-18$ \\
\hline \multicolumn{11}{|l|}{ Part B-Construction Requirements } \\
\hline Index of State-Adopted Amendments & . & . & . & - . & . & - . & - & . & . & . $19-21$ \\
\hline Amendment Comparison Sheets . $\cdot$ & - $\cdot$ & $\cdot$ & - $\cdot$ & $\cdot$ & $\cdot \cdot$ & - $\cdot$ & $\cdot$ & - & - & - $22-52$ \\
\hline \multicolumn{11}{|l|}{ Part C-Plumbing Systems } \\
\hline Index of State-Adopted Amendments & . & . & . . & . & . $\cdot$ & .. & . & . & . & . 53-59 \\
\hline Amendment Comparison Sheets $\cdot \cdot \cdot$ & - $\cdot$ & $\cdot$ & - $\bullet$ & $\cdot$ & $\cdot \cdot$ & - $\cdot$ & $\cdot$ & - & - & - $60-68$ \\
\hline \multicolumn{11}{|l|}{ Part D-Heating Systems } \\
\hline Index of State-Adopted Amendments & .. & & & & & & . & . & . & . $69-72$ \\
\hline Amendment Comparison Sheets $\cdot \cdot \cdot$ & & $\cdot$ & & • $\cdot$ & & & - & - & & - $73-80$ \\
\hline art E-E Lectrical & & & & & & & & & & \\
\hline Index of State-Adopted As & & - & & & & & & - & - & -84 \\
\hline Amendment Comparison Sheets . . . & & . & & & & & & & & . $85-88$ \\
\hline
\end{tabular}

Because of the extent of the deviations in the codes developed and adopted by the States of California and Washington, the index sheets contain separate columns which cross-reference the ANSI requirements to the corresponding requirements in the California and Washington codes.

The amendment comparison sheets are organized in such a manner that the applicable ANSI requirements from the 1974 and 1975 Editions are presented at the beginning of each amended section. The corresponding State-adopted amendments are then listed along with a reference to cite where the material was obtained.

\section{Part A-General}

The only interest in this part was to examine the extent of modifications to the definition of "mobile home" as it is given in the ANSI Standard. As indicated previously, four States--California, Ohio, Oregon, and Washington--have nade substantitive changes in the terminology. Other definitions of "mobile home" which do not affect the definitions in the ANSI Standard are given in appendix B. 


\section{Part B-Construction Requirements}

This is the part of the standard with the greatest number of State-adopted amendments-fifty-six of the one hundred nine that have been identified. Within this part, the following sections have been amended most often:

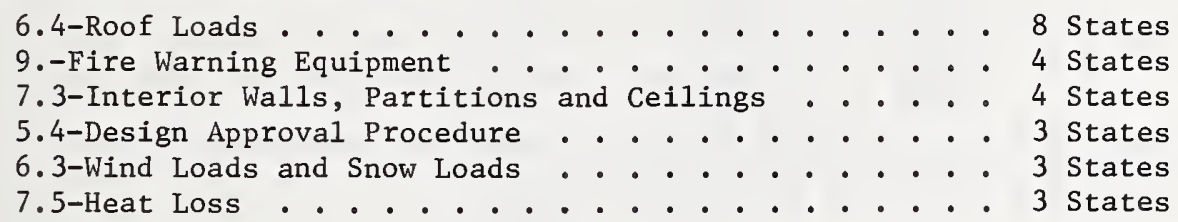

It was felt that three new additions be included within the section on general requirements even though they dealt primarily with regulatory matters. This includes requirements for serial numbers (5.11), data plates (5.12), and width limitations (5.13).

\section{Part C-Plumbing Systems}

Twenty-four amendments were made to Part C, seven of them to section 11.2 .1 on water connections. The only other section with more than one amendment was section 13.4 (from 1975 proposed edition of ANSI A119.1) dealing with Anti-Siphon Trap Vents.

The Reciprocity Committee of the National Conference of States on Building Codes and Standards (NCSBCS) has approved an amendment to section 11.2 .1 which apparently has been adopted in the amendments made by the States of Arizona, Colorado, Iowa, North Carolina, and Virginia.

\section{Part D-Heating Systems}

Seven States have made a total of sixteen amendments to Part D, Sections 5.1.12, Appliance Connections, and 5.1.14, Valves, were amended three times each by four neighboring States in the southwest part of the country--Arizona, Colorado, Nevada, and New Mexico.

\section{Part E-Electrical Systems}

Only nine amendments have been made to this part--four of them being classified as additions or restrictions to existing requirements. 

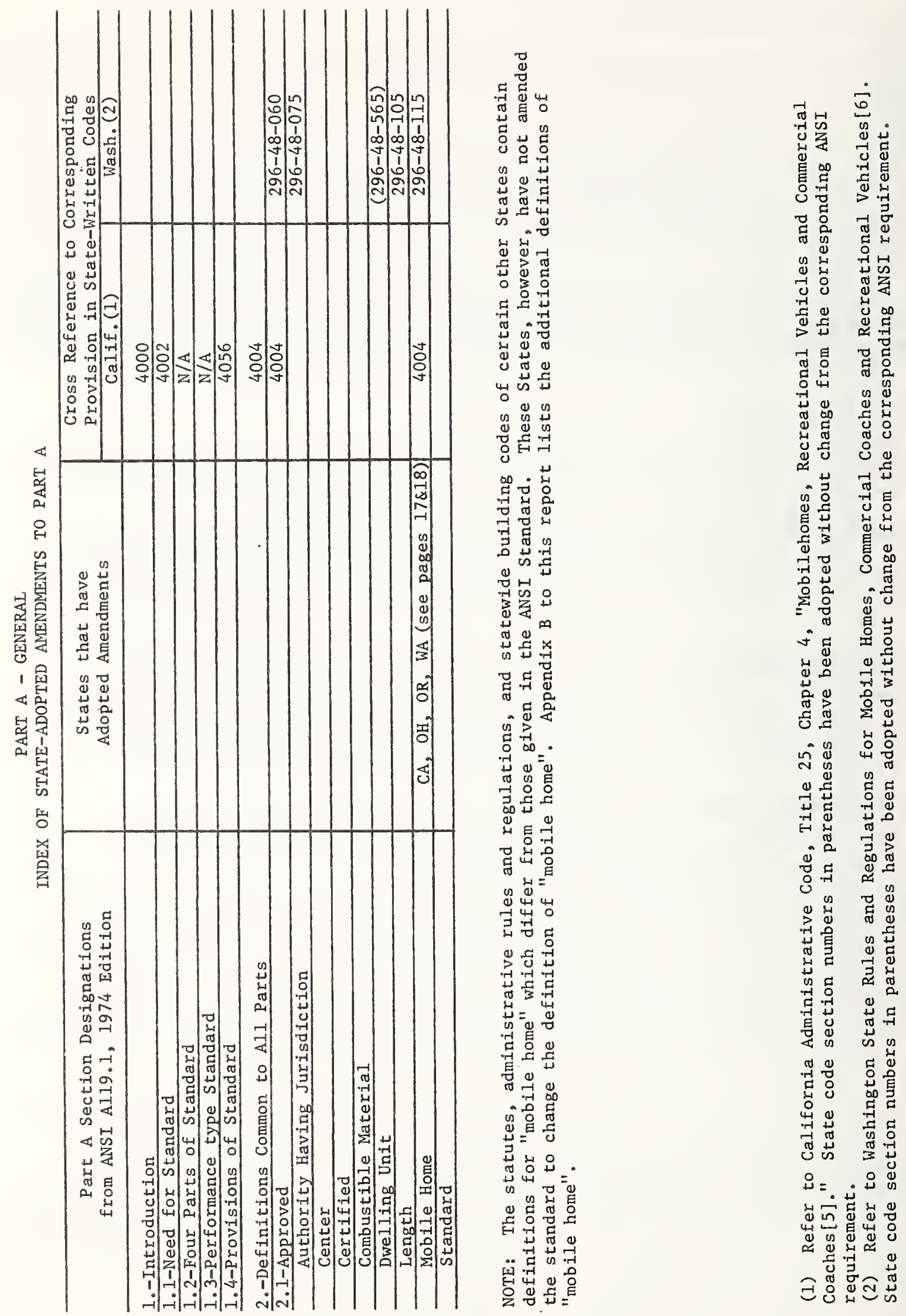
ANSI A119.1, $1974 \quad \& \quad 1975$

\subsection{Definitions Common to All Parts}

2.1 The following definitions are common to all Parts of this Standard. Additional definitions applicable to the individual Parts, are contained in each Part.

Mobile Home. A factory-assembled structure or structures equipped with the necessary service connections and made so as to be readily movable as a unit or units in it (their) own running gear and designed to be used as a dwelling unit(s) without a permanent foundation.

The phrase "without a permanent foundation" indicates that the support system is constructed with the intent that the mobile home placed thereon will be moved from time to time at the convenience of the owner.

\section{CA (STATE CODE)}

18008. "Mobilehome" is a vehicle designed and equipped to contain not more than two dwelling units to be used without a permanent foundation.

Ref: California Administrative Register 73, No. 36-B, Title 25, Housing and Community Development.

\section{OH (ANSI A119.1, 1974)}

"Mobile Home" means a movable or portable structure designed and constructed to be towed as a unit or units, on its or their own chassis and running gear, on the public streets or highways and designed, constructed and equipped with the necessary service connections for human occupancy and habitation as a "dwelling unit" whether resting on wheels, jacks or other supports (not enclosing a basement, cellar or crawl space) from which said structure(s) can be readily removed and transported.

(A) Single wide, double wide, dual or other multiple units placed on basements, cellars or crawl spaces are not considered readily mobile, and are subject to applicable $O B C$ industrialized unit regulations for specific occupancy or use;

(B) Mobile structures not intended for use as "dwelling units", or multistory mobile homes are subject to the applicable provisions of this chapter as well as applicable OBC regulations for specific occupancy or use;

(C) Mobile homes attached to or 4 feet less from any structure which creates a "mixed occupancy" as defined in BB-1-31 OBC shall comply with the provisions of section $\mathrm{BB}-21-11$ OBC.

Ref: Ohio Building Code, Ch. BB-77, Industrialized Units (Mobile Homes and Recreational Vehicles) Section $B B-77-01$.

OR (ANSI A119.1, 1973)

(16) "Mobile Home" means a vehicle or structure constructed for movement on the public highways, that has sleeping, cooking and plumbing facilities, is intended for human occupancy and is being used for residential purposes.

Ref: Department of Commerce, Oregon Administrative Rules, Ch. 814, Subdivision 3, Administration of Mobile Homes and Recreational Vehicles Law, Oregon Administrative Rules. 
WA (STATE CODE)

WAC 296-48-115 MOBILE HOME. All trailers of the type designed as facilities for human habitation which are capable of being upon the public streets and highways and which are more than 32 feet in length except as hereinafter specifically excluded.

Ref: Department of Labor and Industries, Mobile Home, Commercial Coach and Recreational Vehicle Section, Rules and Regulations for Mobile Homes, Commercial Coaches and Recreational Vehicles.

(Also see note on page 16) 


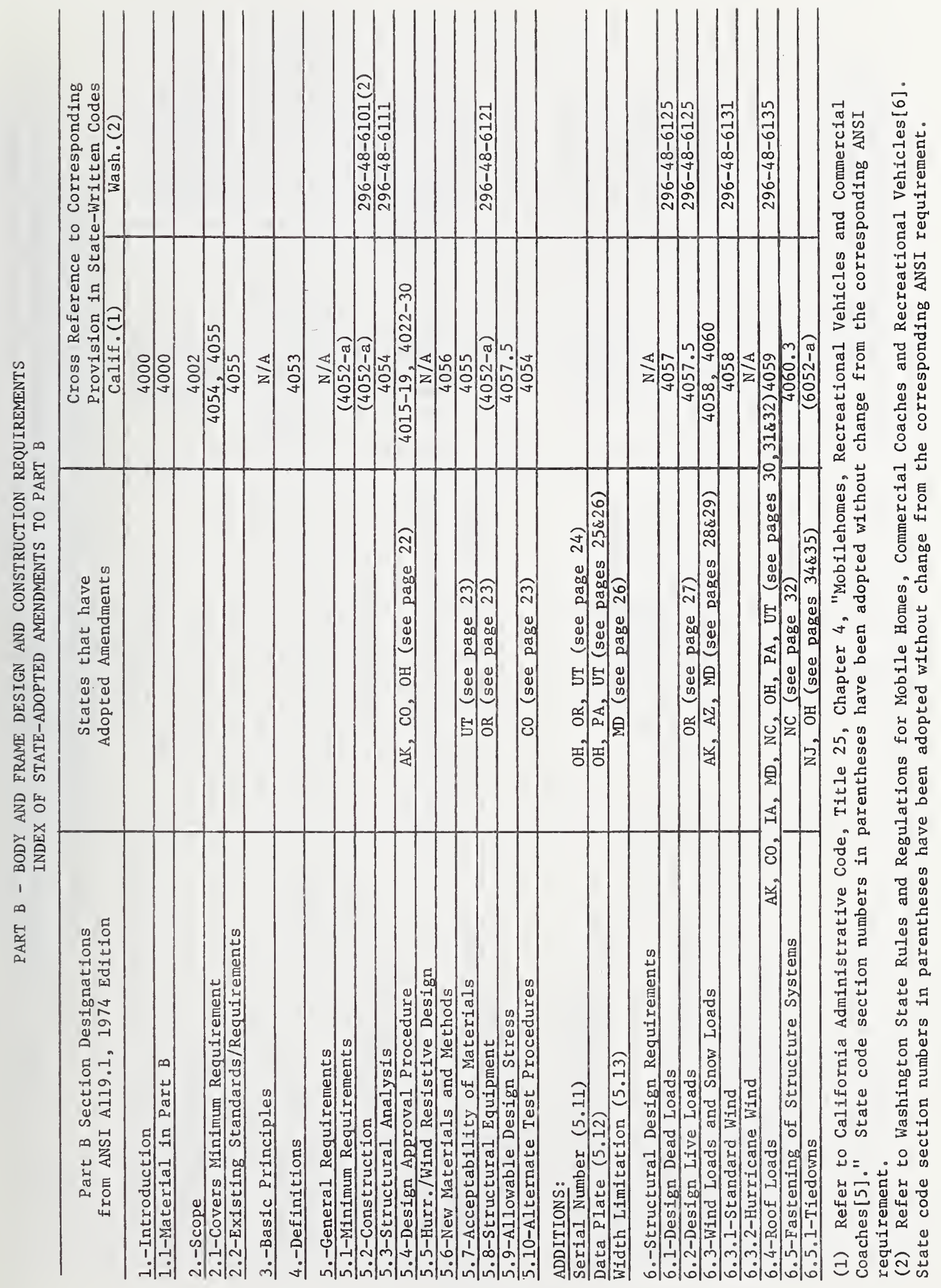




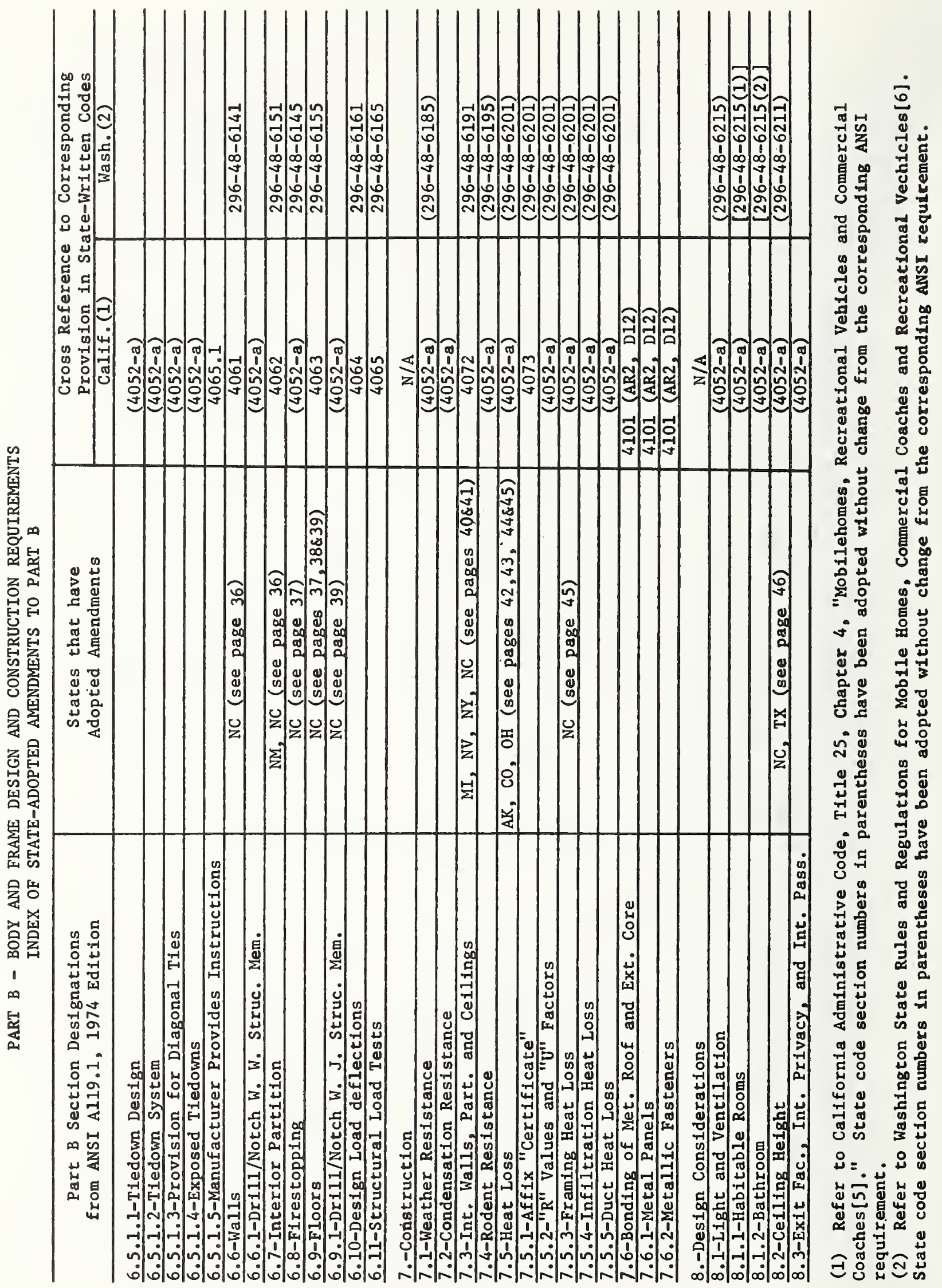




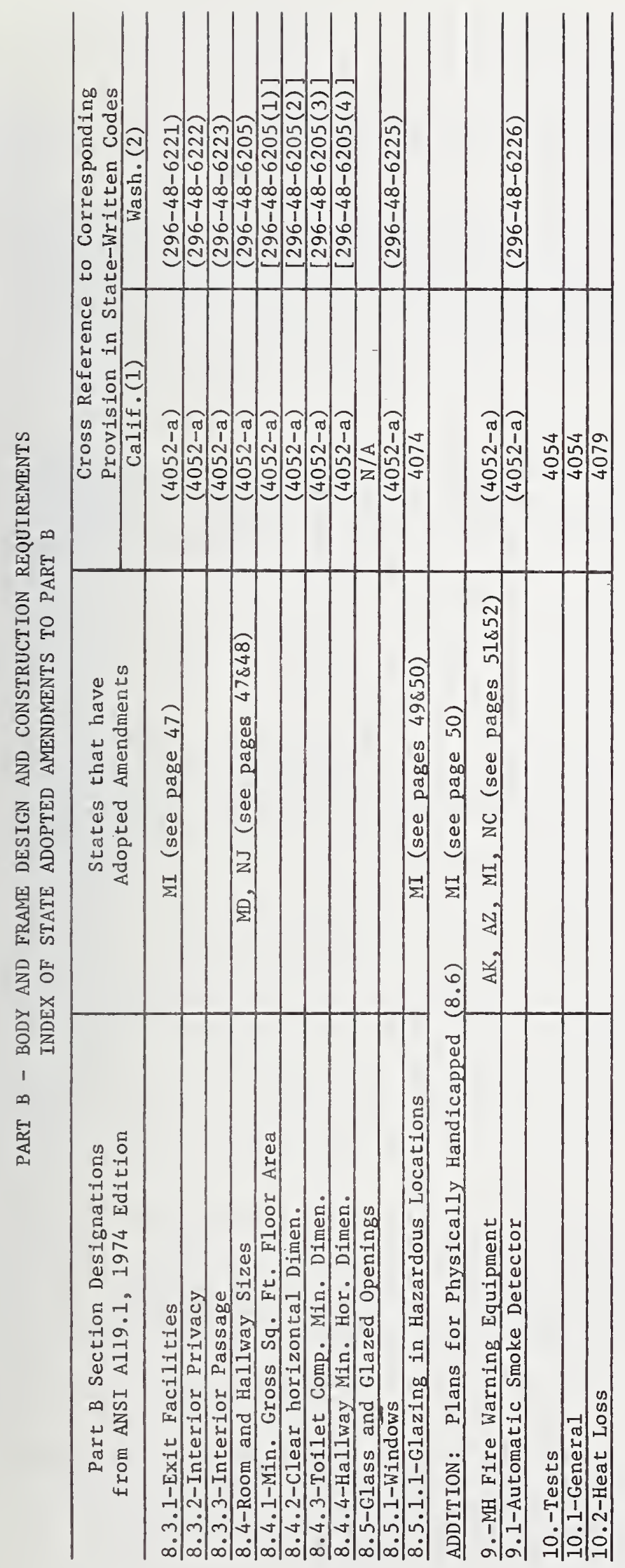

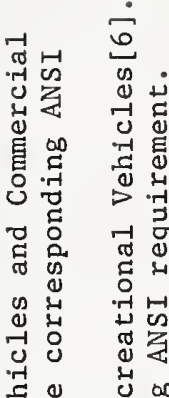

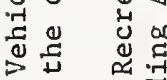

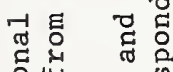

क

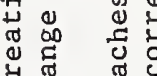

ช ठ ठ ठ

-

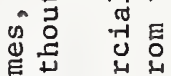

址

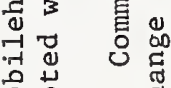



$=$ चु

งำ 옹

过

范

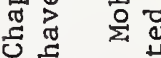

กิ

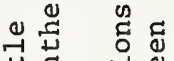

㟧

ज幽

ब

व. .

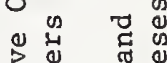

需的

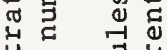

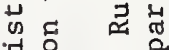

苛

毒进出

워 음

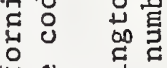

嵌岀 壳

告粦尔

$\dot{D}=$ 品

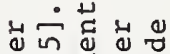

出的岁峲

త 


\subsection{Design Approval Procedure}

ANSI A119.1, $1974 \& 1975$

5.4 Design Approval Procedure. Approval of plans, specifications, and completed mobile homes by the authority having jurisdiction under the provisions of this Standard shall be accomplished by a certificate of compliance from a firm or organization having a qualified engineering staff acceptable to the authority having jurisdiction, or by a registered professional engineer or architect, or by a nationally recognized testing laboratory.

AK (ANSI A119.1, 1972)

(1) Paragraph 5.4 of Part B shall read:

"5.4 Design Approval Procedure. A certificate of compliance covering plans, specifications, calculations and construction requirements by a professional engineer or architect registered in the State of Alaska or a firm or organization or testing laboratory having a qualified engineering and/or testing staff acceptable to the Section of Weights and Measures is required. Ref: Chapter 36, Standards for Mobile Homes, Article 2, Construction Standards, April 1973.

CO (ANSI A119.1, 1974)

(1) Delete Section 5.4, Part B as written, and add as a new Section 5.4:

"Approval of plans, specifications, and completed mobile homes shall be accomplished by the authority having jurisdiction in accordance with their rules and regulations."

Ref: Notice of Adopting of Rules regarding Construction Standards; Colorado Division of Housing; December 19, 1974.

OH (ANSI Al19.1, 1974)

2. Paragraph 5.4, Part B, Design Approval Procedure, shall be amended to read:

"Approval of plans, specifications, and completed mobile homes by the board under provisions of this standard shall be accomplished by a certificate of compliance from an approved independent agency licensed by the board. The certificate of compliance becomes valid only after approval by the board;"

Ref: Ohio Building Code, Chapter BB-77, Industrialized Units (Mobile Homes and Recreational Vehicles) Section BB-77-05, Mobile Home Standards and Modifications.

\subsection{AcCeptability of Materials}

ANSI A119.1, 1975

5.7 Acceptability of Materials. The Appendix to this Part lists a group of Accepted Engineering Practice Standards which may be referred to for guidance. Deviations from the applicable portions of these Standards shall be permitted when they meet the performance requirements specified herein.

ANSI A119.1, 1974

5.7 Acceptability of Materials. Following the applicable provisions of the Standards listed in the Appendix of this Part, Table B-I (Accepted Engineering Practice Standards), except as otherwise prescribed in this Standard, shall constitute compliance. Deviations from applicable provisions of thses prescribed Standards (Table B-1) when they meet the performance requirements of this Standard shall constitute compliance. 
III-17 COMBUSTIBLE MATERIAL. Accepted use of polyurethane for the State of Utah, Mobile Home Division is polyurethane insulated sandwiched between C-flame spread paneling and aluminum siding, or sandwiched between two pieces of aluminum, or sandwiched between C-flame spread paneling and fiberglass or any other component similar to the above. Polyurethane in the following areas is not acceptable:

(1) All areas exposed, to the atmosphere;

(2) Used as an underseal or in wheel wells;

(3) Used in generator compartments;

(4) In storage compartments as a buffer situation on plumbing, and;

(5) When used on backing of all fixtures or compartments, unless it can be sandwiched securely between the exterior paneling and fixture, and floor area for supports. (Except upholstery material).

Ref: Utah Code, Title 4, Chapter 20, Mobile Homes, Travel Trailers or Recreational Vehicles.

\subsection{Structural Rf.quirements}

ANSI A119.1, $1974 \& 1975$

5.8 Structural Requirements. Each mobile home shall be designed and constructed as a complete integrated structure capable of sustaining the design load requirements of this Standard and shall be capable of transmitting these loads to stabilizing devices without causing an unsafe deformation or abnormal internal movement of the structure or its structural parts.

OR (ANSI A119.1, 1973)

23-910 Amendments to proposed ANSI A119.1(1973). (1) Part B, Section 5.8 Structural Requirements. Each mobile home shall be designed and constructed as a completely integrated structure capable of sustaining the design load requirements of this Standard and shall be capable of transmitting these loads to stabilizing devices without causing an unsafe deformation or abnormal internal movement of the structure or its structural parts. Each mobile home shall be equipped with all necessary bolts, beams, columns and other such structural components necessary to the design and shown on the plans approved by the enforcing authority.

Ref: Department of Commerce, Subdivision 3, Administration of Mobile Homes and Recreational Vehicles Law, Oregon Administrative Rules Sections 23-005 to 23-725.

\subsection{Alternate Test Procedures}

ANSI A119.1, 1974 \& 1975

5.10 Alternate Test Procedures. In the absence of 1isted and prescribed Standards, the manufacturer shall develop or cause to be developed necessary tests to demonstrate the structural properties and the significant characteristics of the method employed. Such tests shall be made either by a recognized testing organization or by a registered professional engineer or registered architect. Copies of the test results shall be kept on file by the mobile home manufacturer.

CO (ANSI A119.1, 1974)

(2) Delete Section 5.10, Part B and add:

"See Section 1.4, Part A, Page 10."

Ref: Notice of Adopting of Rules Regarding Construction Standards; Colorado Division of Housing; December 19, 1974. 
ANSI A119.1, $1974 \& 1975$

NO PROVISION

OH (ANSI A119.1, 1974)

6. The serial number of the mobile home is required to be stamped (die set) on the structural chassis.

Ref: Ohio Building Code, Chapter BB-77, Industrialized Units (Mobile Homes and Recreational Vehicles) Section BB-77-05, Mobile Home Standards and Modifications.

OR (ANSI A119.1, 1973)

23-235 VEHICLE IDENTIFICATION. (1) Each mobile home and recreational vehicle manufactured, rented, leased or sold or offered for rent, lease or sale in Oregon shall bear a legible identifying serial number which shall be prefaced by the letter "S" and shall have no other numbers, letters or symbols included other than an $\mathrm{X}$ or $\mathrm{U}$ as required by this section. Each vehicle shall also bear an identification plate which shall include the name and address of the manufacturer, date of manufacture, serial number and where applicable, the plan approval number. When the date of manufacture is coded, the enforcing agency shall be informed of the method of coding.

(2) The serial number shall be stamped in a visible location on the front cross member or tongue. Each unit of a multiple mobile home shall have the same identifying serial number, except that the serial number of primary or left (road) side unit shall be followed by a "U". The serial number of the first connecting unit shall be followed by an " $\mathrm{X}$ " and an additional "X" shall be added for each succeeding unit. Exception: The manufacturer may designate another location for the serial number acceptable to the enforcing agency.

(3) The identification plate shall be permanently attached to the exterior wall adjacent to the main door and not less than six (6) inches above the floor line. The identification plate shall be made of etched brass, stainless steel, anodized or alclad aluminum not less than 0.020 inch thick or other approved material, three inches by one and three quarters inches minimum size with lettering not less than one-eighth inch high.

Ref: Department of Commerce, Subdivision 3, Administration of Mobile Homes and Recreational Vehicles Law, Oregon Administrative Rules, Sections 23-005 to 23-725.

\section{UT (NFPA 501B, 1973)}

IV-12 VEHICLE IDENTIFICATION. Each vehicle manufactured, rented, leased, sold, or offered for sale in the State of Utah shall bear a legible identifying VIN (Vehicle Identification Number) permanently stamped on the vehicle tongue (hitch) unless stamped as in Exception (1) below. The serial number designations shall be in compliance with the Utah State Department of Motor Vehicle Business Administration Regulation \#3-10, as amended.

EXCEPTION: (1) If the vehicle tongue which is designed to be removed, the VIN must be stamped on a permanent cross member of the frame adjacent to the tongue, if located to be visible at all times.

(a) All manufacturers shall furnish the Department a detailed breakdown of the coding of VIN numbers prior to shipping units into the State.

Ref: Utah Code, Title 4, Chapter 20, Mobile Homes, Travel Trailers or Recreational Vehicles. 


\begin{tabular}{|l|}
\hline ANSI AII9.1, $1974 \& 1975$ \\
\hline NO PROVISION
\end{tabular}

OH (ANSI A119.1, 1974)

BB-77-07. Data Plate and Other Markings.

(A) A permanent Data Plate shall be located near the main electrical panel or other readily accessible location in accordance with the terms of the authorization.

(B) The Data Plate shall contain at least:

(1) "Mobile homes (or recreational vehicles) bearing a (agency name or trademark) label with the words 'Listed (or other appropriate word in accordance with ANSI Mobile Home Standard Al19.1-74' (or ANSI Recreational Vehicle Standard Al19.2-73) means that (agency name or trademark) has evaluated, tested and inspected representative mobile homes (or recreational vehicles) or the manufacturer and established follow-up inspections consisting of making structural (for mobile homes only), plumbing, heating, or electrical inspections on each unit labeled;"

(2) Manufacturer's name and address and plant of origin of unit;

(3) Serial number of label, serial and model number of unit, model year of unit, and date label was affixed (these items should have a blank where information may be written in for each unit);

(4) The following items shall be listed on the mobile home Data Plate as stated:

"Conditions for Acceptance of ANSI Mobile Home Standard Al19.1-74."

(a) "Plans, specifications and designs including structural calculations required under Section 5.4, Part B have been confirmed by (Name of Labeling Agency)

(b) "Alternate test procedures authorized by Section 5.0 and 10.1, Part B have been witnessed and verified by

(Name of Labeling Agency)

(c) "Tiedown provisions on the unit itself and the instructions for the entire tiedown and ground anchorage system as required by 6.5.1.5, Part B have been confirmed by (Name of Labeling Agency)

(d) "The calculations for the outdoor design temperature stated on the heat loss certificate furnished by the manufacturer as required under Sections 7.5 and 10.2 , Part $B$ have been confirmed by (Name of Labeling Agency)

(e) Zone Map--The required Zone Map shall be permanently affixed to the home with a statement indicating the Zone(s) the home is designed for.

(5) Factory installed Equipment--Manufacturer's name and model designation of major factory-installed appliances shall be included on the data plate. In addition, instructions for locating information on set up and installation of double wide units, expandable rooms, etc., shall be included; appliances;

(6) Gas Supply Connection Markings--Identifies type of gas and cautions users to check 
(7) Electrical Ratings--For single or multiple cord entrance and outdoor receptacle outlets to energize heating and/or air conditioning equipment.

(C) The other markings shall be as required by ANSI A119.1 or ANSI Al19.2 for mobile homes and recreational vehicles respectively.

Ref: Ohio Building Code, Chapter $B B-77$, Industrialized Units (Mobile Homes and Recreational Vehicles) Section $B B-77-07$.

\section{PA (ANSI A119.1, 1974)}

7.62 Data Plates. (a) Each certified mobile home dwelling unit shall contain a data plate, as illustrated on Figure 7.1 (see page 1040). The data plate shall be furnished by the Department and shall be permanently attached by the manufacturer in the area of the electric utility box, if feasible, or otherwise in such an area as identified in the building system documentation. All applicable information contained on the data plate should be completed by the manufacturer before the attachment of such data plate to mobile home units.

Ref: Department of Community Affairs, (16 Pennsylvania Code, Chapter 7) Uniform Standards for Mobile Homes.

UT (NFPA 501B, 1973)

Manufacturer's data plate. A manufacturer's data plate posted inside a cabinet or near distribution panel on all new mobile homes manufactured after April 1, 1974, which shall contain the following information:

(1) Manufacturer model and serial numbers.

(2) Month and year of manufacture.

(3) Heat loss certificate.*

(4) Roof and wind loads for North Zone. $* *$

(5) A listing of manufacturer installed appliances stating appliance manufacturer and model.

(6) Calculated load - amps; 120/240 volts, three pole, four wire, 60 hertz.

*as required by the standard in effect at time of manufacture (Ref. 501B, 1973, Part B, Section 7.5 .1 or as amended.)

**as required by the standard in effect at time of manufacture (Ref. 501B, 1973, Part B, Section 7.5 .1 or as amended.)

(7) Utah State insignia number.

Ref: Utah Code, Title 4, Chapter 20, Mobile Homes, Travel Trailers or Recreational Vehicles.

\subsection{WIDTH LiMITATION}

ANSI A119.1, $1974 \& 1975$

NO PROVISION

MD (ANSI A119.1, 1974)

Expandable mobile homes, including push-outs, tip-outs, etc., may be constructed in accordance with NFPA 501-1971 Standard for Mobile Homes if they are designed so that the expandable portion of a home does not exceed one third of its unexpanded floor area. Ref: Maryland Department of Economic and Community Development, Codes Administration, Information Bulletin No. 4, January 1973. 
ANSI A119.1, $1974 \& 1975$

6. Structural Design Requirements

6.1 Design Dead Loads. Design dead loads shall be the actual dead load (see 4.8 .1 of this Part) supported by the structural assembly under consideration.

6.2 Design Live Loads. The design live loads shall be as specified in 6.3, 6.4, 6.6, 6.9, 6.10 , and 6.11 of this Part and shall be considered to be uniformly distributed. The roof live load shall not be considered as acting simultaneously with the wind load and the roof and floor live loads shall not be considered as resisting the overturning moment due to wind.

\section{CA (STATE CODE)}

4060.1. Posting Design Loads. The manufacturer shall post the loads the mobile home has been designed for as follows:

Roof Live Load . . . . . . . . . . . . . . . . . . . psf

Wind Load . . . . . . . . . . . . . . . . . . . . - 1 psf

These loads shall be included on the manufacturer's certificate (see Section 4073) which shall be affixed to an interior surface on the mobile home and shall be readily visible. Design loads shall also be posted on the exterior of the mobile home. The design loads shall be shown on a label securely affixed to the rear of the vehicle on the lower left hand corner of the exterior wall not less than six inches (6") above the floor line or on the exterior wall immediately adjacent to the main door not less than six inches ( $6^{\prime \prime}$ ) above floor line.

NOTE: See Article 1, Section 4031 for label size and type of material.

4057.5 Design Live Loads. The design love loads shall be as specified in Sections 4058 , $4059,4060,4061,4063,4064$, and 4065 and shall be considered to be uniformly distributed. The roof live load shall not be considered as acting simultaneously with the wind load and the roof and floor live loads shall not be considered as resisting the overturning moment due to wind.

Ref: California Administrative Register 73, No. 36B, Title 25, Housing and Community Development.

OR (ANSI AI19.1, 1973)

(2) Part B, Section 6.2 Design Live Load. The design live loads shall be as specified in $6.3,6.4,6.6,6.9,6.10$, and 6.11 of this Part and shall be considered to be uniformly distributed. The roof live load shall not be considered as acting simultaneously with the wind load and the roof and floor live loads shall not be considered as resisting the overturning moment due to wind. In addition, interior walls shall be capable of withstanding a horizontal load of not less than five (5) pounds per sqare foot.

Ref: Department of Commerce, or Administrative Rules, Chapter 814, Subdivision 3, Administration of Mobile Homes and Recreational Vehicles Law.

\subsection{Wind AND SNOW LOADS}

ANSI AI19.1, 1975

6.3. Wind and Snow Loads.

6.3.1 Standard Wind. When a mobile home is not designated "Hurricane- and WindstormResistive," the mobile home shall be designed for the following wind loads: 
Horizontal ........................ $15 \mathrm{lb} / \mathrm{ft}_{2}^{2}$ (1 day load duration)

Vertical Upward ............. 9 lb/ft ${ }^{2}$ (1 day load duration)

Vertical Downward ......................... See 6.4, Roof Loads)

6.3.2 Hurricane Wind. When a mobile home is designated "Hurricane- and WindstormResistive," the mobile home shall be designed for the following wind loads:

Horizontal .................. $25 \mathrm{lb} / \mathrm{ft}_{2}^{2}$ (1 day load duration)

Vertical Upward ........... $15 \mathrm{lb} / \mathrm{ft}^{2}$ (1 day load duration)

Vertical Downward .............................. Ree 6.4, Loads)

ANSI A119.1, 1974

6.3 Wind Loads and Snow Loads. When one of the components of the live load is wind or snow load, unit stresses may be increased in accordance with the applicable Accepted Engineering Practice Standards listed in Table B-1.

\subsubsection{Standard Wind.}

Horizontal ............................ $15 \mathrm{Ib} / \mathrm{ft}_{2}^{2}$

Vertical (horizontal projection).............. $9 \mathrm{~b} / \mathrm{ft}^{2}$ uplift

Vertical Downward ........................ 6.4 Roof Loads

6.3.2 Hurricane Wind. When a mobile home is designated "Hurricane- and WindstormResistive," the mobile home itself shall be designed for the following wind loads:

Horizontal ..................... $25 \mathrm{lb} / \mathrm{ft} \mathrm{t}_{2}^{2}$

Vertical (horizontal projection) . . . . . . $15 \mathrm{lb} / \mathrm{ft}^{2}$ uplift

Vertical Downward ............................ 6.4 Roof Loads

AK (ANSI A119.1, 1972)

(2) Paragraph 6.3 of Part B shall read:

"6.3. Wind and Snow Loads. The amount of live load shall not be less than the amounts specified in this paragraph. No increase in unit stresses shall be permitted.

6.3.1 Standard Wind.

Horizontal ................. $20 \mathrm{lb} / \mathrm{ft}_{2}^{2}$

Vertical (horizontal projection) .......... $12 \mathrm{lb} / \mathrm{ft}_{2}^{2}$ uplift

Vertical Downward (see 6.4 Roof Loads) ........ $30 \mathrm{lb} / \mathrm{ft}^{2}$

6.3.2 Hurricane Wind. Mobile homes which are designated "Hurricane- and WindstormResistive" shall be designed for the following wind loads:

Horizontal ............... $25 \mathrm{lb} / \mathrm{ft}_{2}^{2}$

Vertical (horizontal projection) .................. $15 \mathrm{lb} / \mathrm{ft}_{2}^{2}$ uplift

Vertical Downward (see 6.4 Roof Loads) . . . ... $30 \mathrm{lb} / \mathrm{ft}^{2}$

6.3.3 Snow Loads. Flat, curved, and pitched roofs shall be designed to resist a minimum snow load applied downward on the horizontal projection of $30 \mathrm{lb} / \mathrm{ft} \mathrm{t}^{2}$."

Ref: Chapter 36, Standard for Mobile Homes, Article 2, Construction Standards, April 1973.

\section{AZ (NFPA 501B, 1973)}

All manufacturers shall include as an integral part of each mobile home such tie-down requirements as set forth in ANSI Al19.1, 501B, 1973, Section 6.3.1 through and including 6.10 as amended, and shall conform to Middle Zone: $20 \mathrm{lb} / \mathrm{ft}^{2}$ (including wind and snow loads), or shall have structural calculations and stress analysis by a licensed professicnal 
engineer or architect certifying that such loads are equal to or exceed these requirements and shall have posted by label within the interior of the mobile home adjacent to the main circuit breaker that such standards have been met. Directions for tie-downs supplied by the manufacturer must accompany all mobile homes as per Section 6.5, ANSI A119.1.

Ref: Division of Building Codes; Rules, Regulations, and Standards, Title 44, Chapter 11, Article 7 .

\section{CA (STATE CODE)}

4058. Wind Loads. Mobile homes shall be designed to withstand minimum horizontal and uplift pressures from any direction as follows:

Horizontal . . . . . . . . . . . . . . . . $151 \mathrm{~b} / \mathrm{ft}_{2}^{2}$

Vertical (horizontal projection)............ . $91 \mathrm{l} / \mathrm{ft}^{2}$ uplift

Unit stresses may be increased in accordance with the applicable Accepted Engineering Practice Standards listed in Table B-1, Appendix MH.

4060. Snow Loads. Where it is known that the mobile home will be subjected to snow loads, the mobile home shall be designed for the appropriate loads. Unit stresses may be increased in accordance with applicable accepted Engineering Practice Standards 1isted in Table B-1, Appendix MH.

Ref: California Administrative Register 73, No. 36-B, Title 25, Housing and Community Development.

\section{MD (ANSI A119.1, 1974)}

Design Loads.

To clarify and re-cap previous rulings on required roof and wind loads (See Bulletins 非 4 非), all mobile homes and industrialized buildings must meet the following design criteria to qualify for acceptance by this office:

Roof Live Load . . . . . . . . . . . . . . . . . . . 30 psf Horizontal Wind Load . . . . . . . . . . . . . . . . . . 25 psf

The design roof load required is based on the fact that all of Maryland is subject to snow load, and the wind load is due to the fact that most of the State is in the Hurricane Zone. This ruling applies to all approved units, some of which were approved prior to the above rulings. All Approved Testing Facilities and Manufacturers are required to check for conformance to the above. These requirements are effective immediately but cases of hardship will be considered if submitted immediately.

Ref: Maryland Department of Economic and Community Development, Codes Administration, Information Bulletin No. 7, June 1973.

\subsection{ROOF LOADS}

ANSI A119.1, 1975

6.4. Roof Loads. Flat, curved, and pitched roofs shall be designed to resist the following live loads, applied downward on the horizontal projection:

North Zone................. . . $30 \mathrm{lb} / \mathrm{ft}_{2}^{2}$ (2 months load duration)

Middle Zone ................. . . $20 \mathrm{lb} / \mathrm{ft}_{2}^{2}$ (7 days load duration)

Hurricane Zone............... . . $30 \mathrm{lb} / \mathrm{ft}^{2}$ (1 day load duration)

NOTE: When engineering calculations are performed, allowable unit stresses may be increased as provided in the documents referenced in the Appendix Table to Accepted Engineering Practice Standard consistent with the load durations specified in Paragraphs 6.3 and 6.4 of this Part. 
The Manufacturer's Certificate posted in the mobile home (Paragraph 7.5 .1 of this Part) shall show for which structural zone(s) of the U.S.A. the mobile home has been designed and the actual design external snow and/or wind live loads. The Certificate shall include a reproduction of the Load Zone Map shown in the Appendix to this Part, and related information. The Load Zone Map shall not be less than one-half the size illustrated.

\section{ANSI A119.1, 1974}

6.4 Roof Loads. Flat, curved and pitched roofs shall be designed to resist the following live loads, applied downward on the horizontal projection:

North Zone: $\quad 30 \mathrm{lb} / \mathrm{ft}_{2}^{2}$ (including wind and snow loads)

Middle Zone: $20 \mathrm{lb} / \mathrm{ft}_{2}^{2}$ (including wind and snow loads)

Hurricane Zone: $30 \mathrm{lb} / \mathrm{ft}^{2}$ (including wind and snow loads)

See Appendix to this Part, Figure B-2, for Zone Map of U.S.A.

NOTE: Stresses may be increased as provided in the documents referenced in Table B-1.

The Manufacturer's Certificate posted in the mobile home (Paragraph 7.5.1 of this Part) shall show for which structural zone(s) of the U.S.A. the mobile home has been designed and the actual design erternal snow and/or wind live loads. The Certificate shall include a reproduction of the Zone Map shown in Figure B-2, Appendix to this Part, and related information. The Zone Map shall be not less than one-half the size illustrated.

\section{AK (ANSI AI19.1, 1972)}

(3) Paragraph 6.4 of Part B shall read:

"6.4 Roof Loads. a. Flat, curved, and pitched roofs shall be designed to resist live loads, applied downward on the horizontal projection of $30 \mathrm{lb} / \mathrm{ft}^{2}$ including wind and snow loads as designated in paragraph 6.3 of this Part. No increase in unit stresses may be taken.

b. The Manufacturer's Certificate posted in the mobile home (paragraph 7.5 .1 of this Part) shall state that the mobile home has been designed for the structural requirements set out in paragraph 6.3 of this Part and this paragraph."

Ref: Chapter 36, Standard for Mobile Homes; Article 2, Construction Standards, April I973.

\section{CA (STATE CODE)}

4059. Roof Loads. Flat, curved, and pitched roof members shall be designed to sustain all loadings as follows:

(1) All dead loads plus a minimum unit live load of $201 \mathrm{~b} / \mathrm{ft}^{2}$

(2) A vertical uplift load of $91 \mathrm{~b} / \mathrm{ft}^{2}$

Ref: California Administrative Register 73, No. 36-B, Title 25, Housing and Community Development.

\section{CO (ANSI A119.1, 1974)}

(17) Add to Section 6.4, Part B:

"Minimum design live load for a roof on a mobile home to be sold or offered for sale in Colorado shall be $30 \mathrm{lb} / \mathrm{ft}^{2}$.

The manufacturer shall stamp the design load for each mobile home on the Division of Housing Mobile Home Certification Seal affixed to each mobile home."

Ref: Notice of Adoption of Rules Regarding Construction Standards; Colorado Division of Housing; December 19, 1974. 


\section{IA (ANS I A119.1, 1974)}

1) Add to 6.4 of Part B - All factory-built structures which are constructed to this standard and bear an Iowa seal shall be designed for the north zone.

Ref: Iowa State Building Code, Administrative Section, (1-14) June 1, 1974.

MD (ANSI A119.1, 1974)

Mobile Home Roof Loads.

There has been some question on the part of manufacturers concerning the requirements for roof loads as applied in the State of Maryland. Mobile homes are required to provide for roof loads as described in Section 6.4 of Al19.1 and the accompanying zone map in Figure B-2. The hurricane zone extends across the State of Maryland with all but the three western counties included. The western counties are in an area of frequent heavy snow which requires a $30 \mathrm{lb}$. per sq. ft. snow load. Accordingly, for uniformity, all mobile homes to be sold in the State of Maryland must be designed to support a $30 \mathrm{lb}$. per sq. ft. live load on their roofs.

Ref: Maryland Department of Economic and Community Development, Codes Administration, Information Bulletin.

NC (ANSI A119.1, 1974)

Figure B-2 - Weather Zone Map - Change to read as follows:

"ALL MOBILE HOMES MANUFACTURED AFTER OCTOBER 1, 1973 AND OFFERED FOR SALE IN ALL COUNTIES LISTED BELOW MUST MEET THE HURRICANE ZONE REQUIREMENTS:

\begin{tabular}{lllll} 
Beaufort & Chowan & Gates & Martin & Pender \\
Bertie & Columbus & Green & New Hanover & Perquimans \\
Brunswick & Craven & Hyde & Onslow & Pitt \\
Camden & Currituck & Jones & Pamlico & Tyrrell \\
Carteret & Dare & Lenoir & Pasquotank & Washington" \\
Ref: North Carolina State Building Code Council, adoption of "State of North Carolina \\
\multicolumn{2}{r}{ Standards for Mobile Homes" with amendments; [ANSI Al19.1-74 (NFPA B-73) adopted } \\
March 12, 1974].
\end{tabular}

OH (ANSI A119.1, 1974)

3. Paragraph 6.4, Roof Loads - For the purpose of this chapter the entire State of Ohio shall be considered to be in the North Zone for roof load calculations;

Ref: Ohio Building Code, Chapter BB-77, Industrialized Units (Mobile Homes and Recreational Vehicles) Section BB-77-05, Effective July I, 1974.

PA (ANSI A119.1, 1974)

$\underline{\text { Standards }}$

7.4.1 Adoption of standards and obtaining copies. The Department shall adopt ANSI Al19.1, 1974 unchanged, except for Figure B-2, "Weather Zone Map of the United States of America," which shows all three zones contained within Pennsylvania borders. It shall be required that all units built for sale in any part of Pennsylvania satisfy, as a minimum, the "North Zone" requirements. The ANSI A119.1 Standard is also known as NFPA 501B, 1973. The Standard is sponsored by and may be obtained from:

Ref: Department of Community Affairs, (16 Pennsylvania Code, Chapter 7), Uniform Standards for Mobile Homes. 


\section{UT (ANSI A119.1, 1973)}

II-30 Roof Loads. Flat, curved, and pitched roofs shall be designed to resist the following

live loads, applied downward on the horizontal projection:

North Zone: $30 \mathrm{lb} / \mathrm{ft}^{2}$ (Including wind and snow loads)

Ref: Utah Code Annotated 1953, Amended; Title 41, Chapter 20, Mobile Homes, Trailers, and Recreational Vehicles.

\subsection{Fastening of Structural Systems}

ANSI A119.1, 1975

6.5 Fastening of Structural Systems. Roof framing shall be securely fastened to wall framing, walls to floor structure, and floor structure to chassis to secure and maintain continulty between the floor and chassis, so as to resist wind overturning and sliding as imposed by design loads in 6.3 of this Part. (Directions for anchorage shall accompany all mobile homes.)

ANSI A119.1, 1974

6.5 Fastening of Structural Systems. Roof framing shall be securely fastened to wall framing, walls to floor structure, and floor structure to chassis to secure and maintain continuity between the floor and chassis, so as to resist wind overturning and sliding as imposed by design loads in 6.3.1 of this Part. (Directions for anchorage shall accompany ali mobile homes.)

NC (ANSI A119.1, 1974)

SECTION $6.5--F A S T E N I N G$ OF STRUCTURAL SYSTEMS

There must be a 20 gauge corrosion resistant metal strap $1.1 / 2^{\prime \prime} \times 12^{\prime \prime}$ fastening the wood stud to the roof joists and to the floor joist system every other stud or other methods of fastening as designed by a registered architect or registered engineer.

Roof joist systems and floor joist systems not designed by a registered architect or registered engineer in accordance with USAS-A119.1 must use the following specification requirements taken from the North Carolina Residential Code which is based on the same standards adopted by Al19.1.

Wood Construction--General.

All members shall be framed, anchored, tied, and braced to develop the strength and rigidity necessary for the purposes for which they are used.

Preparation, fabrication, and installation of wood members, connectors and mechanical devices for the fastening thereof, shall conform to accepted standards of good workmanship.

For those structural design requirements not covered herein, the "National Design Specification for Street-Grade Lumber and Its Fastenings," National Forest Products Association, shall be accepted as good practice.

The details specified hereln are applicable to conventional arrangements of wood framing. other methods may be used where adequacy has been established by engineering calculations or by structural tests. (Section 19(1) of Residential Code)

Grade Marking of Lumber.

Al1 lumber used for load aupporting purporer shall be identffied by the grade mark of a lumber grading or 1nspection bureau or agency approved by the Board of Review of the 
American Lumber Standards Committee. Lumber that is treated, rough sawn, or pre-cut and lumber thicker than two inches may be identified by a certificate of inspection from an approved inspection bureau of agency in lieu of grade marking. (Section 19(4) of Residential Code)

Ref: State of North Carolina, Regulations for Mobile Homes, 1972 Edition.

\section{5,1 TIEDOWNS}

ANSI A119.1, 1975

6.5 Fastening of Structural Systems. Roof framing shall be securely fastened to wall framing, walls to floor structure, and floor structure to chassis to secure and maintain continuity between the floor and chassis, so as to resist wind overturning and sliding as imposed by design loads in 6.3 of this Part. (Directions for anchorage shall accompany all mobile homes.)

6.5.1 Tiedowns. All mobile homes shall have tiedowns with provisions for distributing the load of these tiedowns and proviston for the attachment to ground anchors so as to resist wind overturning and sliding as imposed by the respective design loads of this Part.

Note No. 1. The provisions of Paragraphs 6.5.1.1, 6.5.1.2, and 6.5.1.3 of this Section shall be followed except when the tiedown system is designed by a Registered Professional Engineer or Architect.

Note No. 2. The manufacturer is only required to make provision for the connection(s) of tiedown hardware equipment but is not required to provide such equipment.

6.5.1.1 Each tiedown shall be designed to resist an allowable working load equal to or exceeding 3,150 pounds and shall be capable of withstanding a 50 percent overload without failure.

6.5.1.2 Unless the tiedown system is designed by a Registered Professional Engineer or Architect, tiedowns shall be placed as follows:

(a) Hurricane Zones. Not more than 12 feet on centers beginning from the front wall (first stud and/or first cross member). Not more than 6 feet open-end spacing shall be provided at the rear wall of the mobile home unless additional tiedowns are installed.

(b) Nonhurricane Zones. Not more than 24 feet on centers beginning from the front wall (first stud and/or first cross member). Not more than 6 feet open-end spacing shall be provided at the rear wall of the mobile home unless additional tiedowns are installed.

6.5.1.3 Provision for diagonal ties between ground anchors and the mobile home shall be made in conjunction with each vertical tiedown.

6.5.1.4 Tiedowns exposed to weathering shall be resistant to weathering deterioration at least equivalent to that provided by a coating of zinc on steel of not less than 0.30 ounces per square foot of surface coated.

Note: Type 1, Class B, Grade 1, steel strapping $11 / 4$ inches wide and 0.035 inch thick, conforming with Federal Specification QQ-S-781-F, is judged to conform with Paragraphs 6.5.1.1 and 6.5.1.4 of this Part.

6.5.1.5 The manufacturer shall provide printed instructions with each mobile home specifying the location and required capacity of stabilizing devices (tiedowns, piers, blocking, etc.) on which the design is based.

ANSI A119.1, 1974

6.5 Fastening of Structural Systems. Roof framing shall be securely fastened to wall framing, walls to floor structure, and floor structure to chassis to secure and maintain continuity between the floor and chassis, so as to resist wind overturning and sliding as imposed by design loads in 6.3 .1 of this Part. (Directions for anchorage shall accompany all mobile homes.) 
6.5.1 Tiedowns. All mobile homes shall have tiedowns with provisions for distributing the load of these tiedowns and provision for the attachment to ground anchors so as to resist wind overturning and sliding as imposed by the respective design loads of this Part.

6.5.1.1 Each tiedown shall be designed to resist an allowable working load equal to or exceeding 3,150 pounds and shall be capable of withstanding a 50 percent overload without failure.

6.5.1.2 Unless the tiedown system is designed by a Registered Professional Engineer or Architect, tiedowns shall be placed as follows:

(a) Hurricane Zones. Not more than 12 feet on centers beginning from the front wall (first stud and/or first cross member). Not more than 6 feet open-end spacing shall be provided at the rear wall of the mobile home unless additional tiedowns are installed.

(b) Nonhurricane Zones. Not more than 24 feet on centers beginning from the front wall (first stud and/or first cross member). Not more than 6 feet open-end spacing shall be provided at the rear wall of the mobile home unless additional tiedowns are installed.

6.5.1.3 Provision for diagonal ties between ground anchors and the mobile home shall be made in conjunction with each vertical tiedown.

6.5.1.4 Tiedowns exposed to weathering shall be resistant to weathering deterioration at least equivalent to that provided by a coating of zinc on steel of not less than 0.30 ounces per square foot of surface coated.

Note: Type 1, Class B, Grade 1, steel strapping $11 / 4$ inches wide and 0.035 inch thick, conforming with Federal Specification QQ-S-781-F, is judged to conform with this Section.

6.5.1.5 The manufacturer shall provide printed instructions with each mobile home specifying the location and required capacity of stabilizing devices (tiedowns, piers, blocking, etc.) on which the design is based.

NJ (ANSI A119.1, 1974)

MOBILE HOME ADMINISTRATION

Bulletin $5-73$

SUbject: HURRICANE ZONE CONSTRUCTION AND FOUNDATION

The State of New Jersey is in the hurricane weather zone. Therefore, all mobile homes must conform to the hurricane zone standards of ANSI Al19.1, 1972.

Mobile home manufacturers must supply New Jersey dealers with a descriptive booklet and/or drawings showing the hurricane tiedown structures and foundations.

The authorized testing facilities should review and approve the same. The inspectors should inspect in the manufacturers" plans and issue the New Jersey mobile home registration seals to those units only.

MOBILE HOMES ADMINISTRATION

Bulletin 8-74

Subject: TIEDOWNS FOR DOUBLE-WIDE MOBILE HOMES

ANSI Al19.1, 1974, Part B, Section 6.5.1: "All mobile homes shall have tiedowns . . ." needs clarification.

Under this Standard, the States of Florida, Virginia, and Texas already implemented their clarification of this Section. All single wides for hurricane zone usage should have overthe-roof vertical and frame diagonal ties. All double-wides in the hurricane zone will not require over-the-roof vertical ties. 
The State of New Jersey will adopt the above clarification as part of our Standards on tiedowns. The diagonal frame ties are the minimum requirement for all double-wide mobile homes manufactured and/or sold in this state. Any additions or canopies from single wides must be secured by both vertical and diagonal ties. Since the entire State of New Jersey is under the hurricane zone, the above clarification will apply throughout the State. The remaining requirements of Section 6.5, Part B, ANSI A119.1, 1974, will be enforced as stated.

Ref: State of New Jersey, Department of Community Affairs, Division of Housing and Urban Renewal; Mobile Homes Administration, Bulletin Letter, October 16, 1974, amends, "The Uniform Standards Code for Mobile Homes."

\section{OH (ANSI A119.1, 1974)}

BB-77-11.03. Vertical Tiedowns. Vertical tiedowns shall be provided with over-the-top straps at each tiedown location unless the unit has been designed to maintain the structural continuity of Paragraph 6.5, Part B of ANSI A119.1, and is provided with tiedown hardware as required by section $B B-77-05$ (B) 4. OBC, in which case additional over-the-top straps are not necessary. Double-wide units are not required to have over the roof tiedowns unless specified by the manufacturer.

BB-77-11.05. Diagonal Ties. Diagonal cross-bracing ties between ground anchors and unit frame anchors shall be provided in conjunction with each vertical tiedown. Double-wide units are required to be diagonally tied at each support in the same manner as single units and diagonally tied between the center supports.

BB-77-11.06. Tie Straps. Vertical and diagonal tie straps shall conform to the stress requirements of this chapter. When steel bands or cables are used for over-the-top tiedowns, they shall be placed over stud and rafter locations for structural support and shall not rest on corners without approved corner buffer brackets or similar devices to protect roof edge, corners, and ties from damage. Bands shall be protected with D-rings or other approved device at connection ends to prevent distortion of band and provided with approved tensioning devices. Cables shall be protected by thimbles at connection ends and provided with approved tensioning devices.

All tensioning devices shall be stress and weather-resistant rated in accordance with the requirements of this chapter and no hook-end connection anchors or turn-buckles are permitted for anchoring.

Tensioning shall not proceed until straps or cables are properly aligned to prevent twist, shearing, or cutting of ties or unit. Each tie shall be tensioned in accordance with manufacturers' requirements tut caution should be used to prevent over tensioning of ties which may damage unit or reduce their capability to hold in heavy or gusting wind conditions. Ref: Ohio Building Code, Chapter BB-77, Industrial Units (Mobile Homes and Recreational Vehicles) Section BB 77.03, 05, 06, Mobile Home Standards and Modifications.

\subsection{WALLS}

ANSI A119.1, $1974 \& 1975$

$6.6 \mathrm{Walls}$. The walls shall be of sufficient strength to withstand the load requirements as defined in $6.3 .1,6.3 .2$, and 6.4 of this Part, without exceeding the deflections as specified in 6.10. The connections between the bearing walls, floor, and roof framework members shall be fabricated in such a manner as to provide support for the material used to enclose the mobile home and to provide for transfer of all lateral and vertical loads to the floor and chassis. 
SECTION $6.6=-$ WALLS

Note: If $15 / 8$ stud or $25 / 8$ studs are used, they must be designed in accordance with Section 6, USAS-A119.1 in accordance with an accepted engineering practice standard. Calculations showing the structural analysis by a registered architect or registered engineer or tests by an independent testing laboratory may be required.

The following are excerpts from the Residential Bullding Code for non-designed walls.

Exterior Walls.

Studs shall not be less than $2 \times 4^{\prime} \mathrm{s}$, wide face perpendicular to wall, spaced not more than 16 inches $0 . c$. or 24 inches $0 . c$. for $3 / 8^{\prime \prime}$ laminated wood finish. [Section 21(2)]

A11 window and door openings shall have studs doubled on jambs. [Section 21(3)]

Except when plywood, dlagonal sheathing, or approved structural insulation board is used, all external corners shall have diagonal 1 × 4 inch braces let into the top and bottom plates and the face of the study as approximately 45 degrees and wherever possible shall extend from sill to plates. Braces shall be securely nailed to each stud and to sill and plate. Where openings occur near the corner, 1 x 4 inch knee braces shall be installed above and below the openings at approximately 45 degrees extending across not less than 3 stud spaces and shall be let into the face of the studs. [Section 21(10)] Ref: State of North Carolina, Regulations for Mobile Homes, 1972 Edition.

\subsection{INTERIOR WALLS}

ANS I A119.1, 1975

6.7 Interfor Wa11s. Interior walls shall be constructed with structural capacity adequate for the Intended purpose and shall be capable of resisting a horlzontal load of not less than five pounds per square foot.

ANS I A119.1, 1974

6.7 Interior Partition. Whenever an interior partition is designed to serve as a secondary structural member, it shall be constructed with adequate strength for the purpose intended.

NM (ANSI A119.1, 1973)

103-ANSI A119.1 Modification

All interior walls must be firmly attached both top and bottom and particularly at the point of attachment of doors or at the ends before openings. Where the arrangement of rafters or trussing or floor jolnts is such that the interior wall cannot be firmly attached, adequate blocking must be provided.

Ref: State of New Mexico, Rules, Regulations, and Standards of the Construction Industries Commission for the Mobile Home Board, August 1, 1974.

NC (ANSI A119.1, 1974)

SECTION 6.7--INTERIOR PARTITIONS

(1) Studs shall be not less than $2 \times 4 \mathrm{~s}$, wide face perpendicular to wall, spaced not more than 16 inches $0 . c$. or 24 inches $0 . c$. for 3/8" laminated wood finish. [Section 22(1)]

Note: Nonbearing partitions may be $2 \times 2$ 's, with maximum spacing 24 inches $0 . c$. Ref: State of North Carolina, Regulations for Mobile Homes, 1972 Edition. 
ANSI A119.1, 1974 \& 1975

6.8 Firestopping. Firestopping shall be provided in multistory mobile homes to cut off all concealed draft openings in all stud walls and partitions, including furred spaces, so placed that the maximum vertical dimension of any concealed space is not over eight feet.

NC (ANSI A119.1, 1974)

Section 6.8 - Firestopping - Delete this section because if mobile homes are to be multistory construction, they would have to meet the State Building Code.

Ref: North Carolina State Building Code Council adoption of "State of North Carolina Standards for Mobile Homes" with amendments; [ANSI A119.1-74 (NFPA B-73) adopted March 12, 1974].

\subsection{FLOORS}

ANSI A119.1, 1975

6.9 Floors.

(a) Floor assemblies shall be designed in accordance with accepted engineering practice standards to support a minimum uniform live load of $401 \mathrm{~b} / \mathrm{ft}^{2}$ plus the dead load of the materials. In addition (but not simultaneously), floors shall be able to support a 200pound concentrated load on a two-inch diameter disc at the most critical location with a maximum deflection not to exceed one-eighth inch relative to floor framing. Perimeter joists of more than six inches depth shall be stabilized against overturning from superimposed loads as follows: at ends by solid blocking not less than two-inch thickness by full depth of joist, or by connecting to a continuous header not less than two-inch thickness and not less than the depth of the joist with connecting device; at eight-feet maximum intermediate spacing by solid blocking or by wood cross-bridging of not less than one inch by three inches, metal cross-bridging of equal strength, or by other approved methods.

(b) Wood floors or subfloors in kitchens, bathrooms (including toilet compartments), laundry rooms, water heater compartments, and any other areas subject to excessive moisture shall be moisture resistant or shall be made moisture resistant by sealing or by an overlay of nonabsorbent material applied with water-resistant adhesive.

(c) Carpeting shall not be used under a heat-producing appliance unless the appliance is listed for such use.

ANSI A119.1, 1974

6.9 Floors. Floor assemblies shall be designed in accordance with accepted engineering practice to support a uniform live load of $40 \mathrm{lb} / \mathrm{ft}^{2}$, plus the dead load of the materials. In addition (but not simultaneously), floors shall be able to support a 200-pound concentrated load on a 2-inch diameter disc at the most critical location with a maximum deflection not to exceed $1 / 8$ inch relative to floor framing.

NC (ANSI A119.1, 1974)

Wood Floors, Ceilings and Roofs

Joists of a grade with an $f$ value of 1,200 and $E$ value of $1,760,000$ shall not exceed the span limitations set forth in Table A. Floor joists of other grades or of other sizes may be used in accordance with "Maximum Spans for Joists and Rafters in Residential Construction," as published by the National Forest Products Association, February 1961; or may be 
designed in accordance with accepted engineering practice. [Section 20(15) of Residential Code)

TABLE A--MAXIMUM SPANS FOR JOIST AND RAFTERS

(Based on A Grade Providing an $E$ of $1,760,000$ and an $f$ of 1200)

\begin{tabular}{|c|c|c|c|c|c|}
\hline & & \multicolumn{2}{|c|}{ FLOOR JOISTS } & \multicolumn{2}{|c|}{$\begin{aligned} & \text { LOW } \text { SLOPE } \\
& \text { ROOF } \text { JOISTS } \\
&\end{aligned}$} \\
\hline $\begin{array}{l}\text { Nominal } \\
\text { Size C t }\end{array}$ & $\begin{array}{l}\text { Spacing } \\
\text { to } \mathrm{C}\end{array}$ & \multicolumn{2}{|c|}{ 40\# L.L. } & \multicolumn{2}{|c|}{ 20非 L.L. } \\
\hline $2 \times 4$ & $\begin{array}{l}12 \\
16 \\
24\end{array}$ & & & \multicolumn{2}{|c|}{$\begin{array}{l}7^{\prime} 7 " \\
6 ' 11 " \\
6^{\prime} 1 " 1\end{array}$} \\
\hline $2 \times 6$ & $\begin{array}{l}12 \\
16 \\
24\end{array}$ & $\begin{array}{r}11 \\
10 \\
8\end{array}$ & $\begin{array}{l}5 \\
1 \\
3\end{array}$ & $\begin{array}{r}14 \\
12 \\
9\end{array}$ & $\begin{array}{r}0 \\
2 \\
10\end{array}$ \\
\hline $2 \times 8$ & $\begin{array}{l}12 \\
16 \\
24\end{array}$ & $\begin{array}{l}14 \\
13 \\
11\end{array}$ & $\begin{array}{l}9 \\
6 \\
0\end{array}$ & $\begin{array}{l}18 \\
16 \\
13\end{array}$ & $\begin{array}{l}8 \\
2 \\
2\end{array}$ \\
\hline $2 \times 10$ & $\begin{array}{l}12 \\
16 \\
24\end{array}$ & $\begin{array}{l}18 \\
16 \\
14\end{array}$ & $\begin{array}{l}3 \\
9 \\
0\end{array}$ & $\begin{array}{l}23 \\
20 \\
16\end{array}$ & $\begin{array}{l}7 \\
5 \\
8\end{array}$ \\
\hline $2 \times 12$ & $\begin{array}{l}12 \\
16 \\
24\end{array}$ & $\begin{array}{l}21 \\
19 \\
16\end{array}$ & $\begin{array}{r}9 \\
11 \\
11\end{array}$ & $\begin{array}{l}28 \\
24 \\
20\end{array}$ & $\begin{array}{l}7 \\
9 \\
2\end{array}$ \\
\hline
\end{tabular}

ALLOWABLE SPANS FOR PLYWOOD FLOOR AND ROOF

SHEATHING CONTINUOUS OVER TWO OR MORE SPANS

AND FACE GRAIN PERPENDICULAR TO SUPPORTS

\begin{tabular}{|c|c|c|c|c|c|c|}
\hline & & \multicolumn{3}{|c|}{ Roof } & \multicolumn{2}{|r|}{ Floor } \\
\hline $\begin{array}{l}\text { Plywood } \\
\text { Thickness } \\
\text { (Inches) }\end{array}$ & $\begin{array}{l}\text { Panel Identi } \overline{2} \\
\text { fication Index }\end{array}$ & & $\begin{array}{l}\text { num } \\
\text { an } \\
\text { hes) }\end{array}$ & $\begin{array}{l}\text { Loads } \\
\text { Tota1 } \\
\text { Load } \\
\end{array}$ & $\begin{array}{l}\text { Lsf) } \\
\text { Load } \\
\text { Live }\end{array}$ & $\begin{array}{c}\text { Maximum } \\
\text { Span } \\
\text { (Inches) } \\
\end{array}$ \\
\hline $\begin{array}{l}5 / 16 \\
5 / 16,3 / 8 \\
5 / 16,3 / 8 \\
3 / 8,1 / 2 \\
5 / 8 \\
1 / 2,5 / 8 \\
3 / 4 \\
5 / 8,3 / 4,7 / 8 \\
3 / 4,7 / 8 \\
\end{array}$ & $\begin{array}{l}12 / 0 \\
16 / 0 \\
20 / 0 \\
24 / 0 \\
30 / 12 \\
32 / 16 \\
36 / 16 \\
42 / 20 \\
48 / 24\end{array}$ & $\begin{array}{c}\text { Edges } \\
\text { Blocked } \\
12 \\
16 \\
20_{5} \\
24^{5} \\
30 \\
32 \\
36 \\
42 \\
48 \\
\end{array}$ & $\begin{array}{c}\text { Edges } \\
\text { Unblocked } \\
12 \\
75 \\
20 \\
24 \\
26 \\
28 \\
30 \\
32 \\
36 \\
\end{array}$ & $\begin{array}{r}130 \\
75 \\
55 \\
60 \\
55_{3}^{3} \\
50_{3}^{3} \\
50_{3}^{3} \\
45_{3}^{3} \\
40^{3}\end{array}$ & $\begin{array}{r}100 \\
55 \\
45 \\
45 \\
40 \\
40_{3} \\
35^{3} \\
35^{3} \\
40 \\
\end{array}$ & $\begin{array}{r}0 \\
0 \\
0 \\
0 \\
126 \\
167 \\
167 \\
20 \\
24 \\
\end{array}$ \\
\hline
\end{tabular}

1 These values apply for Structural I and II, Standard Sheathing and C-C grades only. Spans shall be limited to values shown because of possible effect of concentrated loads.

2 Identification Index appears on all panels in the construction grades listed in footnote (1).

3 For roof live load of 40 psf or total load of 55 psf, decrease spans by 13 percent or use panel with next greater identification index.

4 Plywood edges shall have approved tongue and groove joinst or shall be supported with blocking, unless one-fourth (1/4) inch minimum thickness underlayment is installed, or finish floor is 25/32" wood strip. Allowable uniform load based on deflection of $1 / 360$ of span is 100 psf.

$532 / 16$ Structural I, when continuous over one support, may be laid with face grain parallel to supports provided all panel edges are blocked or other approved type edge support is provided, the spacing of the supports does not exceed twenty-four inches (24") on center, 
and the live load does not exceed 30 pounds per square foot. For other grades, a thickness of five-eighths inch ( $\left.5 / 8^{\prime \prime}\right)$ is required.

6 May be $16^{\prime \prime}$ if $25 / 32^{\prime \prime}$ wood strip flooring is installed at right angles to joists.

7 May be $24^{\prime \prime}$ if $25 / 32^{\prime \prime}$ wood strip flooring is installed at right angles to joists.

* The first numeral denotes spans for roofs and second numeral for floors.

Note: All plywood when used structurally (including among others, used for siding, roof and wall sheathing, subflooring, diaphragms, and built-up members) shall conform to the performance standards for its type in U.S. Products Standard PS 1-66 for Softwood P1ywood, Construction and Industrial. Each panel or member shall be identified for grade and glue type by the trade marks of an approved testing and grading agency. In addition, all Plywood when permanently exposed in outdoor applications shall be of Exterior type.

ALLOWABLE SPANS FOR PLYWOOD COMBINATION SUBFLOOR--UNDERLAYMENT ${ }^{1}$

Plywood Continuous over Two or More Spans and

Face Grain Perpendicular to Supports Species Groups Maximum Spacing of Joists (Inches)

\begin{tabular}{llll} 
& $16^{\prime \prime}$ & $20^{\prime \prime}$ & $24^{\prime \prime}$ \\
\cline { 2 - 4 } 1 & $1 / 2^{\prime \prime}$ & $5 / 8^{\prime \prime}$ & $3 / 4^{\prime \prime}$ \\
2,3 & $5 / 8^{\prime \prime}$ & $3 / 4^{\prime \prime}$ & $7 / 8^{\prime \prime}$ \\
4 & $3 / 4^{\prime \prime}$ & $7 / 8^{\prime \prime}$ & $1^{\prime \prime}$ \\
\hline
\end{tabular}

1 Applicable to Underlayment grade, C-C (Plugged) and all grades of sanded Exterior type plywood. Spans limited to values shown because of possible effect of concentrated loads. Allowable uniform load based on deflection of $1 / 360$ of span is 100 psf. Plywood edges shall be supported with blocking, unless one-fourth (1/4) inch minimum thickness underlayment is installed, or finished floor is $25 / 32^{\prime \prime}$ wood strip. If wood strips are perpendicular to supports, thicknesses shown for 16 and $20^{\prime \prime}$ spans may be used on $24^{\prime \prime}$ spans.

Ref: State of North Carolina, Regulations for Mobile Homes, 1972 Edition.

\subsubsection{Drilling or Notching of Wood Joist Structural Members}

ANSI A119.1, $1974 \& 1975$

6.9.1 Drilling or Notching of Wood Joist Structural Members. Except where substantiated by engineering design, notches on the ends of joists shall not exceed one-fourth the joist depth. Holes bored in joists shall not be within 2 inches of the top or bottom of the joist, and the diameter of any such hole shall not exceed one-third the depth of the joist. Notches in the top or bottom of the joists shall not exceed one-sixth the depth and shall not be located in the middle third of the span.

NC (ANS I A119.1, 1974)

Notching of Joist

(a) The top or bottom edges of joists may be notched not to exceed $1 / 6$ of the joist depth but notching the top or bottom edge of joists will not be permitted in the middle third of any joist span. [Section 20(16)(a)]

(b) If cutting of floor joist more than $1 / 6$ of its depth is found necessary, a header the full depth of the joist shal1 be cut in to support the end of the joist. [Section 20(16)(b)]

(c) Where location of pipes necessitates passing through the joists, holes shall be drilled to receive the pipes. The diameter of the holes shall not be more than $1 / 2$ inch greater than the outside diameter of the pipe and in no case greater than $21 / 2$ inches. The edge of the holes shall not be located nearer than two inches from the top or bottom edge of the joists. [Section 20(16)(c)]

Ref: State of North Carolina, Regulations for Mobile Homes, 1972 Edition. 


\section{7,3 Interior Walls, Partitions, and Ceilings}

ANS I A119.1, 1975

7.3 Intertor Walls, Partitions, and Ceilings. The interior finlsh of habitable rooms and hallways (excluding molding, doors, trim, cablnets, and splash panels), enclosures for furnaces and water heaters (Including doors) shall be of materlals whose flame spread classlfication shall not exceed 200 when tested by the Standard Method of Test for Surface Burning Characteristics of Building Materlals (ANSI A2.5-1970; UL723-1971; NFPA no. 2251972). A door or doors serving a closet with an opening exceeding 21 square feet shall comply with this requirement.

ANSI A119.1, 1974

7.3 Interior Walls, Partitions, and Ceilings. The interior finish of habitable rooms and hallways excluding molding, doors, trim, cabinets, and splash panels, shall be of materials whose flame spread classification shall not exceed 200 when tested by the Standard Method of Test for Surface Burning Character1stics of Building Materials (ANSI A2.5-1970; ASTM E84-70; UL 723-1971; NFPA No. 255-1972).

\section{CA (STATE CODE)}

4072. Inter1or Walls, Partitions, and Cellings. The interior finish of habitable rooms and hallways, excluding molding, doors, trim, cabinets, and splash panels, shall be of materials whose flame spread classification shall not exceed 200 when tested by the Standard Method of test for Surface Burning Characteristics of Bullding Materials (ANSI A2.5-1970; ASTM E84-70; UL 723-1971; NFPA No. 255-1972). Closet door(s) exceeding 21 square feet shall conform to this section.

Ref: California Administrative Register 73, No. 36-B, Title 25, Housing and Community Development, Division 13, Part 2, Chapter 1, September 8, 1973.

MI (NFPA 501B, 1973)

7.3. Interior walls, partitions and ceilings. The interior finish of habitable rooms and hallways (excluding molding, doors, trim, cabinets, and splash panels), shall be of materials whose flame spread classification shall not exceed 200 when tested by the Standard Method of Test for Surface Burning Characteristics of Building Materials (ANSI A2.5-1970; ASTM E84-70; UL 723-1971; NFPA No. 255-1972). A door or doors serving a closet with an opening exceeding 21 square feet shall comply with this requirement. The interior finish of enclosures for furnaces and water heaters (Including doors) shall be of materlals whose flame spread rating shall not exceed 25 .

Ref: Department of Labor, Construction Code Commission, Mobile Home Code, Emergency Rules, Part 6, Mobile Home Code $R 408.30611$.

NV (NFPA 501B, 1973)

215. NONCOMBUSTIBLE MATERIALS REQUIRED. Every mobile home manufactured after the effective date of these regulations, sold or offered for sale in this state, shall be equipped with noncombustible material, the equivalent of $3 / 8$ inch plasterboard, in the following locations:

1. Gas water heater and gas and oil heater enclosures; and

2. Behind gas stoves and gas broilers and gas stove and broiler combinations. This does not include behind or beneath surface units or free standing stoves.

225. FIRE PARTITION REQUIRED. Every mobile home manufactured after the effective date of these regulations, sold or offered for sale in this State, fire stopping solid center span in the ceiling therof, which system and partition is approved by the division and the commission.

Ref: Nevada State Fire Marshal Division, Mobile Home and Manufactured Building Section, Regulations for Mobile Homes and Travel Trailers. 


\subsection{INTERIOR SURFACES, TRIM AND DECORATIVE MATERIALS}

(a) Interior surfaces of walls and ceilings, interior trim and decorative materials furnished and installed by the manufacturer of the mobile home excluding paint, wallpaper and materials less than 1/64 inch thick, shall have a flame-spread rating not exceeding 75 ; and shall be of materials that, in burning, will not give off excessive amounts of smoke or objectionable gas. The effective date of this subdivision shall be July 15, 1975.

(b) Skylights and windows glazed with plastic materials which give off smoke or gas denser or more toxic than given off by untreated wood or paper under comparable exposure to heat or flame, or which burn faster than two and one-half inches per minute as determined by tests conducted in conformity with generally accepted standards, shall not be permitted.

Ref: Division of Housing and Community Renewal, Generally Accepted Standards applicable to State Code for Construction and Installation of Mobile Homes, Part 1093, Fire Safety Requirements; March 13, 1974.

NC (ANSI A119.1, 1974)

Section 7.3 - Interior Walls and Partitions - Add the following sentence which was deleted from the 1969 edition: "ALL WALL AND PARTITION SURFACES SHALL BE CAPABLE OF RESISTING HORIZONTAL LOAD OF NOT LESS THAN 5 POUNDS PER SQUARE FOOT." The 1973 edition provides for no horizontal load resistance.

Ref: North Carolina State Building Code Council adoption of "State of North Carolina Standards for Nobile Homes" with amendments; [ANSI Al19.1-74 (NFPA B-73) adopted March 12, 1974]。

NC (ANSI A119.1, 1974)

Note: All plywood and other combustible surfaces used as finish for walls and ceilings shall be identified by the label of Underwriter's Laboratories or other testing agency approved by the Building Code Council with follow-up inspection service as having flame spread of 200 or less.

Ref: State of North Carolina Regulations for Mobile Homes, 1972 Edition.

NOTE: Also refer to data sheet on Section 5.7, "Acceptability of Material."

\subsection{HEAT LOSS}

ANSI A119.1, $1974 \& 1975$

7.5 Heat Loss. The total calculated heat loss of the living unit at the outdoor design temperature as certified in 7.5 .1 of this Part shall not exceed $40 \mathrm{Btu} / \mathrm{hr} / \mathrm{ft}^{2}$ of the total floor area or $275 \mathrm{Btu} / \mathrm{hr}$ lineal $\mathrm{ft}$. of the perimeter of the space to be heated to $70^{\circ} \mathrm{F}$, whichever is greater. The minimum total resistance value $(R)$, excluding framing, of the wall (less windows and doors), ceiling, and floor shall not be less than:

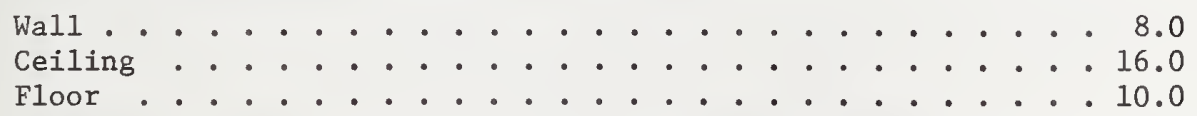

7.5.1 The mobile home manufacturer shall permanently affix the following "Certificate" to an interior surface of the home that is readily visible to the homeowner. The Certificate shall specify the following:

(a) The lowest outdoor design temperature (15 MPH wind) at which the mobile home heat loss complies with Paragraph 7.5. 
(b) The lowest outdoor tempertiture (15 MPH wind) at which the installed heating equipment will maintaln a $70^{\circ} \mathrm{F}$ temperature inside the home with or without storm sash.

\begin{tabular}{|c|}
\hline CERTIFICATE \\
\hline Home Mfgr.____ Plant I.ocation \\
\hline Hoine Model \\
\hline $\begin{array}{l}\text { The living area of this home is designed to maintain comfort heating } \\
\text { where the outdoor temperatures are not lower than -F when the home } \\
\text { is equipped with storm windows and not lower than }-F \text { when the } \\
\text { home is not equipped with storm windows. }\end{array}$ \\
\hline Heating Equipment Mfgr. \\
\hline Heating Equipment M Iodel \\
\hline $\begin{array}{l}\text { The above heating equipment has the eapacity to maintain an average } \\
70 \mathrm{~F} \text { temperature in this home at outdoor temperatures of } \mathrm{F} \text {. when } \\
\text { home is equipped with storm windows and } \\
\text { equipped with storm windows. }\end{array}$ \\
\hline $\begin{array}{l}\text { The above information has been caleulated assuming a maximum wind } \\
\text { velocity of } 15 \text {. } 1 \text { PH as standard atmospherie pressure. }\end{array}$ \\
\hline
\end{tabular}

7.5.2 "R" values and "U" factors shall be calculated as outlined in the latest edition of the ASHRAE Handbook of Fundamentals. *

7.5.3 Framing Heat Loss. In the absence of specific data, for the purpose of heat loss calculations, the following framing areas shall be assumed:

Wal1 . . . . . . . . . . . 20\% of net wall area (less windows)

Ceiling . . . . . . . . . . . . 5\% of total ceiling area

Floor . . . . . . . . . . . 10\% of net $\mathrm{floor}$ area (less duct area)

7.5.4 Infiltration Heat Loss. The following shall be used to estimate infiltration heat loss, or infiltration heat loss may be calculated using the method in the ASHRAE Handbook of Fundamentals*:

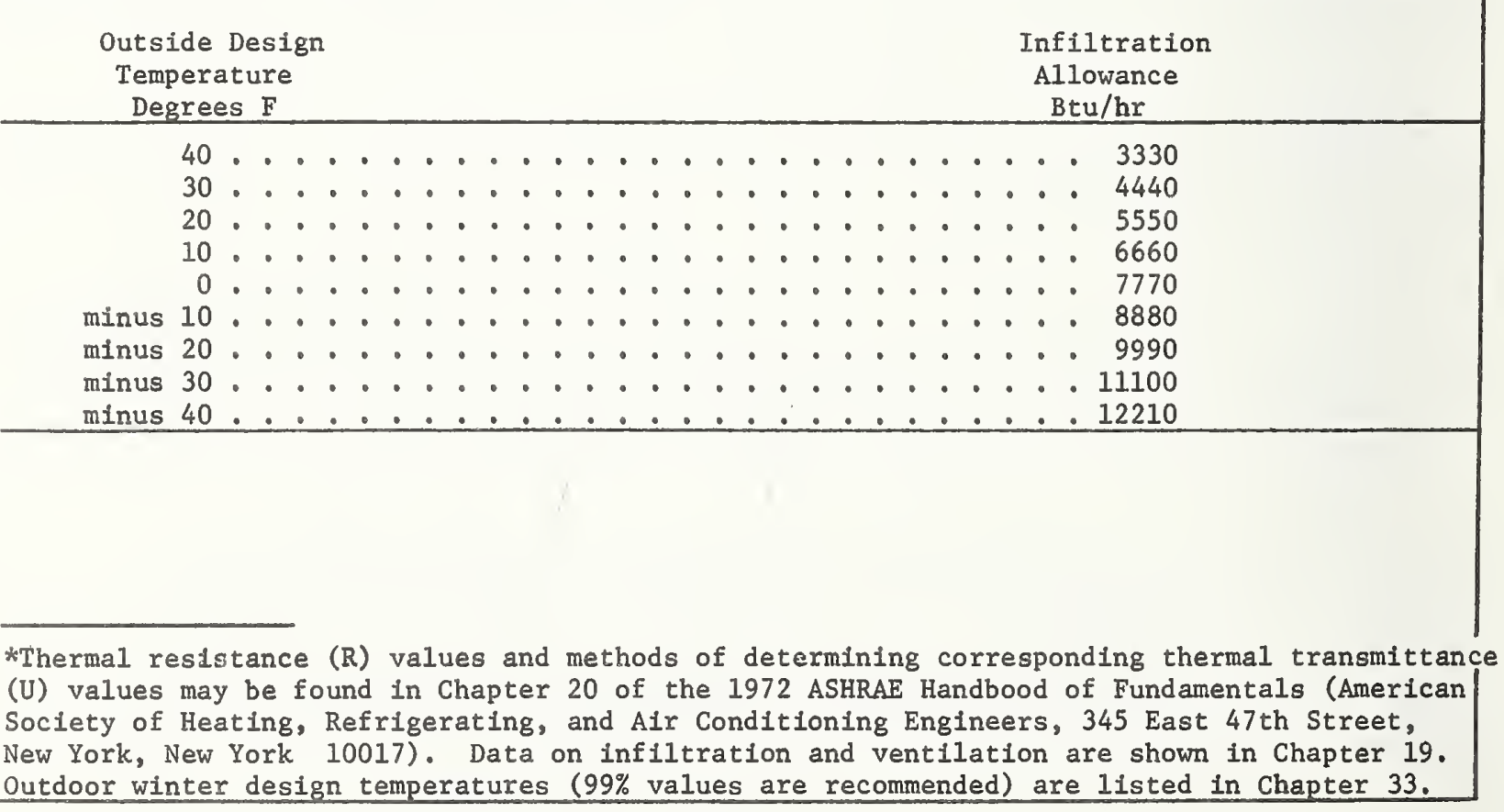


(4) Subparagraph $7.5 . \mathrm{C}$ of Part $\mathrm{B}$ is changed to read:

"c. The minimum total resistance values (R) of the wall (less windows and doors), ceiling and floor shall not be less than the following:

Wa11 - 10

Ceiling - 16

Floor - 12

The total ' $R$ ' value is obtained by adding the insulation ' $R$ ' value together with the ' $R$ ' value of mobile home construction. Typical mobile home construction ' $R$ ' values excluding framing, have been calculated to be: Sidewall ' $R$ ' $=2.0$; Floor and ceiling ' $R$ ' $=3.0$. These typical ' $R$ ' values are to be calculated using all component materials and spaces as outlined in the 1972 Edition of the ASHRAE Handbook of Fundamentsls."

(5) Subparagraph 7.5.1.a of Part B is changed to read:

"a. The lowest outdoor design temperature (15 MPH wind) at which the mobile home heat loss complies with paragraph 7.5 of this Part shall be:

$$
\begin{aligned}
& \text { Zone } 1--20^{\circ} \mathrm{F} \text { (15 MPH wind) } \\
& \text { Zone } 2--30^{\circ} \mathrm{F} \text { (15 MPH wind) } \\
& \text { Zone } 3--60^{\circ} \mathrm{F} \text { (15 MPH wind) }
\end{aligned}
$$

Zore 1 includes:

The Aleutian Islands.

Pribilof Islands, St. Mathew Islands and other adjacent islands.

Alaska Peninsula south of $58^{\circ}$ north latitude.

Kodiak Island Group

Southeast Alaska mainland and Alexander Archipelago north to Icy Cape (60 north latitude)

Zone 2 includes:

That area of the Alaska mainland draining into Prince William Sound between Whittier and Icy Cape, but not extending above Thompson Pass on the Richardson Highway or Miles Glacier on the Copper River drainage; and all islands in Prince William Sound.

The Alaska Peninsula north of $58^{\circ}$ north latitude and adjacent islands.

That part of the mainland draining into Bristol Bay between Cape Newenham and Knichak Bay and the adjacent islands between these points.

That part of the mainland draining into Cook Inlet south of $61^{\circ} 50^{\prime}$ north latitude and west of west longitude $148^{\circ}$.

The Kenai Peninsula and adjacent islands.

Zone 3 includes:

The remainder of mainland Alaska and adjacent islands including St. Lawrence Island."

(6) Subparagraph 7.5 .4 of Part B is amended by adding:

$$
\begin{aligned}
& "-50^{\circ}-13,300 \\
& -60^{\circ}-14,400^{\prime \prime}
\end{aligned}
$$

b. The manufacturer's Certificate posted in the mobile home (paragraph 7.5 .1 of this Part) shall state that the mobile home has been designed for the structural requirements set out in paragraph 6.3 of this Part and this paragraph."

Ref: Chapter 36, Standard for Mobile Homes, Article 2, Construction Standards, April 1973. 
4073. Certificate. The mobile home manufacturer shall permanently affix the following "Certificate" to an interfor surface of the home that is readily visible to the homeowner. The certificate shall specify the following:

(a) The lowest outdoor design temperature (15 MPH wind) at which the mobile home heat loss complies with Section 4079 or 7.5 , NFPA 501B, Part B.

(b) The lowest outdoor temperature (15 MPH wind) at which the installed heating equipment will maintain a $70^{\circ} \mathrm{F}$ temperature inside the home with or without storm sash.

(c) The loads for which the mobile home is designed for (see Sections 4058, 4059, and 4060).

NOTE: Fireplace stoves shall not be considered as heating facilities for compliance with Section 4079 of this chapter or 7.5, NFPA 501B, Part B.

\section{CERTIFICATE}

Home Mfgr.

Plant Location

Home Model

This home is insulated for locations where outdoor temperatures are not lower than F, when home is equipped with storm windows and not lower than _ F, when home is not equipped with storm windows.

Heating Equipment Mfgr.

Heating Equipment Mode1

The above heating equipment has the capacity to maintain an average $70^{\circ} \mathrm{F}$ temperature in this home at outdoor temperatures of $F$ when home 1 s equipped with storm windows and $F$ when home is not equipped with storm windows. The above information has been calculated assuming a maximum wind velocity of $15 \mathrm{MPH}$ at standard atmosphere pressure.

Roof Live Load . . . . . . . . . . . . . . . . . . . . . . . . . . . . . . . . . . . . Psf
Wind Load

4079. App11cation. (a) All habitable rooms shall be provided with heating facilities capable of maintaining a room temperature of $70^{\circ} \mathrm{F}$ at a point three feet above the floor w1th $15 \mathrm{~m} 1 \mathrm{les}$ per hour wind velocity at a designated outdoor design temperature. The department shall be furnished with written certification that the mobile home is designed to comply with this requirement.

(b) The mobile home manufacturer shall permanently affix a certificate (depending on type of heat) to an interfor surface of the home that is readily visible to the homeowner. The certificate shall specify the following:

(1) The lowest outdoor design temperature (15 MPH wind) at which the mobile home heat 10 s complies with this section.

(2) The lowest outdoor temperature (15 MPH wind) at which the 1nstalled furnace w111 maintain a $70^{\circ} \mathrm{F}$ inside the home with or without otorm ash.

(c) Heat Loss. The total calculated heat loss of the moblle home at the outdoor design temperature shall not exceed the following:

(1) For gas and oll-heated moblle homes, $50 \mathrm{Btu} / \mathrm{hr} \mathrm{ft}^{2}$ of the total floor area, or $333 \mathrm{Btu} / \mathrm{hr} 1$ ineal $\mathrm{ft}$. of the perimeter of the space to be heated to $70^{\circ} \mathrm{F}$, whichever $1 \mathrm{~s}$ the greater.

(2) For electrically-heated moblle homes, $40 \mathrm{Btu} / \mathrm{hr} \mathrm{ft}^{2}$ of the total floor area or 267 Btuh per 11neal foot of the perimeter of the space to be heated to $70^{\circ} \mathrm{F}$ or whichever $1 \mathrm{~s}$ greater.

(3) The minimum total resistance values ( $R$ ) of the wall (less windows and doors), celling and floor shall not be less than the following:

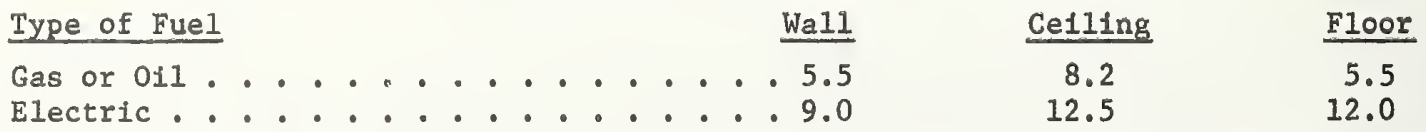

NOTE: The total " $R$ " value is obtained by adding the insulation " $R$ " value together w1th the " $R$ " value of mobile home construction. Typical mobile home construction " $R$ " values, 
excluding framing, have been calculated to be: Sidewalls $\mathrm{R}=2.0$; Floor and Ceiling $\mathrm{R}=3.0$. These typical " $R$ " values are to be calculated using all component materials and spaces as outlined in the 1967 Edition of the ASHRAE Handbook of Fundamentals.

(d) The provision of this section shall be applicable until December $31 ; 1973$.

NOTE: See Section 4052(c) for requirements after December 31, 1973.

Ref: California Administrative Register 73, No. 36B, Title 25, Housing and Community Development.

CO (ANSI A119.1, 1974)

(3) Delete Section 7.5, Part B, and substitute:

7.5 HEAT LOSS. "Every dwelling unit and guest room shall be provided with heating facilities capable of maintaining a room temperature of $70^{\circ} \mathrm{F}$ at a point $3^{\prime}$ above the floor in all habitable rooms. The total calculated heat loss of the living unit at the outdoor design temperature of $-20^{\circ} \mathrm{F}$ as certified in 7.5 .1 of this Part shall not exceed $40 \mathrm{BTU} / \mathrm{hr} / \mathrm{ft}{ }^{2}$ of the total floor area or $275 \mathrm{BTU} / \mathrm{hr}$ lineal $\mathrm{ft}$. of the perimeter of the space to be heated to $70^{\circ} \mathrm{F}$, whichever is greater. The minimum total resistance value (R) excluding framing, of the wall (less windows and doors) ceiling, and floor shall not be less than:



Ref: Notice of Adoption of Rules Regarding Construction Standards; Colorado Division of Housing; December 19, 1974.

$O H \quad($ ANS I A119.1, 1974)

5. Paragraph 7.5, Part B, Heat Loss - For the purpose of this chapter, total heat loss calculations shall be based on an 80 degree or more temperature differential, ( $1 . e .$, outdoor design temperature of at least minus 10 degrees $F$. to maintain an indoor temperature of 70 degrees $F$. with or without storm windows);

Ref: Ohio Building Code, Chapter BB-77, Industrialized Units (Mobile Homes and Recreational Vehicles) Section $B B-77-05$.

\subsubsection{FRAMING HEAT LOSS}

ANSI A119.1, $1974 \& 1975$

7.5.3 Framing Heat Loss. In the absence of specific data, for the purpose of heat loss calculations, the following framing areas shall be assumed:

$$
\begin{aligned}
& \text { Wall . . . . . . . . . } 20 \% \text { of net wall area (less windows) } \\
& \text { Ceiling . . . . . . . . } 5 \% \text { of total celling area } \\
& \text { Floor . . . . . . . } 10 \% \text { of net floor area (less duct area) }
\end{aligned}
$$

NC (ANSI A119.1, 1974)

SECTION 7.5.3--FRAMING HEAT LOSS

Note: If $15 / 8$ stud or $25 / 8$ studs are used, they must be designed in accordance with Section 6, USAS-Al19.1 in accordance with an accepted engineering practice standard. Calculations showing the structural analysis by a registered architect or registered engineer or tests by an independent testing laboratory may be required.

Ref: State of North Carolina Regulations for Mobile Homes, 1972 Edition. 
ANS I A119.1, 1974 \& 1975

8.2 Celing Height. Every habltable room shali have a minimum ceiling helght of not less than 7 feet, 0 inch in at least 50 percent of 1 tes required area with no portion of the required area less then 5 feet in helght. Hallways shall have a minimum celling haight of 6 feet, 6 inches.

NC (ANSI A119.1, 1974)

Section 8.2 - Ceiling Heights - Change the numeral " 5 " to the numeral " 6 ' 4 " to provide that $50 \%$ of each habitable room celling height would have to be $6^{\prime}-4^{\prime \prime}$ provided in the 1969 Edition in lieu of $5^{\prime}$.

Ref: North Carolina State Building Code Council adoption of "State of North Carolina Standards for Mobile Homes" with amendments; [ANSI A119.1-74 (NFPA B-73) adopted March 12, 1974].

TX (ANSI A119.1, 1974)

Documented Information not received in time for including in this report. The following 1nformation was given verbally:

"The Performane Certifieation Board for Mob1le Homes granted a request for a vartance of code to New-Way Mobile Homes basad on drawings oubmited to the Board and that the room which was granted as a variance of code bo a childran's room and that all other manufacturers which manufacture mobile homes having similar rooms will have to apply to the Board for a variance." (This applies to room heights for 14 foot wide moblle homes only.)

Ref:

\subsubsection{EXIT FACILITIES}

ANSI Al19.1, 1975

8.3.1 Exit Facilities

(a) Mobile homes shall have a minimum of two exterior doors located remote from each other and so arranged as to provide a means of unobstructed travel to the outside of the mobile home.

(b) Exterfor doors shall be constructed for exterior use and in no case provide less than a 28-inch-wide clear opening. Each swinging exterior door shall have a key-operated lock that has a deadlocking latch. A deadlock with a passage set installed below the deadlock may be used as an acceptable alternate for each exterior door. The locking mechanism of the lock shall be engaged or disengaged by the use of a lever, knob, button, handle, or other device from the side from which egress is to be made when the mobile home is occupied. Locks shall not require the use of a key for operation from the inside.

(c) Every room designed expressly for sleeping purposes, unless it has an exit door [See Par. 8.3.1(b)], shall have a least one outside window which can be opened from the inside without the use of tools to provide a clear opening of not less than 22 inches in least dimension and 5 square feet in area with the bottom of the opening not more than 4 feet above the floor. Where a screen or storm window is required to be removed from this window to permit emergency egress, it shall be readily removable without requiring the use of tools.

ANSI A119.1, 1974

\subsubsection{Exit Facilities}

(a) Mobile homes shall have a minimum of two exterior doors located remote from each other and so arranged as to provide a means of unobstructed travel to the outside of the mobile home. 
(b) Exterior doors shall be constructed for exterior use and in no case provide less than a 29-inch-wide clear opening. Each swinging exterior door shall have a key-operated lock that has a deadlocking latch. A deadlock with a passage set installed below the deadlock may be used an an acceptable alternate for each exterior door. The locking mechanism of the lock shall be engaged or disengaged by the use of a lever, knob, button, handle, or other device from the side from which egress is to be made when the mobile home is occupied. Locks shall not require the use of a key for operation from the inside.

(c) Every room designed expressly for sleeping purposes, unless it has an exit door [See Par. 8.3.1(b)], shall have at least one outside window which can be opened from the inside without the use of tools to provide a clear opening of not less than 22 inches in 1 east dimension and 5 square feet in area with the bottom of the opening not more than 4 feet above the floor.

MI (NFPA 501B, 1973)

MI Rule 616. Part B, section 8.3.1, paragraph (c) is amended to read as follows:

8.3.1(c). Every room designed expressly for sleeping purposes, unless is has an exit door (see Par. 8.3.1(b)), shall have at least one outside window which can be opened from the inside without the use of tools to provide a clear opening of not less than 22 inches in least dimension and 5 square feet in area with the bottom of the opening not more than 3 feet above the floor. Where a screen or storm window is required to be removed from this window to permit emergency egress, it shall be readily removable without requiring the use of tools.

Ref: Department of Labor, Construction Code Commission, Mobile Home Code, Emergency Rules, Part 6, dated May 29, 1974.

\subsection{Room and Hallway Sizes}

ANSI A119.1, $1974 \& 1975$

\subsection{Room and Hallway Sizes}

8.4.3 Each toilet compartment shall be a minimum of 30 inches in width and have at least 21 inches of clear space in front of each toilet.

8.4.4 Hallways shall have a minimum horizontal dimension of 28 inches.

MD (ANSI A119.1, 1974)

Minimum Floor Area for Mobile Homes

Section 8.4 of Part B - Construction of ANSI A119.1 specifies the minimum gross floor area required in mobile homes. However, gross floor area is not defined in the Standard. This has raised the question as to the proper method of measuring floor area. The BOCA Basic Building Code, which is the applicable code for other industrialized units, specifically excludes closet and storage spaces. Therefore, it is our determination that the same method of measurement shall apply in determining gross floor areas in mobile homes.

Ref: Maryland Codes Administration Information Bulletin No. 4, January 1973.

NJ (ANSI A119.1, 1974)

Mobile Homes Administration Bulletin 9-74

SUBJECT: CLARIFICATION OF MINIMUM WIDTHS FOR HALLWAY AND TOILET COMPARTMENT

ANSI A119.1-1974, Part B, Section 8.4.3: "Each toilet compartment shall be a minimum of 30 inches in width ..."; and Section 8.4.4: "Hallways sha11 have a minimum horizonta1 dimension of 28 inches," requires clarification. 
In the bathroom of some modeld, there is inadequate space adjacent to the tollet compartment allocated for use of optional items such as washer and dryer. After installation, the width of the tollet compartment has been reduced down to less than the Standard minimum requirement of 30 inches. The manufacturer should allow sufficient space, (suggested 60 fnehes width by 30 Inches depth for optional equipment); and also should inform the buyer of the exact size of the optlonal space designed for such future use. The third party for New Jersey should not approve any layouts, If the anticlpated optlonal equipemnt will reduce the open space below the mInImum required 30 Inches stated In the Standard.

Items such as wall lamps, fire alarm/detector devices, doorknobs, decorative fixtures, washer and dryer, etc., extending out into the hallway (within a height of seven feet from the floor) between two sidewalls must be considered narrowing down the hallway width. It. violates the basic principles of the Standard. Therefore, the minimum horizontal dimension of 28 inches for any hallway is implied with the net minimum 28 inches.

These clarifications will be applied to all mobile homes manufactured and/or sold in New Jersey after May 1, 1975.

Ref: State of New Jersey Department of Community Affairs, Division of Housing and Urban Renewal; Mobile Homes Administration, Bulletin letter, october 3, 1974.

\subsubsection{GLAZING IN HAZARDOUS LOCATIONS}

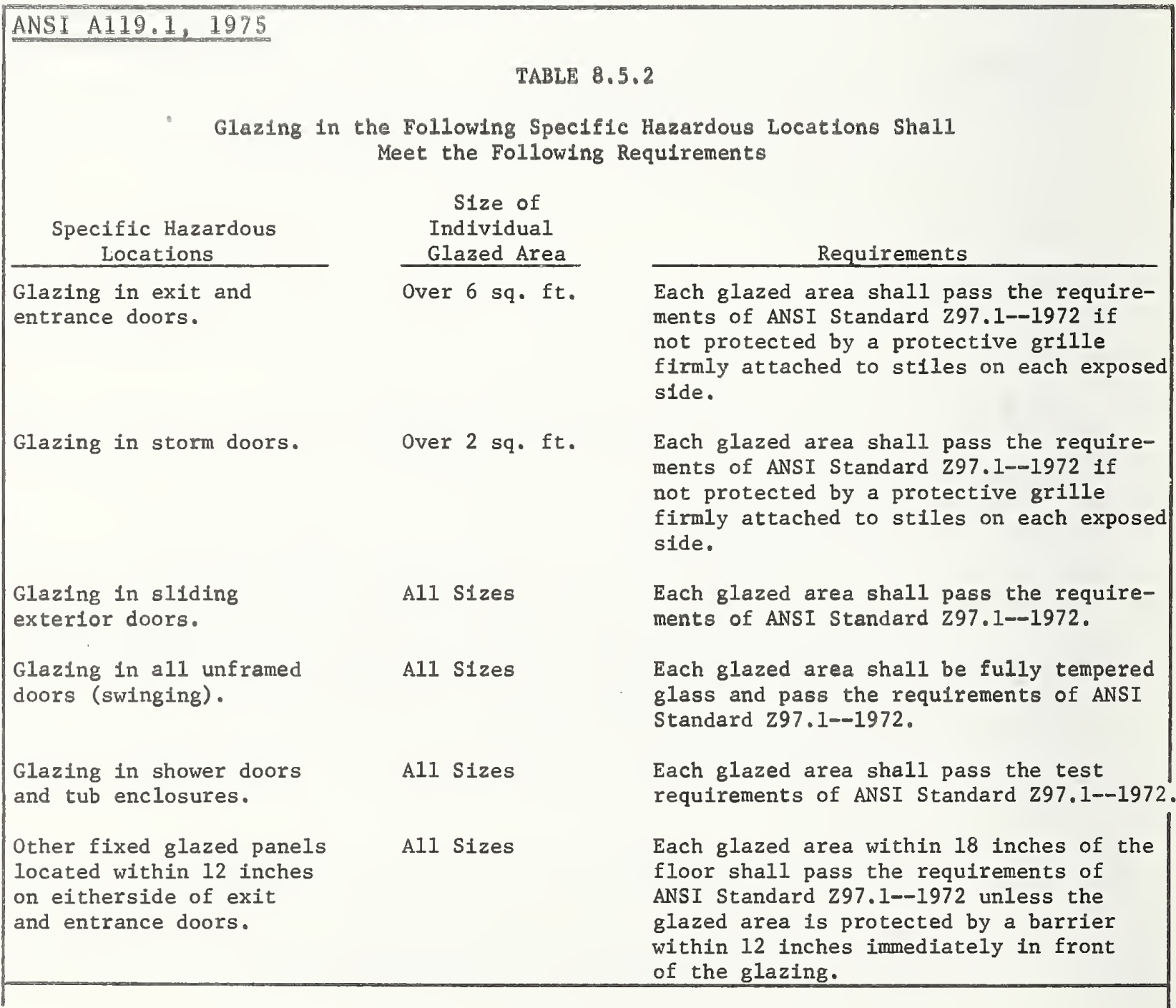


ANS I A119.1, 1974

\section{TABLE B-2}

Glazing in the Following Specific Hazardous Locations Shal1 Meet the Following Requirements

\section{Specific Hazardous Locations}

Glazing in exit and entrance doors and fixed glazed panels.

Glazing in storm doors.

Glazing in sliding doors (both fixed and sliding panels).

Glazing in al1 unframed doors (swinging).

Glazing in shower doors and tub enclosures.
Size of

Individual

Glazed Area

Over $6 \mathrm{sq}$. ft.

Over $2 \mathrm{sq}$. ft.
Requirement

Each glazed area shall pass the requirements of ANSI Standard Z97.1--1972 if not protected by a protective grille firmly attached to stiles on each side.

Each glazed area sha11 pass the requirements of ANSI Standard 297.1--1972 if not protected by a protective grille firmly attached to the stiles on each exposed side.

All Sizes

Each glazed area shall pass the requirements of ANSI Standard Z97.1--1972.

A11 Sizes

A11 Sizes
Each glazed area shall be fully tempered glass and pass the requirements of ANSI Standard 297.1--1972.

Each glazed area shall pass the test requirements of ANSI Standard Z97.1--1972.

\section{MI (NFPA 501B, 1973)}

R 408.30621. Glass and glazed openings.

Rules 621. Part B, section 8.5.1.1 is amended to read as follows:

8.5.1.1. Glazing in hazardous locations sha11 comply with Table B-2.

TABLE B-2

Glazing in the Following Specific Hazardous Locations Shall Meet the Following Requirements

Specific Hazardous Locations

Glazing in exit and entrance doors.

Fixed glazed panels.

Glazing in storm doors.

Glazing in sliding doors (both fixed and sliding panels).
Size of

Individual

Glazed Area

A11 Sizes

Fixed glazed panels over $300 \mathrm{sq}$. in.

Al1 Sizes

A11 Sizes
Requirement

Each glazed area shall pass the requirements of ANSI Standard 297.1--1972.

Each glazed area shall pass the requirements of ANSI Standard 297.1--1972.

Each glazed area shall pass the requirements of ANSI Standard 297.1--1972.

Each glazed area sha11 pass the requirements of ANSI Standard Z97.1--1972. 
Specific Hazardous Locations

Glazing in all unframed doors (swinging).
Size of

Individual

Glazed Area

Al1. Sizes
Requirement

Each glazed area shall be fully tempered glass and pass the requirements of ANSI Standard Z97.1--1972.

Each glazed area shall pass the test requirements of ANSI Standard Z97.1--1972.

Glazing in shower doors

Al1 Sizes and tub enclosures.

Ref: Department of Labor, Construction Code Commission, Mobile Home Code, Emergency Rules, Part 6, dated May 29, 1974.

\subsection{Plans for Physically Handicapped}

ANSI A119.1, 1974 \& 1975

NO PROVISION

MI (NFPA 501B, 1973)

R 408.30626. Plans for physically handicapped.

Rule 626. Part $B$, section 8 is amended to read as follows:

8.5. Plans for physically handicapped. All manufacturers shipping into or building in the State of Michigan shall have mobile home floor plans available providing barrier free design for persons with physical limitations. These plans shall conform with the following section of Part 4 of the Michigan Construction Code, if and as required by the purchaser:

Section 318.5

Section 318.78, parts (a), (b), (c) except 318.74 and $318.75,(d),(e)$ and (f)。

Section 318.79 except first sentence and reference to 318.11 and 318.12, (a), (b), (c) and $(d)$.

Sections $614.2,617.1,617.2,617.3,627.1,627.2,627.3$ and 627.4 .

Ref: Department of Labor, Construction Code Comission, Mobile Home Code, Emergency Rules, Part 6, dated May 29, 1974.

\section{Mobile Home Fire Warning Equipment}

ANSI A119.1, 1975

9.1 General. At least one listed smoke detector (which may be a single station alarm device) shall be installed in each mobile home.

NOTE: A "smoke detector" is a device which detects visible or invisible particles of combustion. A single station alarm device is an assembly incorporating a detector and an alarm sounding device in one unit, operated from a power supply either in the unit or obtained at the point of installation.

Detectors shall operate from an AC, monitored battery, or combination AC/battery power source.

9.2 Smoke Detector Location. Smoke detector(s) shall be located outside of bedrooms, in a hallway or space communicating thereto, on or near the ceiling, and shall be installed in accordance with the manufacturer's instructions, Mobile homes having bedrooms separated by any one or combination of common use areas, such as a kitchen, dining room, living, or family room (but not a bathroom or utility room), shall have at least two detectors. 
9.3 Alarm Sounding Device. Every smoke-detecting device shall cause the operation of an alarm signaling device or devices which shall be clearly audible in all bedrooms with all intervening doors closed.

9.3.1 All alarm sounding devices shall be rated not less than 85 decibels at 10 feet.

ANSI A119.1, 1974

\section{Mobile Home Fire Warning Equipment}

9.1 At least one listed, automatic smoke detector (which may be a. single-station alarm device) shall be installed in each mobile home outside each sleeping area to warn occupants of the presence of any fire condition. Detectors requiring a light source for operation shall have an audible trouble signal on failure of the light source, but such failure shall not cause an alarm. Detectors not requiring a light source for operation shall have either a visible light to indicate operability or an audible trouble signal. Audible trouble signals shall be designed to operate at least every minute for seven consecutive days. The alarm signaling device shall emit not less than 85 decibels at 10 feet. Detectors shall be located on or near the ceiling and installed in accordance with the manufacturer's instruc-. tions. [See NFPA Standard for the Installation, Maintenance and Use of Household Fire Warning Equipment (NFPA No. 74--1972).]

AK (ANSI A119.1, 1972)

3 AAC 36.190. Fire Detection System. (a) Mobile homes shall be provided with approved detectors of products of combustion other than heat. The detector(s) sha11 be mounted on the ceiling or wall at a point centrally located in a corridor or area giving access to rooms used for sleeping purposes. When there is more than one sleeping area; for example, front and rear bedrooms, two detectors shall be provided. When wall mounted, the detector shall be located within 12 inches of the ceiling. When actuated, the detector shall provide an alarm suitable to awaken sleeping occupants.

(b) Detectors of products of combustion other than heat shall be approved by the Department of Public Safety, Division of Fire Prevention or Underwriter's Laboratories, Inc., based on Standard Subject 168, issued July 1962. (Eff. 9/12/72, Reg. 43)

Authority: AS 45.30.010(a)

Ref: Chapter 36, Standards for Mobile Homes, Article 2, Construction Standards.

AZ (NFPA 501B, 1973)

Smoke Detector or Early Warning System as per NFPA-501B, 1973, Part B, Section 9, ANSI 119.1 (1973) (As adopted September 25, 1973)

A device which detects visible or invisible products of combustion.

A. Ninety (90) days after the adoption of the Rule 11, all mobile homes shall be equipped with a smoke detector device which is approved by an approved testing and/or 1isting agency, and the manufacturer shall submit same to this Division for approval.

B. In mobile homes that have bedrooms at opposite ends, there shall be one smoke detector device installed for each end of the mobile home, adjacent to the bedrooms as per Section 9.1 of NFPA-501B, 1973, as amended January 15, 1974.

Ref: Division of Building Codes; Rules, Regulations, and Standards, Title 44, Chapter 11, Article 7. 
R 408.30631. Mobile home fire protection equipment.

Rule 631. Part B, section 9 is amended to read as follows:

9. Mobile home fire protection equipment.

9.1. General. At least one listed smoke-and-rapid-heat-rise detector (which may be a single station alarm device) shall be installed in each mobile home. Detectors shall operate from an AC, monitored battery, or combination AC/battery power source.

9.2. Smoke detector location. Smoke-and-rapid-heat-rise detector(s) shall be located outside of bedrooms, in a hallway or space communicating thereto, surface-mounted on or near the celling, and shall be installed in accordance with the manufacturer's 1nstructions. Mobile homes having bedrooms separated by any one or combination of common use areas, such as a kitchen, dining room, living room, or fanlly room (but not a bathroom or utility room) shall have at least two detectors.

9.3. Alarm sounding device. Every detecting device ahall cause the operation of an alarm signaling device or devices which shall be clearly audible in all bedrooms with all intervening doors closed.

10 feet.

9.3.1. All alarm sounding devices shall be rated not less than 85 decibels at

9.4. Detector trouble signals. Detectors requiring a light source for operation shall have an audible trouble signal on failure of the light source, but such failure shall not cause an alarm. Detectors not requiring a light source for operation shall have either a visible light to indicate operability or an audible trouble signal. Audible trouble signals shall be designed to operate at least every minute for seven consecutive days.

9.5. Testing. The mobile home manufacturer shall provide instructions (supplied by the device manufacturer) for the periodic testing of the detector(s).

9.6. Fire extinguisher. The manufacturer shall provide a listed portable fire extinguisher labeled as suitable for Class A, B and C fires (multipurpose dry chemical type). Alternatively, a listed extinguisher having a label for Class $B$ and $C$ fires (carbon dioxide or dry chemical type) shall be provided and elther a 1isted extingulsher for, or a hose line for handing Class A fires in the balance of the mobile home. The extinguisher shall be positioned in the kitchen area, In a convenient location, read1ly accessible but not necessarily visible.

Raf: Department of Labor, Construction Code Comisston, Moblle Home Code, Emergancy Rules, Part 6, dated May 29, 1974.

NC (ANSI A119.1, 1974)

Section 9.1 - Fire Warning Equipment - Add the following sentence at end of section: "SMOKE DETECTORS SHALL BE EI.ECTRICALLY OPERATED AND THE PRIMARY SOURCE OF POWER FOR DETECTORS INSTALLED IN NEW STRUCTURES SHALL BE TAKEN FROM THE HOUSE ELECTRICAL CURRENT."

Ref: North Carolina State Building Code Council adoption of "State of North Carolina Standards for Mobile Homes" with amendments; [ANSI AII9.1-74 (NFPA B-73) adopted March 12, 1974]. 


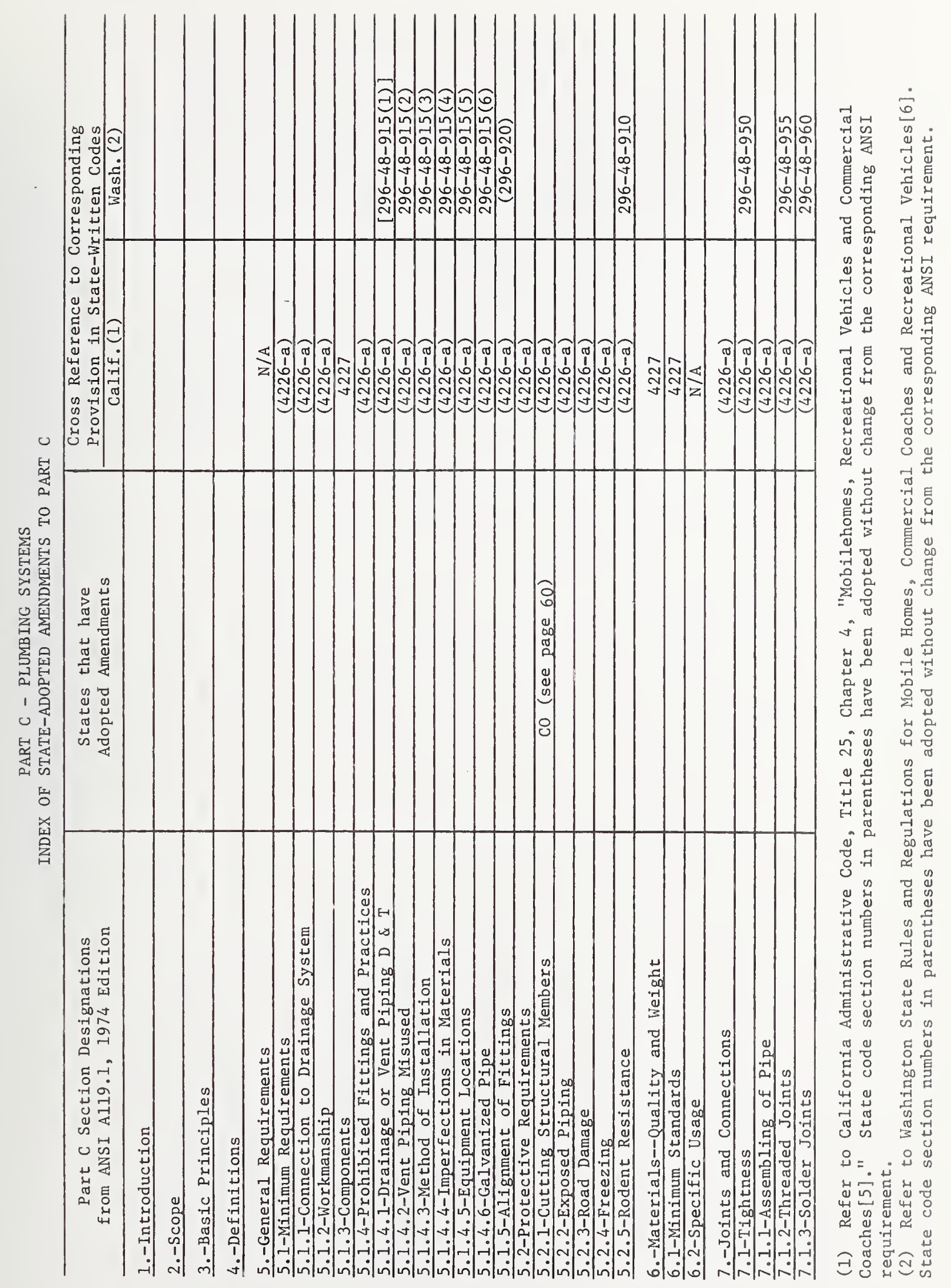














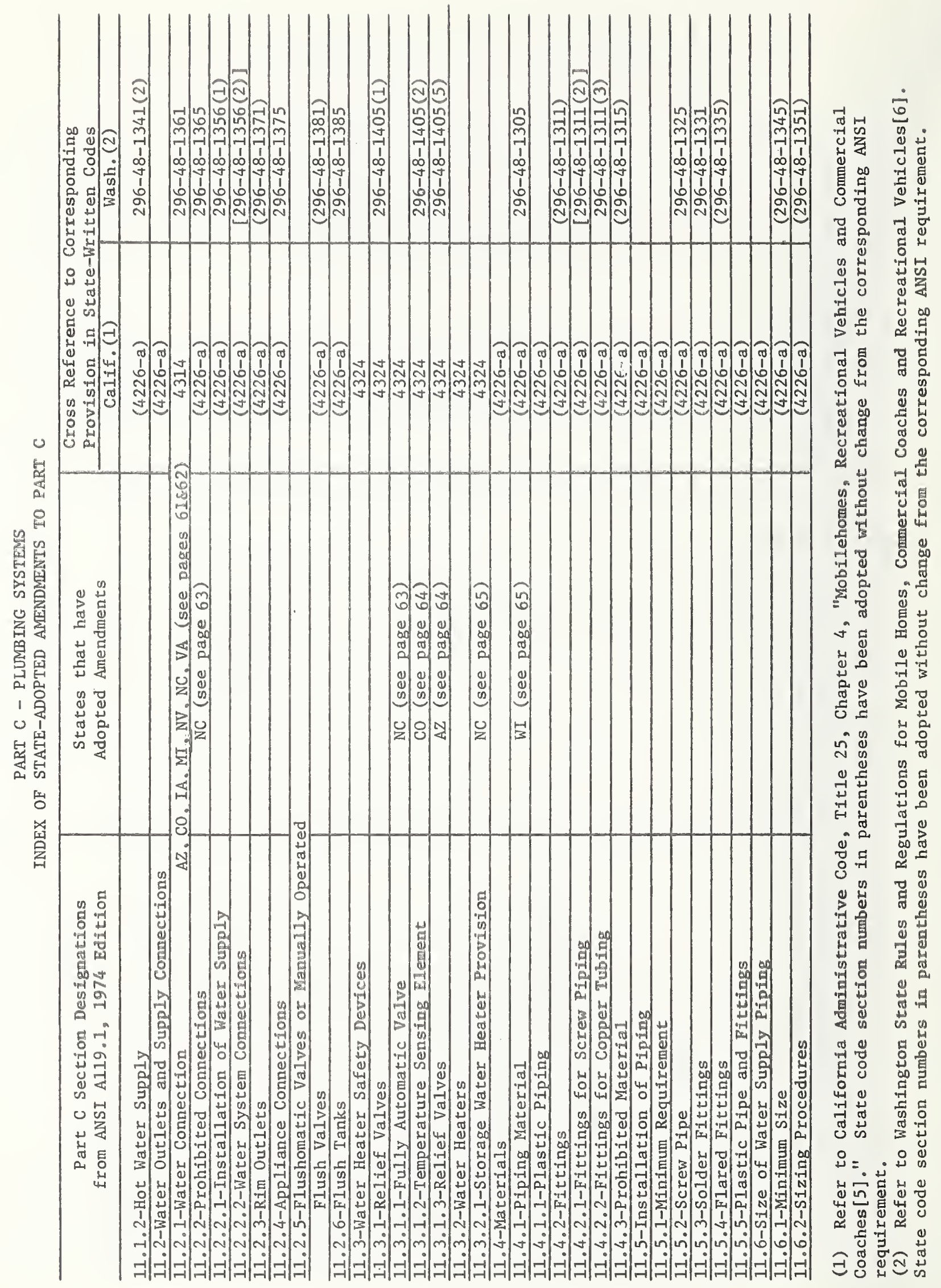




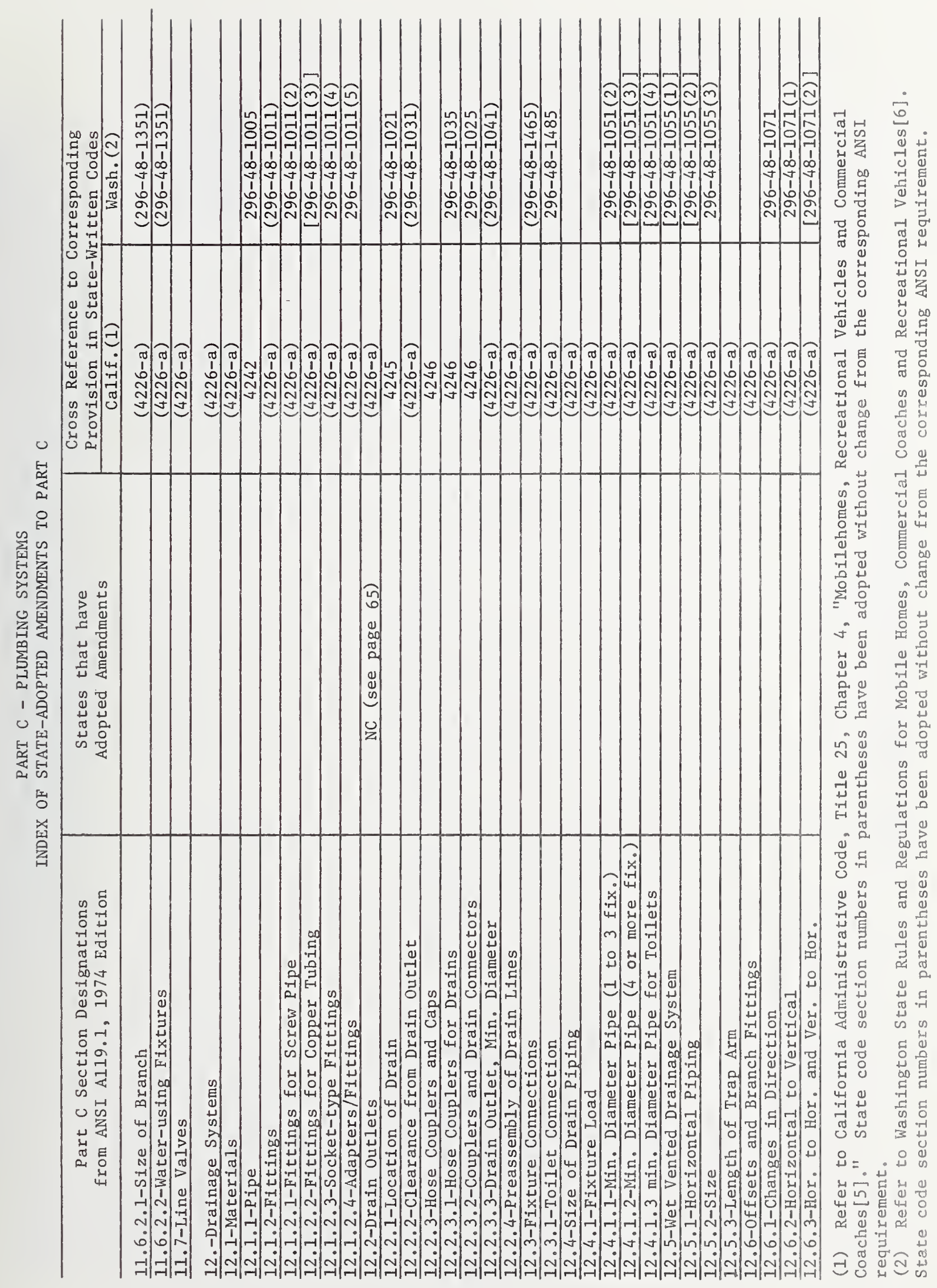




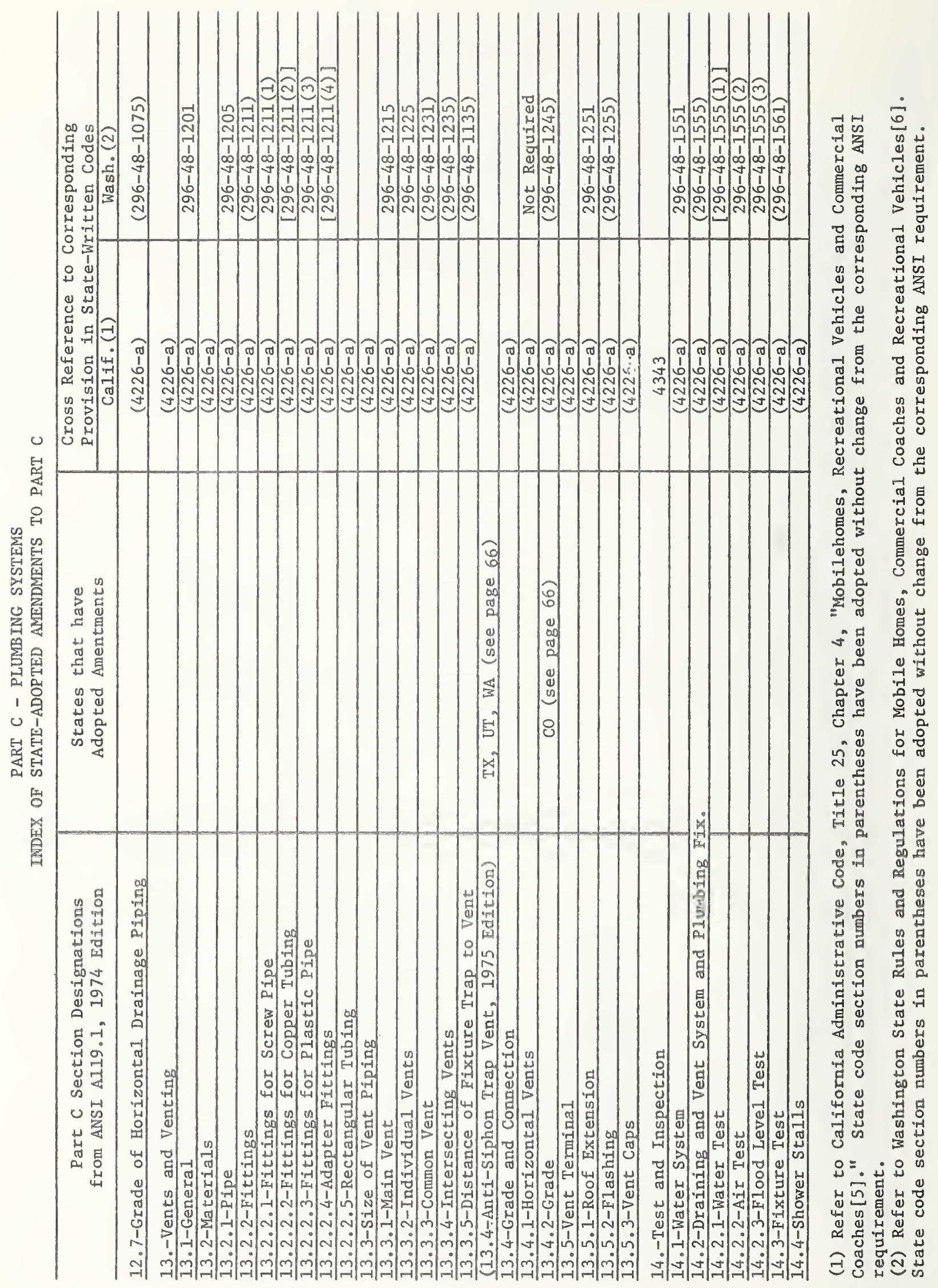




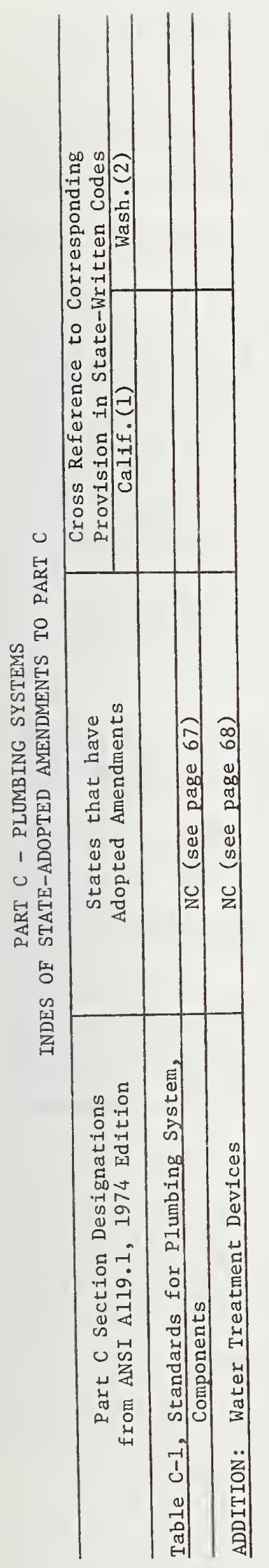

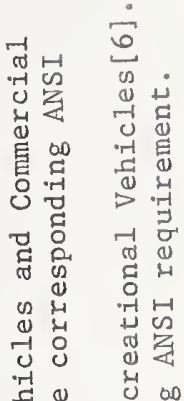

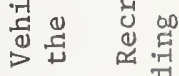

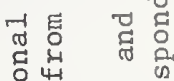

吕 41 \&

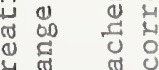

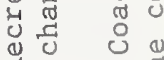

य

के

弯

造 3 至 0

멍 ठ

只品 会

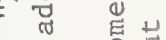

†덩 证 올

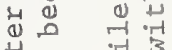

品䓃

元告

กิ $\begin{array}{lll}0 & 0 & 0 \\ 0 & 0 & 0 \\ 0\end{array}$

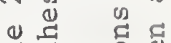

品范

故

(1)

०त लि

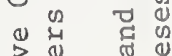

苞 क

(4)

क 3 出

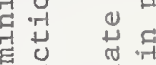

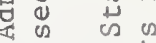

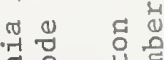

过 㗁

फ

㲻䓠

욤요

4 둥

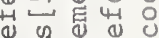

व

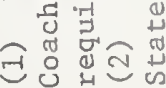




\section{PART C - PLUMBING SYSTEMS}

5.2.1 Cutting Structural Members

ANSI A119.1, 1974 \& 1975

5.2.1 Cutting Structural Members. Structural members shall not be unnecessarily or carelessly weakened by cutting or notching.

NOTE: See Paragraphs 6.6 .1 and 6.9 .1 of Part B.

CO (ANSI A119.1, 1974)

(4) Amend Section 5.2.1, Part C to delete the phrase "unnecessarily or carelessly".

Ref: Notice of Adoption of Rules Regarding Construction Standards; Colorado Division of Housing; December 19, 1974.

\subsubsection{TRAPS REQUIRED}

ANS I A119.1, $1974 \& 1975$

8.1.1 Traps Regulred. Each plumbing fixture, except listed tollets, shall be separately trapped by approved water seal "p" traps. All traps shall be effectively vented.

AZ (NFPA 501B, 1973)

A11 "P" traps shall be removable with two-threaded nuts. (As amended January 15, 1974) Ref: Division of Building Codes; Rules, Regulations and standards, Title 44, Chapter 11, Article 7 .

\section{$9,2,3,1$ DishWASHing Machines}

ANS I A119.1, 1974 \& 1975

9.2.3.1 Dishwashing machine shall not be directly connected to any waste piping, but shall discharge its waste through a fixed air gap installed above the machine. The drain connection from the air gap may connect to an individual trap, to a directional fitting installed In the sink tallpiece, or to the opening provided on the inlet side of a food waste disposal unit.

CO (ANSI A119.1, 1974)

(5) Delete Section 9.2.3.1, Part C, and substitute:

9.2.3.1: "Dishwashing machine shal1 not be directly connected to any waste piping, but shall discharge its waste through an approved fixed air gap installed above the machine. The drain connection from the alr gap may connect to an individual trap, to a directional fitting installed in the sink tailplece, or the opening provided on the inlet side of a food waste disposal unit."

Ref: Notice of Adoption of Rules Regarding Construction Standards; Colorado Division of Housing, December 19, 1974. 
ANSI A119.1, 1974 \& 1975

10. 1 Strains and Stresses. Piping in a plumbing system shall be installed without undue strains and stresses, and provision shall be made for expansion, contraction, and structural settlement.

10.2 Piping Supports. Piping shall be secured at sufficiently close intervals to keep the pipe in alignment and carry the weight of the pipe and contents.

\section{WI (NFPA 501B, 1973)}

(c) Supports. All piping shall be supported to prevent undue strains upon connections or fixtures and shall be so aligned and graded that the entire system or parts thereof can be controlled and drained. The formation of traps or sags in water piping shall be avoided where possible. When unavoidable, such sags, traps, or inverts shall have provisions for properly draining same.

(e) Freezing. All piping and fixtures subject to freezing temperatures shall be insulated or protected to prevent freezing under normal occupancy. All water distribution piping shall be aligned and graded to permit draining.

Ref: Wisconsin Administrative Code, Rules of Department of Health and Social Services; Plumbing, Chapter H62, "Design, Construction, Installation, Supervision and Inspection of Plumbing." Letter dated September 27, 1974, Department of Health and Social Services.

\subsubsection{WATER CONNECTION}

ANSI A119.1, 1975

11.2.1 Water Connection. Each mobile home with a water distribution system shall be equipped with a 3/4-inch threaded inlet connection located within the rear half of the length of the mobile home. This connection shall be tagged or marked "Fresh Water Connection" (or "Fresh Water Fill"). A matching cap or plug shall be provided to seal the water inlet when it is not in use, and shall be permanently attached to the mobile home or water supply piping.

ANSI A119.1, 1974

11.2. 1 Water Connection. Each mobile home with a water distribution system shall be equipped with a 3/4-inch inlet coupling located within the rear half of the length of the mobile home. This inlet should be located as near as possible to a point $30 \mathrm{ft}$. from the front of the mobile home, and left (road side) of the center line. This connection shall be tagged or marked "Fresh Water Connection" (or "Fresh Water Fill"). A matching cap or plug shall be provided to seal the water inlet when it is not in use, and shall be attached with a substantial chain.

\section{AZ (NFPA 501B, 1973)}

(As amended January 15, 1974)

A master cold water shut-off valve (3/4") shall be installed on the main feeder line in an accessible area. If a shut-off valve is already in existence at the exterior facility in an accessible area, a new one need not be installed.

Ref: Division of Building Codes; Rules, Regulations and Standards, Title 44, Chapter 1., Article 7. 
(6) Add to Section 11.2.1, Part C:

"A master cold water shut-off full-flow valve shall be installed at the water connector in an accessible area."

Ref: Notice of Adoption of Rules Regarding Construction Standards; Colorado Diviston of Housing; December 19, 2974.

IA (ANSI A119.1, 1974)

Add to 11.2 .1 of Part C - A master cold water shut-off full-flow valve shall be installed on the main feeder line an an accessible area.

Ref: Iowa state Building Code, Administrative Section, (I-14) June I, 1974.

MI (NFPA 501B, 1973)

Rule 636. Part $C$, section 11.2 .1 is amended to read as follows:

11.2.1. Water connection. Each mobile home with a water distribution system shall be equipped with a $3 / 4$ inch inlet coupling located within the rear half of the length of the mobile home. This inlet should be located as near as possible to a point 30 feet from the front of the mobile home, and left (road side) of the center 1ine. This connection shall be tagged or marked "Fregh Water Connection" (or "Fresh Water Fil1"). A matching cap or plug shall be ptovided to seal the water inlet when it is not in use, and ahall be attached with a gubstantil chaln. Whan used, heat tape shall be of the 11sted type, tested and labeled by a natonally recogndzed testine agency.

Ref: Department of Labor, Construction Code Commisston, Mobile Home Code, Emergency Rules, part 6, Mobjle Home Code, Rule 636, May 29, 1974.

\section{NV (NFPA 501B, 1973)}

220. WATER SHUTOFF VAIVES REQUIRED. Every mobile home manufactured after the effective date of these regulations, sold or offered for sale in this state, shall be equipped with an easily accessible water shutoff valve for each water appliance.

Ref: Nevada State Fire Marshal Division, Mobile Home and Manufactured Building Section, Regulations for Mobile Homes and Travel Trailers, November 1973.

NC (ANSI A119.1, 1974)

Section 11.2.1 - Water Connection - Add the following sentence which was deleted from the 1969 Edition: "A MASTER COLD WATER SHUT OFF GATE VALVE SHALL BE INSTALLED ON THE MAIN FEEDER LIVE IN AN ACCESSIBLE AREA."

Ref: North Carolina State Building Code Council adoption of "State of North Carolina Standards for Mobile Homes," with amendments: [ANSI AII9.I-74 (NFPA B-73) adopted March I2, 1974].

VA (ANSI A119.1, 1974)

ANSI A119.1 - 1974 is acceptable, with the following amendment for mobile homes hereafter produced:

Part $C$, Section 11.2.1 - Water Connection - Add the following sentence: A master cold water shut off full flow valve shall be installed on the main feeder line in an accessible area.

Ref: Amendments and Modifications to the Virginia Industrialized Building Unit and Mobile Home Safety Regulations, JuIy 29, I974. 
Exerpt frcm Minutes of NCSBCS (National Conference of States on Building Codes and Standards) Reciprocity Committee Meeting; Salt Lake City, Utah; February 28, 1974:

The following items were discussed under new business.

Mr. Mullen reminded the Committee members that ANSI Al19.1 - 1973 Edition was effective on January 17, 1974, and the Committee had established a policy of adopting that Standard within six months. . . and not later than one year. He provided a review of the amendments that had been approved by the Committee which amends the 1973 Edition by adding a sentence to 11.2.1, Part C, as follows: "A master cold water shut off full flow valve shall be installed on the main feeder line in an accessible area."

This amendment was submitted and will become a part of ANSI Al19.1 Standard. Motion made by Mullen, seconded by Betz, that this amendment be adopted by states and to, again, submit the proposed amendment at the Austin meeting for submittal to the ANSI Al19.1 Committee, if it has not been passed by the Committee prior to that time.

\section{2 .2 Prohibited Connections}

ANSI A119.1, 1974 \& 1975

\subsubsection{Prohibited Connections}

11.2.2.1 The installation of potable water supply piping or fixture or appliance connections shall be made in a manner to preclude the possibility of backflow.

NC (ANSI A119.1, 1974)

Locations below the level of the sewer. Section 814.1 of the State Plumbing Code shall be consulted when fixtures are located below the level of the sewer.

\subsection{Fixtures Subject to Backflow.}

The installation of backwater devices shall be in accordance with lawful requirements of the plumbing official having jurisdiction over the public sewer system. Where fixtures are located below the level of the top of the first upstream manhole, said fixtures shall be protected by a backwater valve.

Ref: State of North Carolina Regulations for Mobile Homes, 1972 Edition.

\section{3 .1 .1 ReLief VaLVes}

ANSI A119.1, $1974 \quad \& \quad 1975$

11.3.1 Relief Valves

11.3.1.1 All water heaters shall be installed with approved and listed fully automatic valve or valves designed to provide temperature and pressure relief.

NC (ANSI A119.1, 1974)

Section 11.3 Safety Devices

Section 66-27.1 through 66-27.6 of the General Statutes requirements on automatic hot water tanks to have installed thereon by the manufacturer of such tank an American Society of Mechanical Engineers and National Board of Boiler and Pressure Vessels Inspector's Temperature Relief Valve.

NOTE: U.L. Labeled Mobile Homes are acceptable without local inspection of relief valve. Ref: State of North Carolina Regulations for Mobile Homes, 1972 Edition. 


\section{$11.3,1.2$ RELIEF VALVES}

ANS I A119.1, 1975

1.3.1.2 Any temperature relief valve or combined pressure and temperature relief valve Inttalled for thio purpose ghall have the temperature sensing element immersed in the hotteot water within the upper 6 Inches of the tank. It shall be set to gtart relieving at a pressure of $125 \mathrm{psi}$ or the rated working pressure of the tank whichever is lower and at or below a water temperature of $210^{\circ} \mathrm{F}$.

ANSI A119.1, 1974

11.3.1.2 Any temperature rellef valve or combined pressure and temperature relief valve installed for this purpose shall have the temperature sensing element immersed in the hottest water within the upper 6 inches of the tank. It shall be set to start relieving at a pressure not exceeding the rated working pressure of the tank and at or below a water temperature of 210 degrees $F$.

CO (ANSI A119.1, 1974)

(7) Add to Section 11.3.1.2, Part C:

"The temperature relief device shall be of the self-closing type."

Ref: Notice of Adoption of Rules Regarding Construction Standards; Colorado Division of Housing; December 19, 1974.

\section{$11.3,1.3$ RELIEF VALVES}

ANSI A119.1, 1975

11.3.1.3. Relief valves shall be provided with full-sized drains which shall be directed downward and discharge beneath the mobile home. Drain lines shall be of a materlal listed for hot water distribution and shall drain fully by gravity, shall not be trapped, and shall not have their outlets threaded.

\section{ANSI A119.1, 1974}

11.3.1.3 Rellef valves shall be provided with full-sized drains which shall extend outside, directed downward and terminate beneath the mobile home. Drain lines shall be of a material listed for hot water distribution and shall drain fully by gravity, shall not be trapped and shall not have their outlets threaded.

\section{AZ (NFPA 501B, 1973)}

Hot water relief valves draining downward shall terminate outside (beneath) the mobile home for a minimum of aix Inches below floor level unthreaded at the terminal end.

Ref: Division of Building Codes, Rules, Regulations and standards, Title 44, Chapter 11, Article 7.

\subsubsection{Storage Water Heater}

ANSI A119.1, 1975

NO PROVISION 
ANSI A119.1, 1974

11.3.2.1 Each storage water heater shall be provided with a three-quarter (3/4)-inch pipe tapping for a combined pressure-temperature relief valve within the top 6 inches of the tank. The tapping shall be in a location which will permit easy access for installing, testing, and maintenance of the valve.

NC (ANSI A119.1, 1974)

Section 11.3.2.1 - Water Heaters - Add the following sentence which was deleted from the 1969 Edition: "EACH PRESSURE TANK SHALL BE CAPABLE OF WITHSTANDING 200 PSI MINIMUM TEST WATER PRESSURE." No minimum test pressure required in 1973 Edition.

Ref: North Carolina State Building Code Council adoption of "State of North Carolina Standards for Mobile Homes," with amendments, [ANSI Al19.1-74 (NFPA B-73) adopted March 12, 1974.

\subsubsection{Piping Material}

ANSI A119.1, 1974 \& 1975

11.4.1 Piping Material. Water pipe shall be of standard weight brass, galvanized wrought iron, galvanized steel, Type K, L or M copper tubing, approved or listed plastic, or other approved or listed material.

WI (NFPA 501B, 1973)

(11) Drainage Systems. (a) Materials. 1. Piping. Drainage piping shall be standard weight galvanized steel; wrought iron; cast iron; brass; K, M, L or DWV type copper; ABS or PVC plastic or other materials approved by the department.

a. ABS plastic pipe and fitting materials shall be type 1, grade 2, schedule 40 DWV or heavier, as defined in A.S.T.M. specifications D 1788-68 and D 2661-68. They sha11 also bear the NSF (National Sanitation Foundation) Seal of Approval for drain, waste and vent systems.

Ref: Wisconsin Administrative Code, Rules of Department of Health and Social Services; Plumbing, Chapter H-62, "Design, Construction, Installations, Supervision and Inspection of Plumbing. Letter dated September 27, 1974, Department of Health and Social Services.

\subsection{DRAin OUTLETS}

ANSI A119.1, $1974 \& 1975$

\subsection{Drain Outlets}

12.2.1 Location of Drain. Each mobile home shall have only one drain outlet which shall terminate in the rear half section. This outlet should be located as close as possible to a point $40 \mathrm{ft}$. from the front of the mobile home.

NC (ANS I A119.1, 1974)

Drainage System

No sewage, waste water or any other effluent shall be allowed to be deposited on the surface of the ground. Consult regular health regulations for these requirements. Ref: State of North Carolina, Regulations for Mobile Homes, 1972 Edition. 


\subsection{Anti-Siphon Trap Vent Devices}

ANSI AI19.1, 1975

13.4 Anti-Siphon Trap Vent

13.4.1 Ant1-Siphon Trap Vent Devices. Where an ant1-s1phon trap vent device is used as a secondary vent, it shall be installed in accordance with the terms of its listing and shall be accessible. The lowest point of the valve seal when in the normally closed position

shall not be less than 6 inches above the fixture tee. The toilet shall be vented in accordance with Paragraph 13.3.1. Only anti-siphon trap vent devices which have been approved shall be Installed.

13.4.2 Not more than two fixtures individually protected by anti-siphon trap vent devices shall be drained by a common $11 / 2$-inch drain.

13.4.3 Three or more fixtures individually protected by anti-siphon trap vent devices shall be drained by a common 2-inch drain.

ANSI A119.1, 1974

NO PROVISION

IX (ANSI A119.1, 1974)

Documented information not received in time for inclusion in this report. The following information was given verbally:

The Performance Certification Board for Mobile Homes approves and 1ists individual manufacturers' products for use as secondary vents only.

\section{UT (NFPA 501B, 1973, Currently in Effect)}

Utah anticipates adopting NFPA 501B, 1974 with the effective date to be tentatively January 15, 1975. They intend to delete Section 13.4 .

Ref: Letter from Utah Mobile Homes and Recreational Vehicles Division, October 8, 1974.

\section{WA (STATE CODE)}

"We do not recognize the Ant1-Siphon Trap Vent Device as permitted by ANSI, Part C, $13.4 .1 . "$

Ref: Letter from State of Washington Factory-Built Housing, Mobile Home and Recreational Vehicle Section; December 6, 1974.

\section{4 .2 GRADE}

ANSI A119.1, 1974 (Requirement is designated 13.5.2 in 1975 Edition)

13.4.2 Grade. Vents shall be level or so designed to drain back to the drainage system by gravity.

CO (ANSI A119.1, 1974)

(8) Amend Section 13.4.2, Part C to read:

"Vents shall be designed to drain back to the drainage system by gravity at a pitch of not less than one-eighth inch per foot."

Ref: Notice of Adoption of Rules Regarding Construction Standards; Colorado Division of Housing; December 19, 1974. 
Extracted from Table C1-ANSI A119.1-1974

\begin{tabular}{|c|c|c|c|c|}
\hline Materials & ANSI & ASTM & FS & $\begin{array}{c}\text { Other } \\
\text { Standards }\end{array}$ \\
\hline $\begin{array}{l}\text { Nonferrous Pipe and Fittings (con } \\
\text { Cast Bronze Threaded Fittings, } \\
150 \text { and } 300 \text { lb. }\end{array}$ & $\begin{array}{r}\text { B16.15 } \\
-1971\end{array}$ & & & \\
\hline $\begin{array}{l}\text { Plastic Pipe and Fittings } \\
\text { ABS Plastic Drain, Waste, and } \\
\text { Vent Pipe and Fittings }\end{array}$ & & $\begin{array}{l}D 2661 \\
-1973\end{array}$ & $\begin{array}{l}\mathrm{L}-\mathrm{P} \\
322 \mathrm{~B} \\
-1973\end{array}$ & $\begin{array}{l}\text { IAPMO PS } \\
17-71 \\
\text { NSF-14 } \\
1970\end{array}$ \\
\hline $\begin{array}{l}\text { PVC Plastic Drain, Waste, and } \\
\text { Vent Pipe and Fittings }\end{array}$ & & $\begin{array}{l}\text { D2665 } \\
-1973\end{array}$ & $\begin{array}{l}\mathrm{L}-\mathrm{P}- \\
320 \mathrm{~B} \\
-1973\end{array}$ & $\begin{array}{l}\text { IAPMO PS } \\
27-69 \\
\text { NSF-14 } \\
1970\end{array}$ \\
\hline $\begin{array}{l}\text { Chlorinated Poly (Vinyl/Chloride) } \\
\text { (CPVC) Plastic Hot Water } \\
\text { Distribution Systems }\end{array}$ & & $\begin{array}{l}\mathrm{D} 2846- \\
1973\end{array}$ & & $\begin{array}{l}\text { NSF-14 } \\
1970\end{array}$ \\
\hline $\begin{array}{l}\text { Polybutylene (PB) Plastic Pipe } \\
\text { (SDR-PR) }\end{array}$ & $\begin{array}{l}\mathrm{D} 2662- \\
1973\end{array}$ & & & \\
\hline $\begin{array}{l}\text { Polybutylene (PB) Plastic Hot } \\
\text { Water Distribution Systems }\end{array}$ & $\begin{array}{l}\text { D3309 } \\
-1974\end{array}$ & & & \\
\hline $\begin{array}{l}\text { Miscellaneous } \\
\text { Pipe Nipples, Threaded }\end{array}$ & & & $\begin{array}{l}\mathrm{WW}-\mathrm{N}- \\
351 \mathrm{~B}(1) \\
-1970\end{array}$ & \\
\hline $\begin{array}{l}\text { Rubber Gaskets for Cast Iron } \\
\text { Soll Pipe Fittings }\end{array}$ & & $\begin{array}{l}C 564 \\
-1970\end{array}$ & & \\
\hline Backflow Prevention Devices & & & & $\begin{array}{l}\text { IAPMO PS } \\
31-71\end{array}$ \\
\hline $\begin{array}{l}\text { Valve, Bronze, Gate } 125-150 \\
\text { and } 200 \text { Pound }\end{array}$ & & & $\begin{array}{l}\text { WW-V } \\
54 D^{\prime} 73\end{array}$ & \\
\hline $\begin{array}{l}\text { Valve, Cast-Iron Gate, Threaded } \\
\text { and Flanged }\end{array}$ & & & $\begin{array}{l}\text { WW-V- } \\
58 B^{\prime} 71\end{array}$ & \\
\hline $\begin{array}{l}\text { Plumbing--Fixture-Setting } \\
\text { Compound }\end{array}$ & & & $\begin{array}{l}\mathrm{HH}-\mathrm{C}- \\
536 \mathrm{~A}^{\prime} 54\end{array}$ & \\
\hline Cast Brass and Tubing P-Traps & & & & $\begin{array}{l}\text { IAPMO PS } \\
2-66\end{array}$ \\
\hline $\begin{array}{l}\text { Relief Valves and Automatic } \\
\text { Gas Shutoff Devices for Hot } \\
\text { Water Supply Systems }\end{array}$ & $\begin{array}{l}\mathrm{Z} 21.22 \\
-1971\end{array}$ & & & \\
\hline $\begin{array}{l}\text { Solvent Cement for ABS Plastic } \\
\text { Pipe and Fittings }\end{array}$ & & $\begin{array}{l}\mathrm{D} 2235 \\
-1973\end{array}$ & & $\begin{array}{l}\text { NSF-14 } \\
1970\end{array}$ \\
\hline $\begin{array}{l}\text { Solvent Cement for PVC Plastic } \\
\text { Pipe and Fittings }\end{array}$ & & $\begin{array}{l}\mathrm{D} 2564 \\
-1973\end{array}$ & & $\begin{array}{l}\text { NSF-14 } \\
1970\end{array}$ \\
\hline Anti-Siphon Trap Vent Device & & & & $\begin{array}{l}\text { NSF }-24 \\
1972\end{array}$ \\
\hline
\end{tabular}


Table C-1 - Standards for Plumbing System Components - Delete references to Chlorinated Poly (Vinyl/Chloride) (CPVC) Plastic and other plastic pipe for hot and cold water distribution systems. The Council denied the use of CPVC for all other buildings and structures $9 / 14 / 72$ because of lack of substantiating data submitted. Among the data submitted was information that the CPVC plastic pipe had been tested to maximum of 180 degree temperature which is below the 200 degree temperature set for the hot water heater rellef valve.

Ref: North Carolina state Building Code Council adoption of "State of North Carolina Standards for Mobile Homes," with amendments; [ANSI A119.1-74 (NFPA B-73) adopted March 12, 1974.

\section{Water Treatment Devices}

ANS I A119.1, 1974

NO PROVISION

NC (ANSI A119.1, 1974)

Water Softners, Water Filters, or Other Water Treatment Devices.

Section 1213.1, Section b of the State Plumbing Code shall be consulted when these devices are needed.

\subsection{Size of Potable Water Piping.}

(b) Whenever a water filter, water softner or similar water treating device, backflow prevention device or similar device is installed in any water supply line, the pressure loss through such devices must be included in the pressure loss calculations of the system, and the water supply pipe and meter shall be adequately sized to provide for any such pressure loss.

Ref: State of North Carolina, Regulations for Mobile Homes, 1972 Edition. 


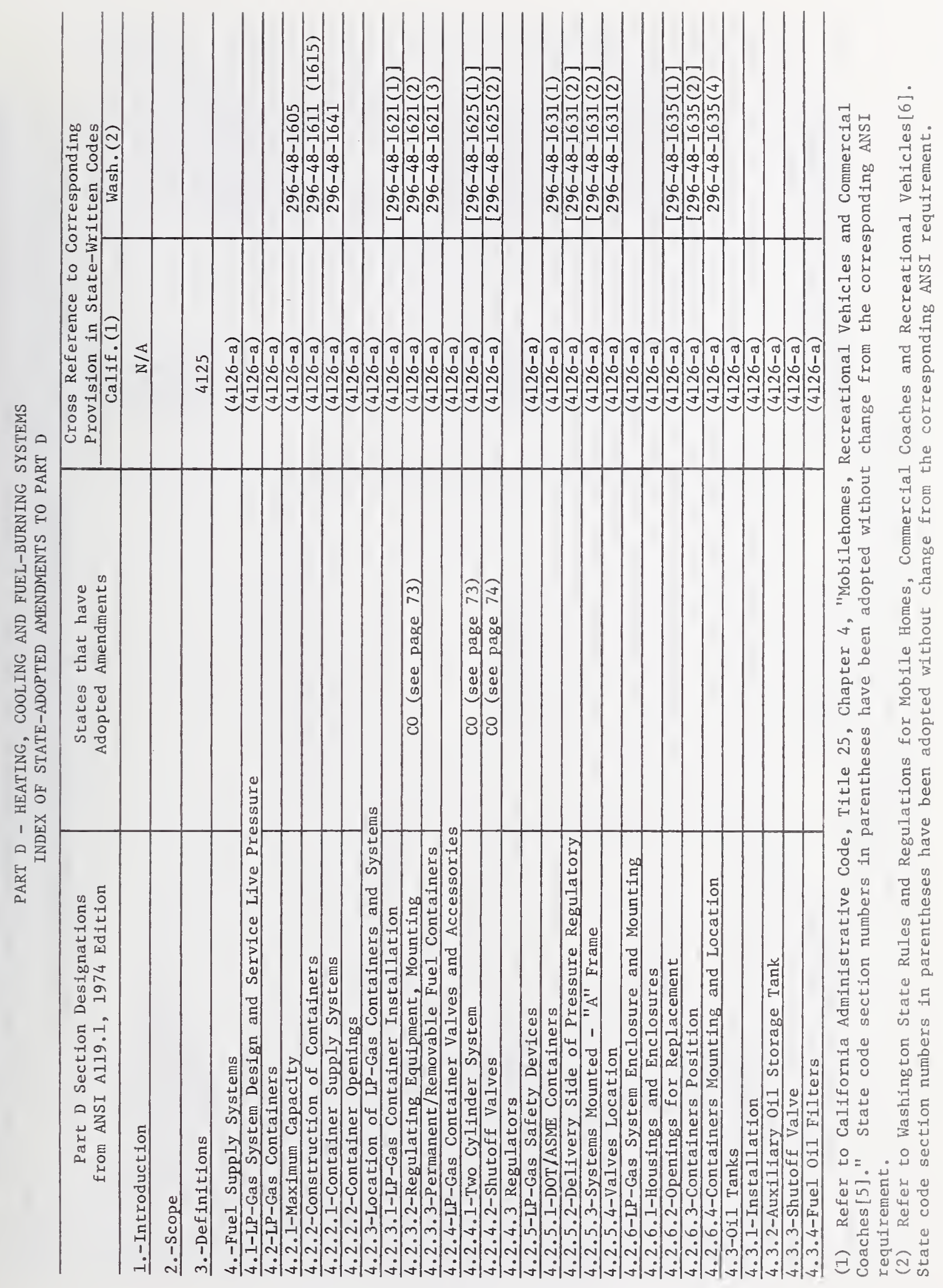









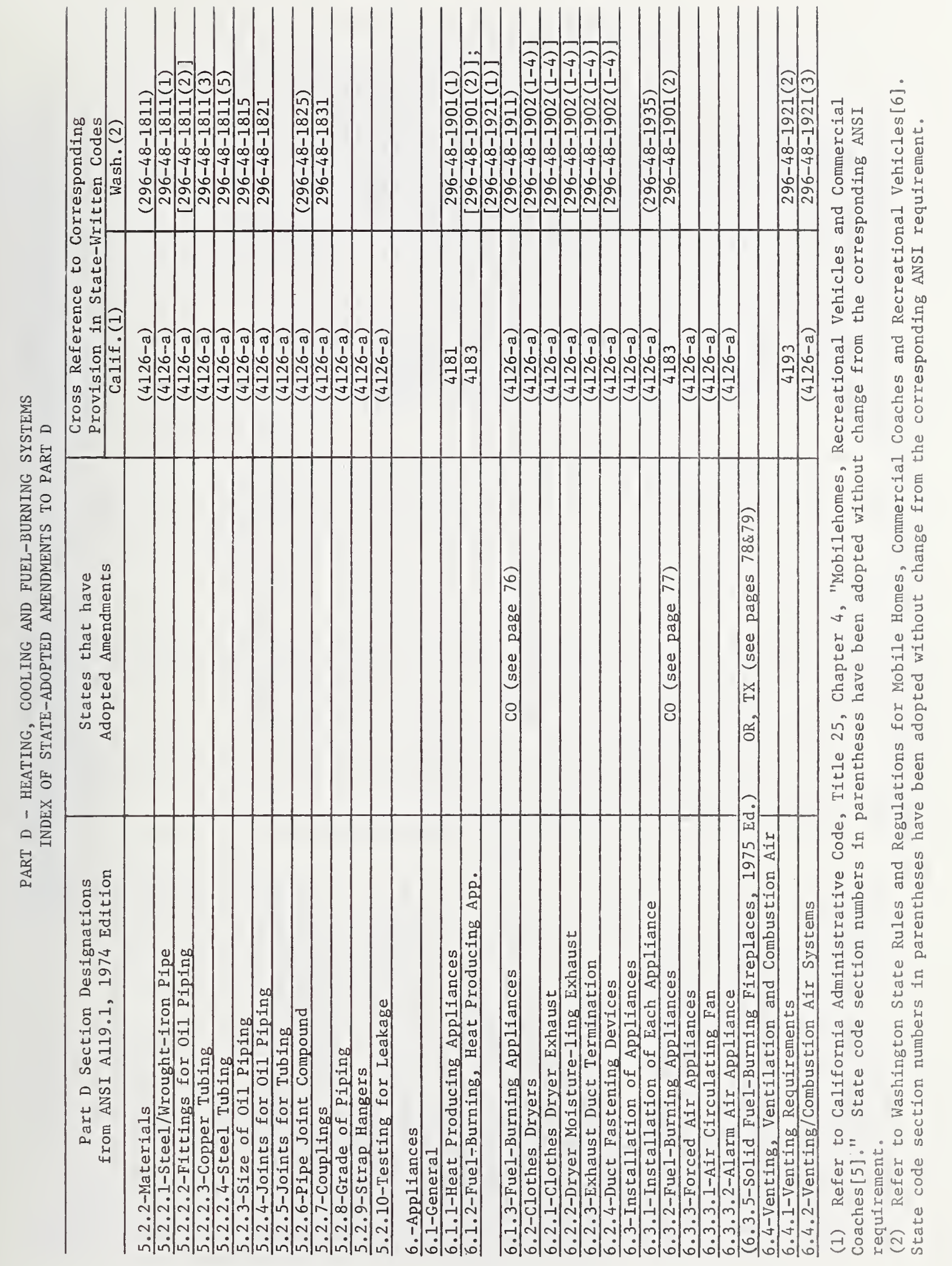




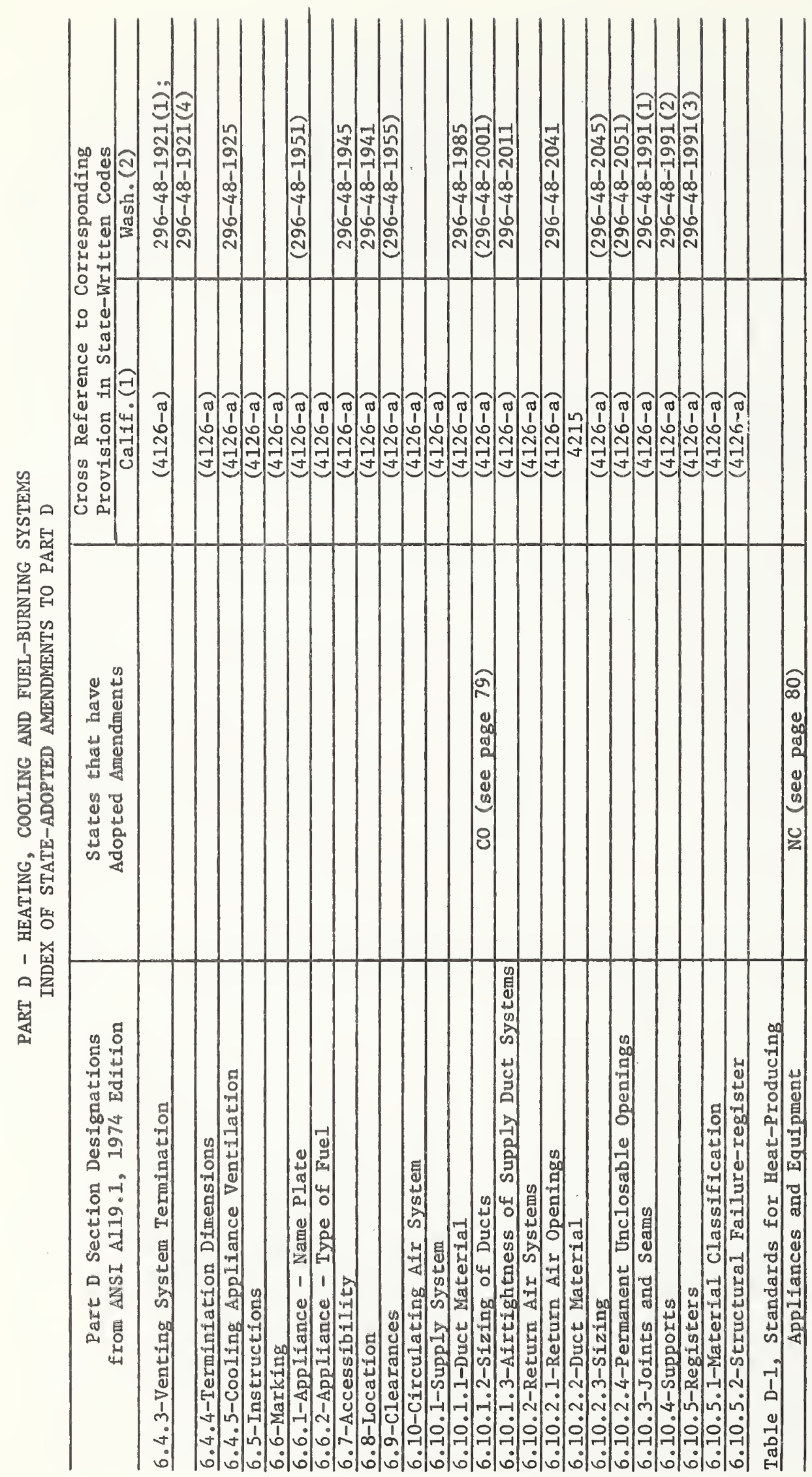






\section{PART D - HEATING SYSTEMS}

\subsubsection{Location of LP-Gas Containers and Systems}

ANSI A119.1, $1974 \& 1975$

4.2.3.2 Containers, control valves, and regulating equipment, when installed, shall be mounted on the "A" frame of the mobile home, or installed in a compartment that is vapor-

tight to the inside of the mobile home and accessible only from the outside. The compartment shall be ventilated at top and bottom to facilitate diffusion of vapors. The compartment shall be ventilated with two vents having an aggregate area of not less than two percent of the floor area of the compartment and shall open unrestricted to the outside atmosphere. The required vents shall be equally distributed between the floor and ceiling of the compartment. If the lower vent is located in the access door or wall, the bottom edge of the vent shall be flush with the floor level of the compartment. The top vent shall be located in the access door or wall with the bottom of the vent not more than 12 inches below the ceiling level of the compartment. All vents shall have an unrestricted discharge to the outside atmosphere. Access doors or panels of compartments shall not be equipped with locks or require special tools or knowledge to open.

CO (ANSI A119.1, 1974)

(9) Delete the first sentence of Section 4.2.3.2, Part D, and substitute:

"Containers, control valves, and regulating equipment, when installed shall not be installed within the mobile home."

Ref: Notice of Adoption of Rules Regarding Construction Standards; Colorado Division of Housing; December 19, 1974.

\subsubsection{LP-Gas CONTAIner VALVES AND ACCESSORIES}

ANSI A119.1, 1974 (Requirement is same for 1975 Edition except

4.2.4.1 Valves in the assembly of a two-cylinder system shall be arranged so that replacement of containers can be made without shutting off the flow of gas to the appliance(s). This provision is not to be construed as requiring an automatic change-over device.

NOTE: This provision is not to be construed as requiring an automatic change-over device.

CO (ANSI A119.1, 1974)

(10) Delete "Note" to Section 4.2.4.1, Part D.

Ref: Notice of Adoption of Rules Regarding Construction Standards; Colorado Division of Housing; December 19, 1974.

\section{$4.2,4.2$ Shutoff VALVES}

ANSI A119.1, 1975

4.2.4.2 Shutoff valves on the containers shall be protected as follows, in transit, in storage, and while being moved into final utilization:

(a) By setting into a recess of the container to prevent possibility of their being struck if container is dropped upon a flat surface, or,

(b) By ventilated cap or collar, fastened to the container, capable of withstanding a blow from any direction equivalent to that of a 30-pound weight dropped 4 feet. Construction shall be such that the blow will not be transmitted to the valve. 
ANSI A119.1, 1974

4.2.4.2 Shutoff valves on the containers shall be protected as follows, in transit, in storage, and while being moved into final utilization:

(a) By setting into a recess of the container to prevent possibility of their being struck If container is dropped upon a flat surface, or,

(b) By ventilated cap or collar, fastened to the container, capable of withstanding a blow from any direction equivalent to that of a 30-pound welght dropped 4 feet. Construction shall be such that the blow will be transmitted to the valve.

CO (ANSI AI19.1, 1974)

(11) Amend Section 4.2.4.2 (b), Part D to read:

"By vent1lated cap or collar, fastened to the container, capable of withstanding a blow from any direction equivalent to that of a 30-pound welght dropped 4 feet. Construction shall be such that the blow will not be transmitted to the valve."

Ref: Notice of Adoption of Rules Regarding Construction Standards; Colorado Division of Housing; December 19, 1974.

\section{1 .5 JOINTS FOR GAS PIPE}

ANSI A119.1, 1974 है 1975

5.1.5 Joints for Gas P1pe. All pipe joints in the piping system, unless welded or brazed, sha11 be threaded joints that comply with ANSI Standard P1pe Threads (Except Dryseal) B2.11968. Right and left nipples or couplings shall not be used. Untons, if used, shall be of ground joint type. The materlal used for welding or brazing plpe connections shall have a melting temperature in excess of $1,000^{\circ} \mathrm{F}$.

CO (ANSI A119.1, 1974)

(18) Add to Section 5.1.5, Part D:

"All threaded fittings shall be tapped tapered."

Ref: Notice of Adoption of Rules Regarding Construction Standards; Colorado Division of Housing; December 19, 1974 .

\section{5,1,13 Appliance Connections}

ANS I A119.1, 1975

5.1.13 Appliance Connectlons. All gas burning appliances shall be connected to the fuel piping. Materials as provided in Section 5.1.2 of this Part or 11sted appliance connectors shall be used. Listed applfance connectors when used shall not run through walls, floors, cellings, or partitlons. Connectors of aluminum.shall not be used outdoors.

ANSI A119.1, 1974

5.1.13 Appliance Connectlons. All gas burning appliances shall be connected to the fuel plping with materfals as provided in 5.1 .2 of this Part or with listed appliance connectors. Listed appllance connectors when used shall not run through walls, floors, cellings, or partitions. Connectors of aluminum shall not be used outdoors. 
8. In mobile homes after March 1, 1973, only approved flexible metal tubing connectors, not vinyl covered, may be used to connect a gas appliance provided:

(a) The connector does not exceed $3^{\prime}$ in length, except range connectors which may not exceed $6^{\prime}$.

(c) Connectors shall have a nominal diameter not less than that of the inlet connector to the appliance as provided by the manufacturer of the appliance and shall be of such size as to provide the total demand of the connected appliance as per the manufacturer's specifications.

(d) An approved flexible connector shall be used to connect the mobile home to the existing gas service not exceeding $3^{\prime}$ from the input of the mobile home.

Ref: Division of Building Codes; Rules, Regulations and Standards, Title 44, Chapter 11, Article 7.

\section{CO (ANSI A119.1, 1974)}

(12) Add to Section 5.1.13, Part D:

"An accessible approved gas shut-off valve shall be located at each gas burning appliance on the supply side of the approved appliance connector."

Ref: Notice of Adoption of Rules Regarding Construction Standards; Colorado Division of Housing; December 19, 1974.

NM (ANSI A119.1, 1.973)

101-ANSI Al19.1 Modification

In mobile homes only flexible tubing connectors may be used to connect a gas appliance provided:

a. The connector does not exceed $3^{\prime}$ in length, except range connectors which may not exceed $6^{\prime}$ and shall be of single length, and

c. Connectors shall have a nominal diameter not less than that of the inlet connector to the appliance as manufactured and shall be of such size as to provide the total demand of the connected appliance as per the manufacturer's specifications.

Ref: State of New Mexico, Rules, Regulations, and Standards of the Construction Industries Commission for the Mobile Home Board, August 1974.

\section{1 .14 VALVES}

ANSI A119.1, 1974 \& 1975

5.1.14 Valves. Shutoff valves used in connection with gas piping shall be of a type designed and listed for use on LP-Gas.

NOTE: Also refer to 4.1 .3 which states, "Each mobile home requiring fuel gas for any purpose shall be equipped with a fuel gas piping system that is designed for LP-Gas only or with a natural gas piping system acceptable for LP-Gas.

\section{AZ (NFPA 501B, 1973)}

(b) An approved shut-off valve is used between the gas supply outlet and such connector. Ref: State of New Mexico, Rules, Regulations and Standards of the Construction Industry Comission for the Mobile Home Board, August 1974. 
210. GAS COCKS. Every mobile home manufacfactured after the effective date of these regulations, sold or offered for sale in this state, shall be equipped with gas shutoff valves for each gas appliance, which valves shall be easily accessible and usable without tooli, In the event of an emergency.

Ref: Nevada State Fire Marshal DIvision, Moblle Home and Manufactured Bullding Section, Regulations for Moblle homes and Travel Trallers.

NM (ANSI Al19.1, 1973)

b. An approved shut-off valve is used between the gas supply outlet and such connector, and in the same room with the appliance.

Ref: State of New Mexico, Rules, Regulations and Standards of the Construction Industry Commission for the Mobile Home Board, August 1974.

\section{1 .3 APPLIANCES}

ANSI A119.1, $1974 \& 1975$

6.1.3 Fuel-burning appliances shall not be converted from one fuel to another fuel unless converted in accordance with the terms of their listing and the appliance manufacturer's instructions.

$$
\text { CO (ANSI A119.1,1974) }
$$

(13) Add to Section 6.1.3, Part D:

"A heat producing appliance shall have its input ratings reduced at the rate of $4 \%$ for each $1,000^{\circ}$ above sea level and shall be designed for a minlmum of $5,000^{\prime}$ elevation above sea level."

Ref: Notice of Adoption of Rules Regarding Construction Standards; Colorado Division of Housing; December 19, 1974.

\subsubsection{InSTALLATION OF APPLIANCES}

ANSI A.119.1, 1975

6.3.2 All fuel-burning appliances, except ranges, ovens, illuminating appliances, clothes dryers, solid fuel-burning fireplaces, and solid fuel-burning fireplace stoves, shall be installed to provide for the complete separation of the combustion system from the interior atmosphere of the mobile home. Combustion air inlets and flue gas outlets shall be listed or certified as components of the appliance. The required separation may be obtained by:

(a) The installation of direct vent system (sealed combustion system) appliances, or

(b) The installation of appliances within enclosures so as to separate the appliance combustion system and venting system from the interior atmosphere of the mobile home. There shall not be any door, removable access panel, or other opening into the enclosure from the inslde of the mobile home. Any opening for ducts, plping, wirlng, etc., shall be sealed.

ANS I A119.1, 1974

6.3.2 All fuel-burning appliances, except ranges, ovens, flluminating appliances, clothes dryers, shall be installed to provide for the complete separation of the combustion system from the interior atmosphere of the mobile home. Combustion air inlets and flue gas outlets 
shall be listed or certified as components of the appliance. The required separation may bef obtained by:

(a) The installation of direct vent system (sealed combustion system) appliances, or

(b) The installation of appliances within enclosures so as to separate the appliance combustion system and venting system from the interior atmosphere of the mobile home. There shall not be any door, removable access panel, or other opening into the enclosure from the inside of the mobile home. Any opening for ducts, piping, wiring, etc., shall be sealed.

CO (ANSI A119.1, 1974)

(14) Add to Section 6.3.2, Part D:

"Enclosures housing any gas fired appliance with open combustion systems shali be ventilated with two vents having an aggregate free area of $2 \%$ or not less than 16 sq. in. of the floor area of the compartment and shall open unrestricted to the outside atmosphere. The required vents shall be equally distributed between the floor and ceiling of the compartment. The lower vent shall be located in the access door or wall, the bottom of the vent shall be not higher than $2^{\prime \prime}$ below the flame or ignition point. The top vent shall be located in the access door or wall with the bottom of the vent not more than 12 inches below the ceiling level of the compartment. All vents shall have an unrestricted discharge to the outside atmosphere. Access doors or panels of compartments shall not be equipped with locks or require special tools or knowledge to open."

"Appliances with sealed combustion systems shall be installed in accordance with the manufacturer's recommendations."

Mobile Homes containing sealed combustion system appliances which draw their combustion air from beneath the home must have two equally-sized vents installed on opposite sides of the mobile home. The total free area of the two vents must be equal to one square inch per 1,000 BTU's per hour of total combustion air being drawn from beneath the mobile home. The vents must be attached by the manufacturer to the bottom of the floor structure and be constructed with a full-sized, unobstructed duct to extend under the mobile home a minimum of 12 inches. The vents must have a minimum vertical depth of 4 inches and must project beyond the surface of the side wall of the mobile home. These ducts should be screened or louvered and may be constructed of either 1/2" exterior grade plywood, 28 gauge galvanized metal, or equivalent aluminum.

Ref: Notice of Adoption of Rules Regarding Construction Standards; Colorado Division of Housing; December 19, 1974.

\subsection{5 .Solid Fuel-Burning Fireplace or Fireplace Stoves}

ANS I A119.1, 1975

6.3.5 Solid fuel-burning factory-built fireplaces and fireplace stoves listed for use in mobile homes may be installed in mobile homes provided they and their installation conform to 6.3.5.1. A fireplace stove shall not be considered as a heating facility for determining compliance with Paragraph 7.5 of Part B.

6.3.5.1 A solid fuel-burning fireplace or fireplace stove shall be equipped with integral door(s) or shutter(s) designed to close the fireplace or fireplace stove fire chamber opening and shall include complete means for venting through the roof, a combustion air inlet, a hearth extension, and means to securely attach the fireplace or the fireplace stove to the mobile home structure. The installation shall conform to the following paragraphs (a) to (h) inclusive:

(a) A listed factory-built chimney designed to be attached directly to the fireplace or fireplace stove shall be used. The chimney or the flue gas outlet of the fireplace or fireplace stove shall not include a damper.

(b) A fireplace or fireplace stove, air intake assembly, hearth extension, and the 
chimney shall be Installed in accordance with the terms of their 11stings and their manufacturer's instructions.

(c) The combustion alr Inlet shall conduct the air directly into the fire chamber and shall be designed to prevent material from the hearth dropping onto the area beneath the mobile home. The alr inlet shall not include a damper or other means of closure.

(d) The fireplace of fireplace stove shall not be installed in a rleeping room.

(e) Hearth extension shall be of noncombustible material not less than 3/8-1nch thick. The hearth shall extend at least 16 1nches in front of and at least 8 inches beyond each side of the flreplace or fireplace stove opening. Furthermore the hearth shall extend over the entire surface beneath a flreplace stove and beneath an elevated or overhanging fireplace.

(f) The label on each solld fuel-burning fireplace and solid fuel-burning fireplace stove shall include the following wording: FOR USE WITH SOLID FUEL ONLY.

(g) The chimney shall be provided with a spark arrester securely attached to the chimney. The net free area of the arrester shall be not less than four times the net area of the chimney outlet and the vertical height of the arrester shall be not less than 1.3 times the diameter of the chimney flue. Openlngs shall not permit the passage of a sphere having a diameter larger than $1 / 2$ 1nch, nor block the passage of a sphe e having a diameter of less than $3 / 8$ inch.

(h) The chImney shall extend at least three feet above the part of the roof through which it passes and at least two feet above the highest elevation of any part of the mobile home within $10 \mathrm{fee}$ of the chimney. Portions of the chlmney and termination that exceed an elevation of $131 / 2$ feet above ground level may be deslgned to be removed for transporting the mobile home.

ANSI A119.1, 1974

NO PROVISION

$$
\text { OR (ANSI A119.1, 1973) }
$$

23-920 ADDITION TO PROPOSED ANSI A119.1. (1973).

6.3.5 Solld fuel-burning factory-bu11t flreplaces and fireplace stoves listed for use in mobile homes may be installed in mobile homes provided they and their installation conform to 6.3.5.1. A fireplace of fireplace stove shall not be considered as heating facilities for determining compliance with Paragraph 7.5 of Part $B$.

6.3.5.1 A solid fuel-burning fireplace or fireplace stove shall be equipped with Integral door(s) or shutter(s) designed to close the fireplace or fireplace stove fire chamber opening and will include complete means for venting through the roof, a combustion air inlet, a hearth extension, and means to securely attach the fireplace or the fireplace stove to the moblle home structure. The installation shall conform to the following paragraphs (a) to (h) inclusive:

(a) A listed factory-built chimney designed to be attached directly to the fireplace or fireplace stove shall be used. The chimney or the flue gas outlet of the fireplace or fireplace stove shall not include a damper.

(b) A fireplace or fireplace stove air intake assembly, hearth extension and the chimney shall be installed in accordance with the terms of their listings and their manufacturer's instructions.

(c) The combustion air inlet shall conduct the air directly into the fire chamber and shall be deslgned to prevent material from the hearth dropping onto the area beneath the mobile home. The alr inlet shall not include a damper or other means of closure.

(d) The fireplace or fireplace stove shall not be installed in a sleeping room.

(e) Hearth extension shall be on noncombustible material not less than 3/8-inch thick. The hearth shall extend at least 16 inches in front of and at least 8 inches beyond each side of the fireplace of fireplace stove opening. Furthermore the hearth shall extend over tha ent1re surface beneath a flreplace stove and beneath an elevated or overhanging fireplace.

(f) The label on each solid fuel-burning f1replace and solld fuel-burning fireplace stove shall include the following wording: FOR USE WITH SOLID FUEL ONLY. 
(g) The chimney shall be provided with a spark arrester securely attached to the chimney. The net free area of the arrester shall be not less than four times the net area of the chimney outlet and the vertical height of the arrester shall be not less than 1.3 times the diameter of the chimney flue. Openings shall not permit the passage of a sphere having a diameter larger than $1 / 2$ inch, nor block the passage of a sphere having a diameter of less than $3 / 8$ inch.

(h) The chimney shall extend at least three feet above the part of the roof through which it passes and at least two feet above the highest elevation of any part of the mobile home within 10 feet of the chimney. Portions of the chimney and termination that exceed an elevation of 13 feet above ground level may be designed to be removed for transporting the mobile home.

Ref: Department of Commerce, Oregon Administrative Rules, Chapter 814, Subdivision 3, Administration of Mobile Homes and Recreational Vehicles Law. Oregon Administrative Rules.

\section{TX (ANSI A119.1, 1974)}

Documented information not received in time for inclusion in this report. The following information was given verbally:

The Performance Certification Board for Mobile Homes approved NFPA 501B, 1974, Part D, Section 6.3 .5 to be effective January $1,1975$.

\section{$6.10,1.2$ Sizing of Ducts}

ANSI AI19.1, 1975

6.10.1.2 Sizing of Ducts. Ducts shall be designed so that when a labeled forced-air furnace is installed and operated continually at its normal input rating in the mobile home, with all registers in full open position, the static pressure measured in the duct plenum shall not exceed that shown in Table 6.10.1.3, or exceed that shown on the label of the appliance. When an air-cooler coil is installed between the furnace and the duct plenum, the total static pressure between the furnace and the coil shall not exceed that shown on the label of the furnace. The minimum dimension of any branch duct shall be at least $11 / 2$ inches, and of any main duct, $21 / 2$ inches.

ANSI A119.1, 1974

6.10.1.2 Sizing of Ducts. Ducts shall be designed so that when a labeled forced-air furnace is installed and operated continually at its normal input rating in the mobile home, with all registers in full open position, the static pressure measured in the duct plenum shall not exceed that shown in Table D-4, or exceed that shown on the label of the appliance. When an air-cooler coil is installed between the furnace and the duct plenum, the total static pressure between the furnace and the coil shall not exceed that shown on the label of the furnace. The minimum dimension of any branch duct shall be at 1 east $11 / 2$ inches, and of any main duct, $21 / 2$ inches.

CO (ANSI A119.1, 1974)

(15) Add to Section 6.10.1.2, Part D:

"Group I refrigerants are the only ones acceptable for the cooler coil."

Ref: Notice of Adoption of Rules Regarding Construction Standards; Colorado Division of Housing; December 19, 1974. 
AppendiX to PART D

ANSI A119.1, $1974 \& 1975$

APPENDIX TO PART D

TABLE D-1

Standards for Heat-Produclng Appllances and Equipment

\begin{tabular}{|c|c|c|c|}
\hline Type & ANSI & UL & $\begin{array}{c}\text { Other } \\
\text { Standards }\end{array}$ \\
\hline \multicolumn{4}{|l|}{ Appliances } \\
\hline $\begin{array}{l}\text { Liquid Fuel-Burning Heating Appliances for } \\
\text { Mobile Homes and Travel Trailers }\end{array}$ & A147.1-1969 & $\begin{array}{l}307(a) \\
1969\end{array}$ & \\
\hline $\begin{array}{l}\text { Gas-Heating Appliances for Mobile Homes and } \\
\text { Trave1 Trailers }\end{array}$ & & $\begin{array}{l}307(b) \\
1965\end{array}$ & \\
\hline Gas Clothes Dryers & $221.5 .1-1972$ & & \\
\hline $\begin{array}{l}\text { Commercial Gas-Fired and Electrically-Heated } \\
\text { Hot Water Generating Equipment }\end{array}$ & & & $\begin{array}{l}\text { NSF-5 } \\
1959\end{array}$ \\
\hline $\begin{array}{l}\text { Gas-Fired Gravity and Forced Air Central } \\
\text { Furnaces }\end{array}$ & $221.47-1973$ & & \\
\hline Gas-Fired Gravity and Fan Type Floor Furnaces & $\mathrm{Z} 21.48-1973$ & & \\
\hline $\begin{array}{l}\text { Gas-Fired Gravlty and Fan Type Sealed } \\
\text { Combustion System Wal1 Furnaces }\end{array}$ & $\mathrm{Z} 21.44-1973$ & & \\
\hline Commercial Cooking and Warming Equipment & & & $\begin{array}{l}\text { NSF-4 } \\
1967\end{array}$ \\
\hline Household Cooking Gas Appliances & $z 21.1-1972$ & & \\
\hline Refrlgerators Using Gas-Fuel & $221.19-1971$ & & \\
\hline $\begin{array}{l}\text { Automatic Storage Type Water Heaters with } \\
\text { Input Less than } 75,000 \text { BTUH }\end{array}$ & $\mathrm{Z21} \cdot 10.1-1971$ & & \\
\hline
\end{tabular}

NC (ANSI A119.1, 1974)

\section{PART III--HEATING SYSTEMS CLARIFIED}

All heating, air conditioning and other heat producing appliances must be labelled by Underwriter's Laboratories and installed in accordance with the conditions of such label except that gas appliances may be AGA labelled.

Ref: State of North Carolina Regulations for Mobile Homes, 1972 Edition. 


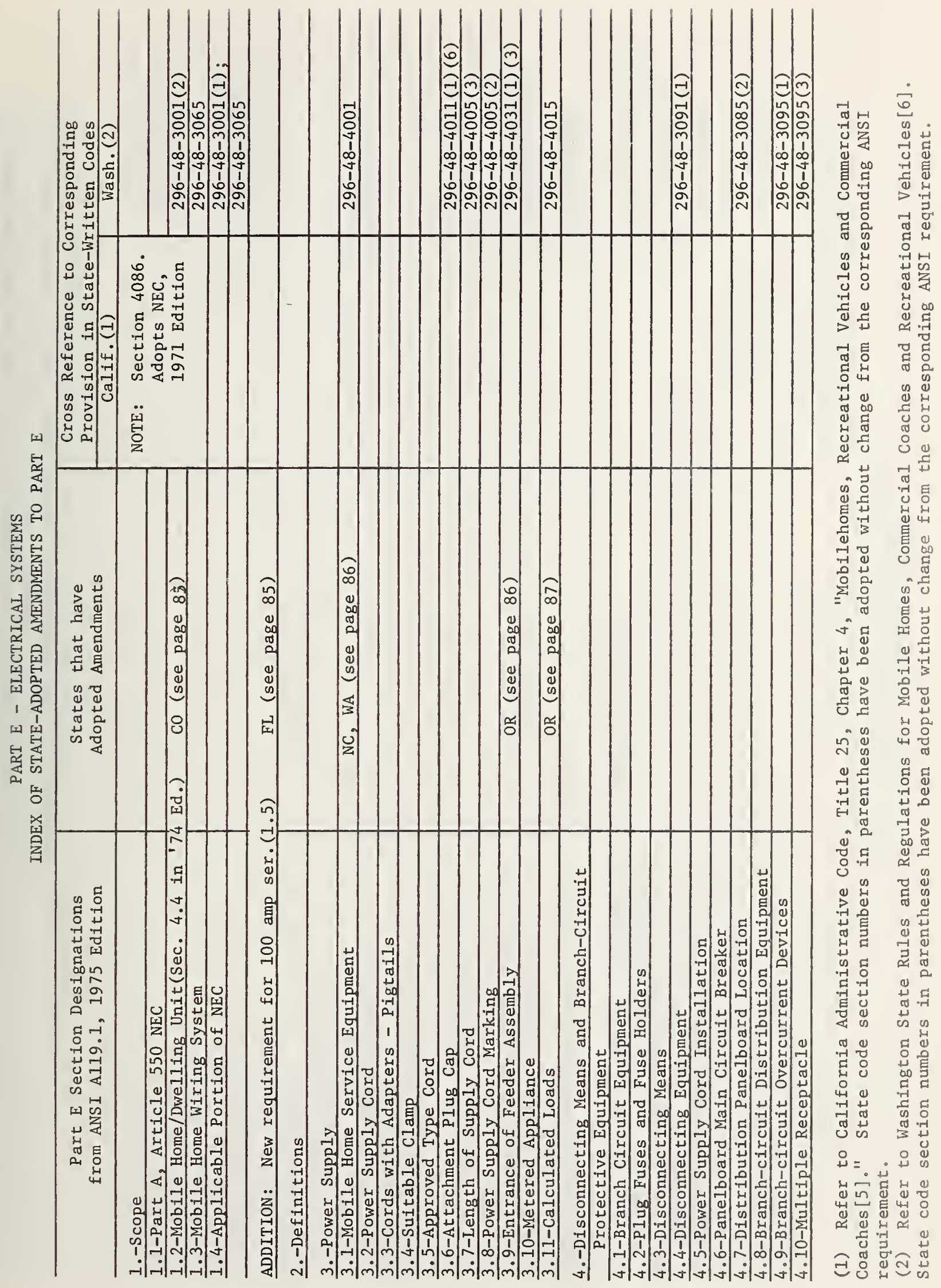




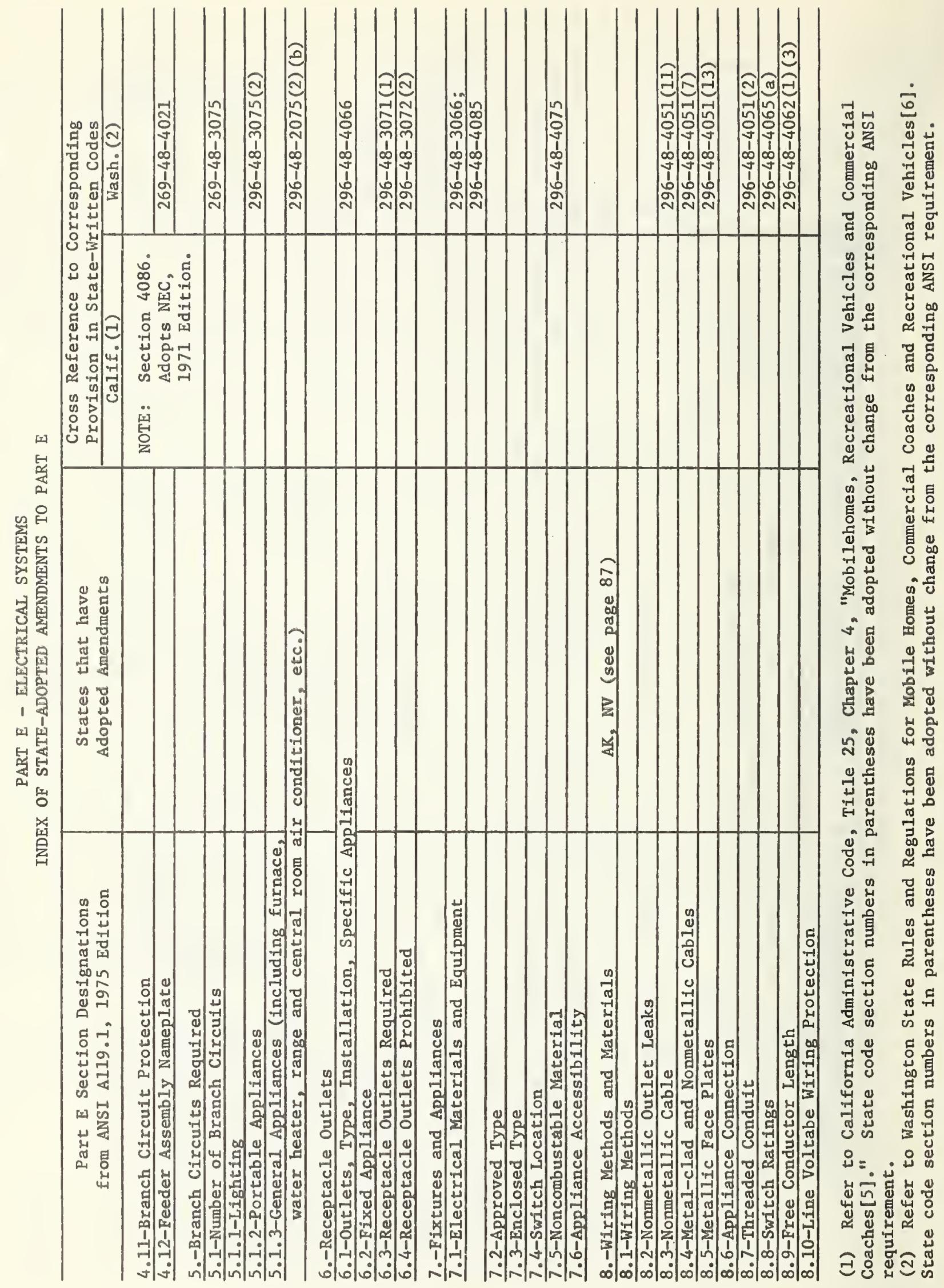




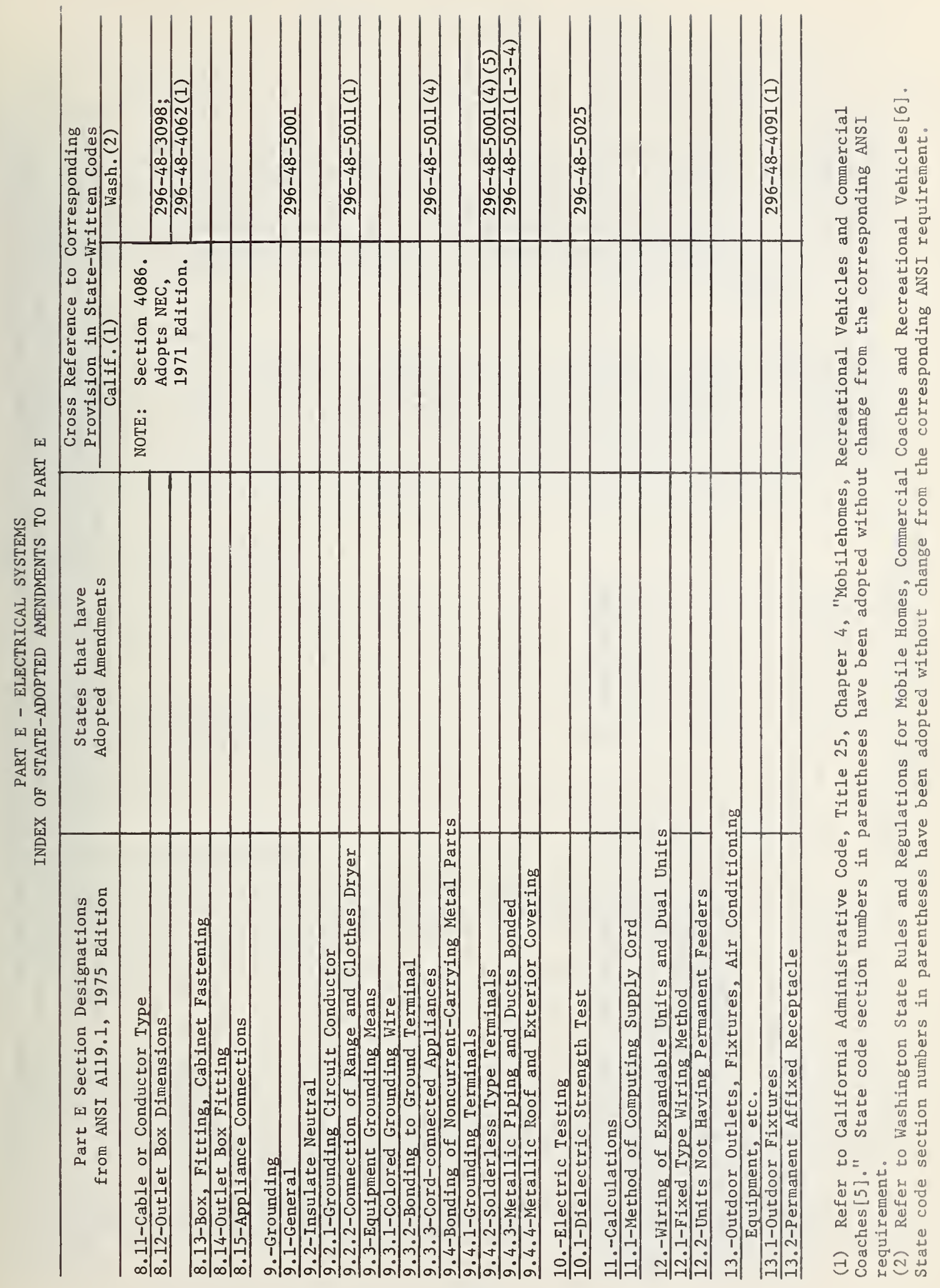



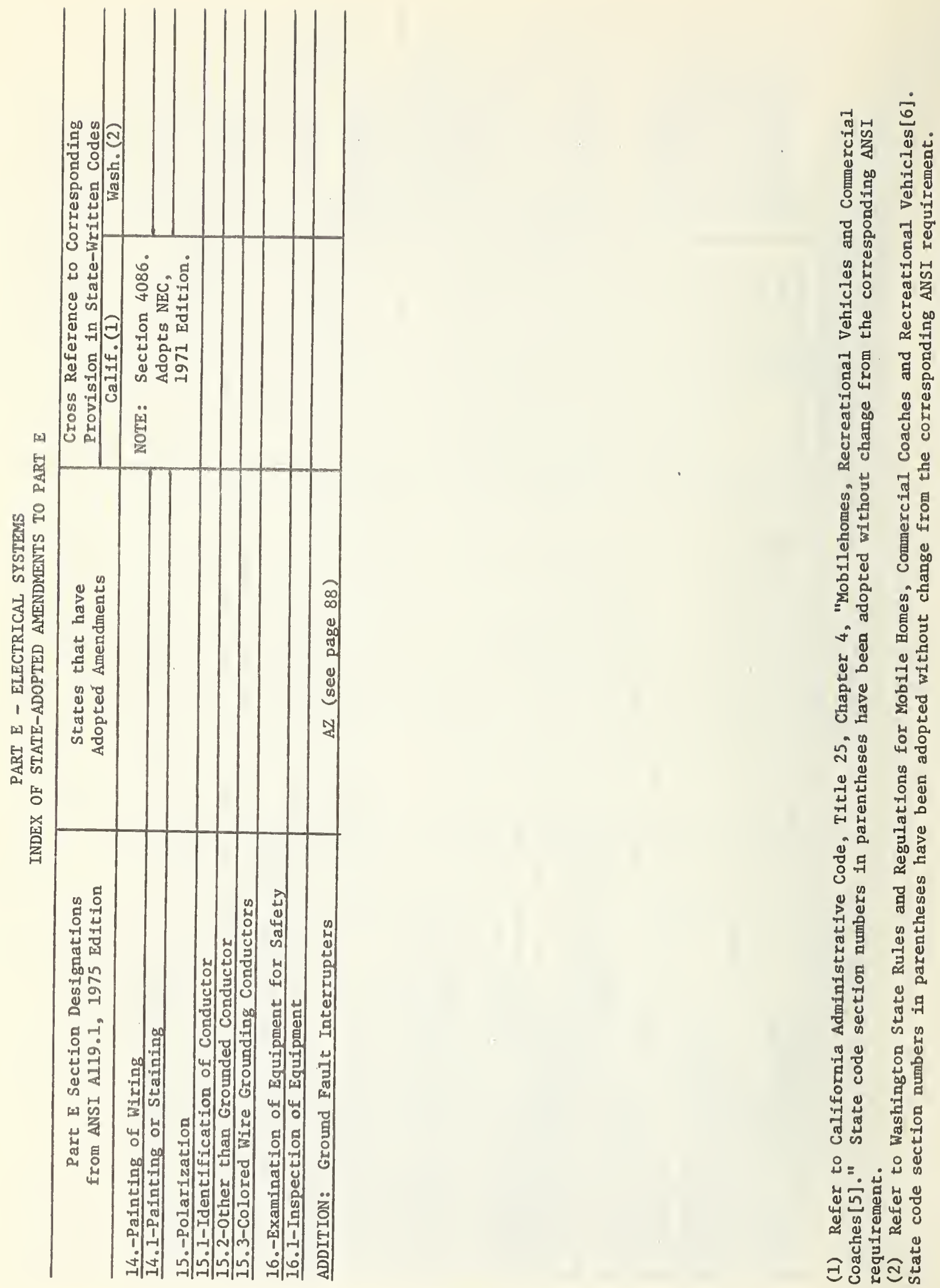


\section{PART E - ELECTRICAL SYSTEMS}

\subsection{SCOPE}

ANSI A119.1, 1975

(Corresponds to Section 4.4 in 1974 Edition.)

1.2 A mobile home not intended as a dwelling unit, as for example, equipped for sleeping purposes only, contractor's on-site offices, construction job dormitories, mobile studio dressing rooms, banks, clinics, mobile stores or intended for the display or demonstration of merchandise or machinery, shall not be required to meet the provisions of this Part pertaining to the number or capacity of circuits required. It sha11, however, meet all other applicable requirements of this Part if provided with an electrical installation intended to be energized from a 115-volt or 115/230-volt AC power supply system.

ANSI A119.1, 1974

4.4 A mobile home not intended as a dwelling unit, as for example, equipped for sleeping purposes only, contractor's on-site offices, construction job dormitories, mobile studio dressing rooms, banks, clinics, mobile stores, or intended for the display or demonstration of merchandise or machinery, shall not be required to meet the provisions of this Article pertaining to the number or capacity of circuits required. It shall, however, meet all other applicable requirements of this Part if provided with an electrical installation intended to be energized from a 115 volt or $120 / 240$ volt AC power supply system.

CO (ANSI A119.1, 1974)

(15) Delete Section 4.4, Part E.

Ref: Notice of Adoption of Rules Regarding Construction Standards; Colorado Division of Housing; December 19, 1974.

\subsection{Service Requirement}

ANSI A119.1, $1974 \& 1975$

NO PROVISION

FL (ANSI A119.1, 1974)

The manufacturer warrants that all structural elements, plumbing systems, heating, cooling and fuel burning systems, electrical systems, and fire prevention systems, are free from substantial defect. The manufacturer warrants that one hundred (100) amp electrical service exists in the mobile home.

Ref: Florida Statutes, amending Section 320-77, Chapter 74-169, House Bill No. 3499, (Section 9).

\subsection{POWER SUPPLY}

\section{ANSI A119.1, 1975}

3.1 The mobile home service equipment shall be located adjacent to the mobile home and not mounted in or on the mobile home.

The power supply to the mobile home shall be a feeder assembly consisting of not more than 3 mobile home power-supply cords, each rated 50 amperes, or a permanently installed circuit. 
Exception: A moblle home that is factory-equipped with gas or oll-fired central heating equipment and cooking appliances shall be permitted to be provided with a mobile home power-supply cord rated 40 amperes.

NC (ANSI A119.1, 1974)

\section{PART IV--ELECTRICAL SYSTEMS CLARIFIED}

The Mob1le Home Standard USAS Al19.1 defines a mob1le home as "a vehicular portable structure bullt on a chassis and designed to be used without a permanent foundation as a dwelling when connected to indicated ut1lities."

Mobile homes meeting this definition shall have the wirlng and service entrance installed to comply with Part IV of USAS Al19.1.

EXCEPTION: Two units of like construction joined together into one integral moblle home unit may have the service equipment on or in the unit provided such units comply with all of the following conditions:

1. Installed on owners lot.

2. Permanent utility connections provided.

3. Located on permanent foundation.

4. Unit is properly anchored or tied down.

5. Service equipment complies with applicable requirements of Article 230 and 250 of the National Electrical Code.

Ref: State of North Carolina, Regulations for Mobile Homes, 1972 Edition.

\section{WA (STATE CODE)}

"We require one power supply to the mobile home, not three cords as permitted by ANSI, Part E, 3.1."

Ref: Letter from State of Washington Factory-Built Housing, Mobile Home and Recreational Vehicle Section, December 6, 1974.

\subsection{POWER SUPPLY}

ANSI A119.1, 1975

3.9 The point of entrance of the feeder assembly to the mob1le home shall be in the exterior wal1. floor, or roof, in the rear third section (away from the coupler) of the mobile home.

ANSI A119.1, 1974

10.9 page 96 (Same provision as that given for 1975 Edition.)

\section{OR (ANSI A119.1, 1973)}

(3) Part E, Section 10.9 ELECTRICAL SYSTEMS. The point of entrance of the feeder assembly to the mobile home shall be in the exterior wall, floor or roof, in the rear third section within $18^{\prime \prime}$ of the left (road) side.

Ref: Department of Commerce, Oregon Administrative Rules, Chapter 814, Subchapter 3-(Administration of Mobile Homes and Recreational Vehicles). 
ANSI A119.1, 1975

3.11 (b) an approved metal raceway from the disconnecting means in the mobile home to the underside of the mobile home with provisions for the attachment of a suitable junction box or fitting to the raceway on the underside of the mobile home [with or without conductors as in $3.11(\mathrm{a})$ ].

ANSI A119.1, 1974

10.11 (b) (Same provision as that given for 1975 Edition)

OR (ANSI A119.1, 1973)

(4) Part E, Section 10.11(b) ELECTRICAL SYSTEMS. An approved raceway containing four continuous insulated, color coded, feeder conductors, one of which shall be an equipment grounding conductor, running continuously from the mobile home distribution panelboard to the underside of the mobile home. The raceway and conductors shall terminate in a properly sized junction box. Minimum size of junction boxes shall be (1) 10 in. $x 10$ in. $x 4$ in. for feeders rated not more than 100 amperes, and (2) 10 in. $x 12$ in. $x 4$ in. for feeders rated not more than 200 amperes.

Ref: Department of Commerce, Oregon Administrative Rules, Chapter 814, Subchapter 3-(Administration of Mobile Homes and Recreational Vehicles).

\section{Wiring Methods and Materials}

ANSI $A 119.1,1975$

8.1 Except as specifically limited in this Part, the wiring methods and materials specified in the National Electrical Code (NFPA No. 70--1974; ANSI CI--1974) shall be used in mobile homes.

AK (ANSI A119.1, 1972)

(7) Paragraph 4 of Part $\mathrm{E}$ is amended by adding a new subparagraph to read:

" 4.5 All wire used in the construction of the mobile home designed to carry an electrical load of 30 amperes or less shall be copper." (Effective 9/12/72, Reg. 42)

Authority: AS 54.30.010(a)

Ref: Chapter 36, Standards for Mobile Homes, (Article 2--Construction Standards), April 1973.

NV (NFPA 501B, 1973)

230. COPPERCLAD AND ALUMINUM WIRE PROHIBITED. No mobile home or travel trailer manufactured for sale in this state after the effective date of these regulations, shall be equipped with copperclad or aluminum wire except for grounds or lead-ins. This prohibition is necessitated by the fact that, although some evidence is avallable which indicates that a certain type of aluminum wire can be made safe when used with certain receptacles, the special receptacles are not readily available to the public and an adequate warning is not provided on those receptacles to the effect that improper use may create a dangerous condition.

Ref: State of Nevada, Regulations for Mobile Homes and Travel Trailers, November 1973. 
GROUND FAULT INTERRUPTERS

ANSI A119.1, $1974 \& 1975$

NO PROVISION

AZ (NFPA 501B, 1973)

\section{Ground Fault Interrupters}

All mobile homes, temporary or permanent mobile offices and recreational vehicles with a receptacle outlets rated 15 or 20 amperes at 120 volts installed on the outside of such unit shall have a ground fault interrupter (G.F.I.) Installed.

Ref: Division of Building Codes; Rules, Regulations and Standards, Title 44, Chapter 11, Article 7. 


\section{References}

[1] P. W. Cooke, H. K. Tejuja, R. D. Dikkers, L. P. Zelenka; State Building Regulatory Programs for Mobile Homes and Manufactured Buildings--A Summary; National Bureau of Standards (U.S.), Technical Note 853, 35 pages (September 1974).

[2] Copies of the Standard for Mobile Homes (NFPA 501B and ANSI A119.1) are available from National Fire Protection Association, 470 Atlantic Avenue, Boston, Massachusetts 02210; Mobile Home Manufacturers Association, 14650 Lee Road, Chantilly, Virginia 22021; and the Trailer Coach Association, 3855 E. LaPalma Avenue, Anaheim, California 92806.

[3] Dikkers, Robert D., Coordinated Evaluation System (CES) Project, National Bureau of Standards (U.S.), Technical Note 775, 12 pages (May 1973).

[4] R. D. Dikkers, H. R. Trechsel, P. W. Cooke, H. K. Tejuja, L. P. Zelenka; Model Documents for the Evaluation, Approval, and Inspection of Manufactured Buildings; National Bureau of Standards (U.S.), NBSIR 73-278, 4 Volumes (September 1973).

[5] Copies of California Administrative Code, Title 25, Chapter 4, "Mobile Homes, Recreational Vehicles and Commercial Coaches," are available from the State of California, Documents Section, P. O. Box 20191, Sacramento, California 95820.

[6] Copies of State of Washington Rules and Regulations for Mobile Homes, Commercial Coaches and Recreational Vehicles are available from the Department of Labor and Industries, Mobile Home, Commercial Coach and Recreational Vehicle Section, 300. West Harrison Street, Seattle, Washington 98119. 
APPENDIX A

LIST'ING OF STATE AGENCIES 


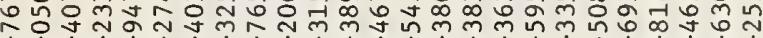

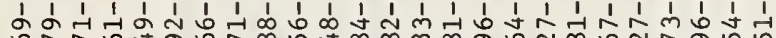


列

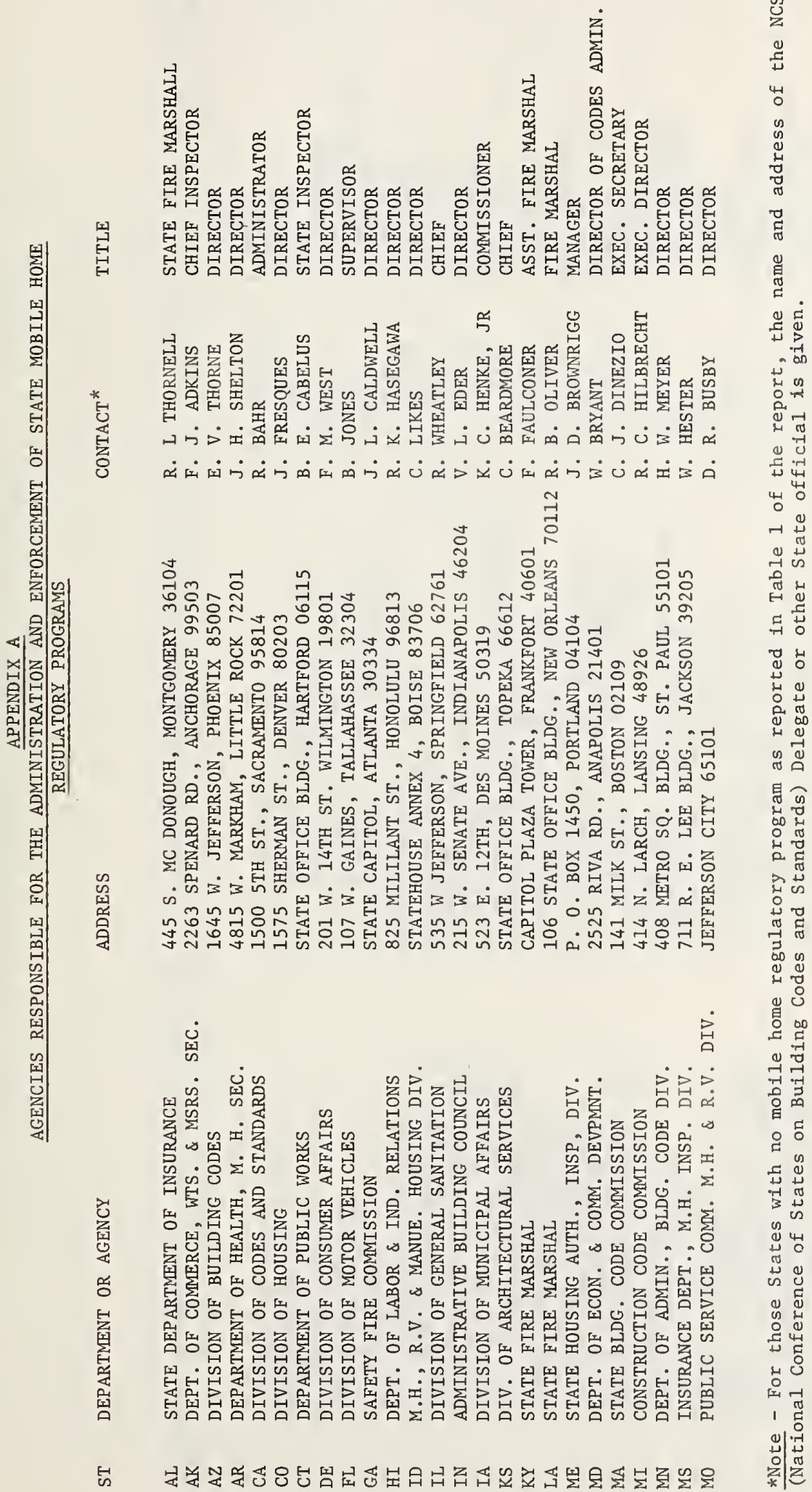






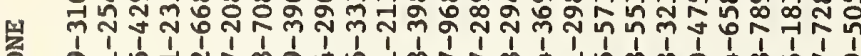
J.

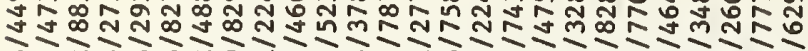



㟔

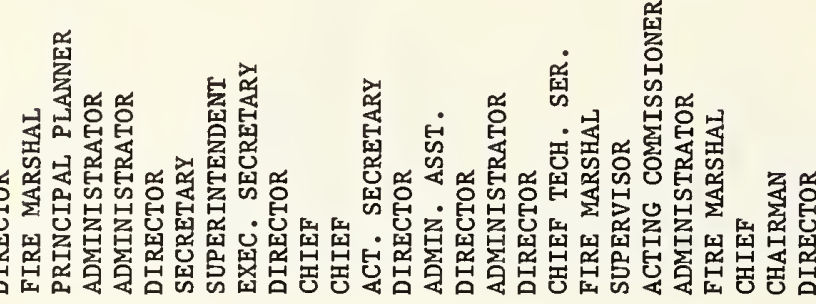
品

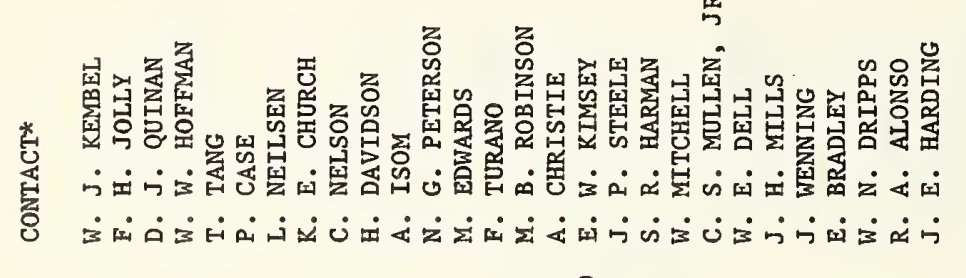

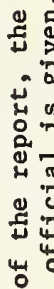

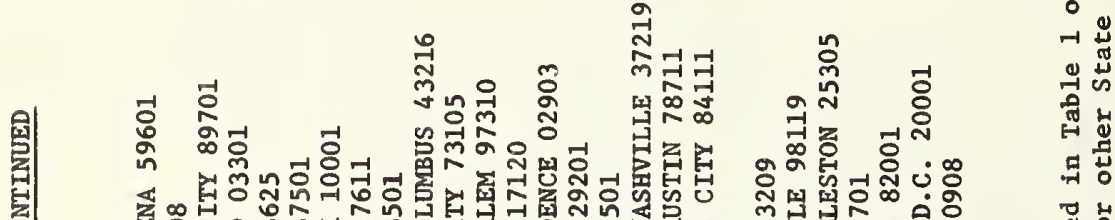

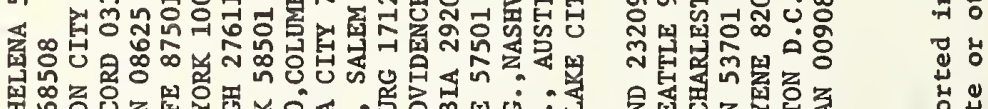

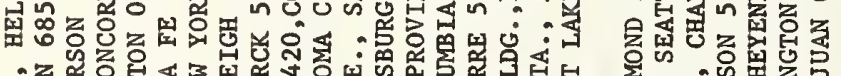

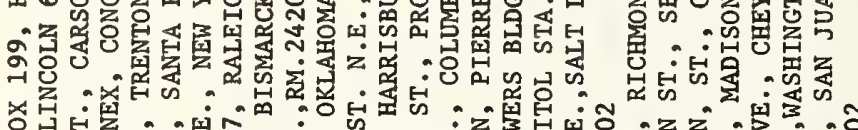





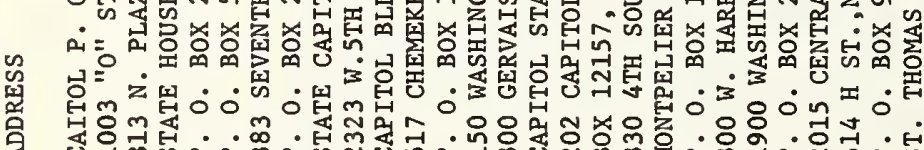





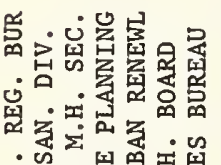

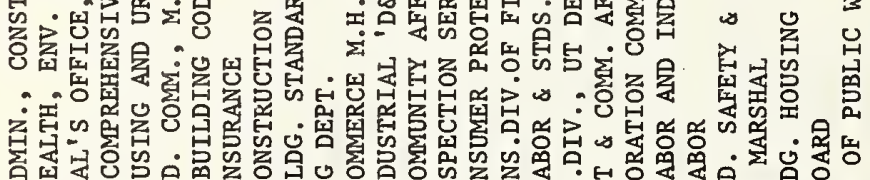

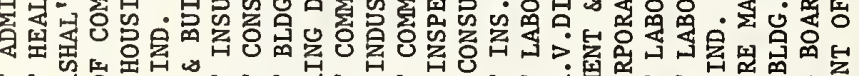

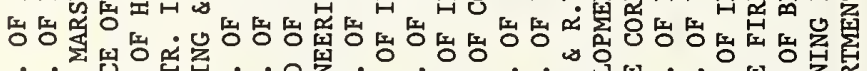

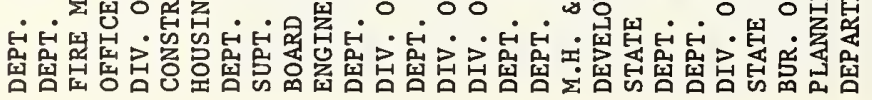

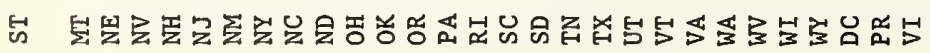


APPENDIY:

DE-FINITIONS OF "MOBILE HOME" 


\title{
APPENDIX B
}

Definition of "Mobile Home" as used in various State Iaws, rules and regulations, and statewide building codes.

\begin{abstract}
ALABAMA
"Mobile Homes" means a movable or portable dwelling over 32 feet in length and/or 8 feet or more In width, constructed to be towed on its own chassis, connected to utilities, and designed without a permanent foundation for year-round living. It can consist of one or more units that can be telescoped when towed and expanded later for additional capacity, or of two or more units, separately towable but designed to be joined into one integral unit. Ref: Alabama Law, Regular Session, 1971, Act No. 1938, Sectior. 2, A.
\end{abstract}

\section{ARIZONA}

"Mobile home" or "mobile housing" means a movable or port:able dwelling over thirty-two feet in length or over eight feet wide, constructed to be 1 :owed on its own chassis and designed so as to be installed with or without a permanent foundation for human occupancy as a residence OR AS A TEMPORARY OR PERMANENT OFFICE which may include one or more components that can be retracted for towing purposes and subsequently expanded for additional capacity, or two or more units separately towable but designed to be joined into one integral unit, as well as a portable dwelling OR OFFICE composed of a single unit, except that it does not include recreational vehicle as defined in this subsectior.

Ref: State of Arizona, House of Representatives, 31st Lerislature, First Regular Session, Chapter 74, House Bill 2025, Zrizona revised Statutis, Section 44-1701;7.

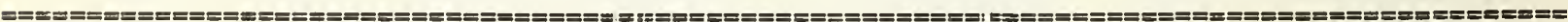

\section{CONNECTICUT}

Section 401.0 Definitions

Mobile home: a one-family dwelling unit of vehicular, pcirtable design built on a chassis and designed to be moved from one sj.te to another and to be used without a permanent foundation.

Ref: State Building Code, Effective September 1971 \& BOCA-1.970.

\section{DELAWARE}

"Mobile Home' means a movable or pirtable unit, designed and constructed to be towed on its own chassis (comprised of frame and wheels), and designei to be connected to utilities for year-round occupancy. The term. shall include: (1) unitis containing parts that may be folded, collapsed or telescoped when being towed and that ma! be expanded to provide additional cubic capacity, and (2) units, composed of two or more separately towable components designed to be joined into one intergral unit capable of being; separated again into the components for repeated towing. The term shall include units designed to be used for residential, commercial, educationa 1 or industrial purposes, excluding, however, recreational vehicles, as defined in this Act.

Ref: Delaware State Senate, 127th General Assembly, First St3ssion-1973, Senate Bill No. 273, Section 1, Amend Title 31, Crlapter 46, Section 101.

\section{INDIANA}

A movable or portable dwelling, r:onstructed to be towed on it ts own chassis, connected to utilities for year-round occupancy, which can consist of one cit more components that can be 
retracted for towing purposes, or of two or more units separately towable but designed to be joined into one integral unit.

Ref: Mobile Home Act, 1971.

A portable manufactured housing unit designed for transportation on its own chassis or placement on a temporary or permanent foundation, possessing a body width of not less than eight (8) feet overall length of not less than thirty-five (35) feet. Also, mobile home means a double wide mobile home which is two or more portable manufactured housing units, designed for placement on a temporary or permanent foundation. Any vehicle comprised of a width or a length less than the dimensions described herein is not within the definition of a mobile home.

Ref: Mobile Home Rules and Regulations.

\section{ILLINOIS}

"Mobile Home" means a movable or portable unit, designed and constructed to be towed on its own chassis (comprised of frame and wheels), and designed to be connected to utilities for year-round occupancy. The term shall include: (1) units containing parts that may be folded, collapsed or telescoped when being towed and that may be expanded to provide additional cubic capacity, and (2) units composed of two or more separately towable components designed to be joined into one integral unit capable of being separated again into the components for repeated towing. The term shall include units designed to be used for residential, commercial, educational, or industrial purposes, excluding, however, recreational vehicles, as defined in this Act.

Ref: State of Illinois, Senate Bill 844, 78th General Assembly, 1973 and 1974. Provides establishment of Safety Standards for Construction of Mobile Homes, April I4, 1973.

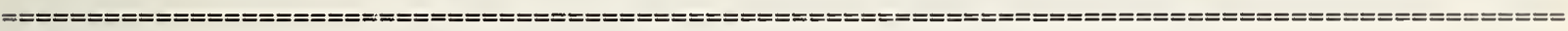

IOWA

"Mobile Home". Mobile Home means a factory-built structure or structures constructed to the standards set forth in Section $104 \mathrm{E}$ and equipped with the necessary service connections and made so as to be readily movable as a unit or units on its or their own running gear and designed to be used as a dwelling unit or units without a permanent foundation. The phrase "without a permanent foundation" indicates that the support system is constructed with the intent that the mobile home placed thereon can be moved from time to time at the the convenience of the owner. All factory-built structures which are constructed to the standards of Section $104 \mathrm{E}$ shall be considered a mobile home, regardless of its foundation. Ref: Iowa State Building Code, Administrative Section, (1-5) June 1, 1974.

KANSAS

"Mobile home" means a factory-built structure or structures more than eight (8) feet in width or more than thirty-six (36). feet in length, equipped with the necessary service connections and made so as to be readily movable as a unit or units on its or their own running gear and designed to be used as a dwelling unit or units without a permanent foundation. The phrase "without a permanent foundation" indicates that the support system is constructed with the intent that the mobile home placed thereon may be moved from time to time at the convenience of the owner.

Ref: State of Kansas, Mobile Home and Recreational Vehicle Code; Uniform Standards Code for Mobile Homes and Recreational Vehicles, (L. 1972, Chapter 338,1; July 1), Section 75-1212(g).



\section{KENTUCKY}

Mobile Home - For purposes of the Scope of the Act and regulations this means a movable or portable unit constructed to be moved from place to place on the public streets or highways and designed to permit the permanent or temporary occupancy therein for the purpose or use as a place of residence, business, profession, or trade by the owner, lessee, or their assigns and which can be connected to electric, water, gas, sewage, and telephone facilities. 
It may consist of one or more units that can be attached or joined together to comprise an integral unit or condominimum structure. It shall include house-trailers which are regulated as to length, width and registration by KRS Chapter 186. "Add-a-Room" units are not considered considered an integral part of a mobile home, therefore, manufacturer's Certificates of Acceptability and seals are required.

Ref: Department of Insurance, Office of the State Fire Marshal, Mobile Home Certification and Licensure Board. (KRS 227.57)

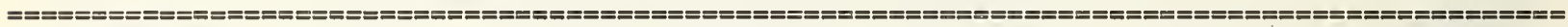

\section{LOUIS IANA}

"Mobile home" means a movable or portable dwelling constructed to be towed by a motor vehicle on its own chassis, over Louisiana roads and highways under special permit, connected to utilities, and designed without a permanent foundation for year-round living. It may consist of one or more units which can be telescoped when towed and expanded later for additional capacity, or of two or more units, separately towable but designed to be joined into one integral unit.

Ref: State of Louisiana, House Bill No. 1181, Act establishes a Uniform Standards Code for Mobile Homes; Section 2., (a).

\section{MARYLAND}

An industrialized building unit constructed on a chassis for towing to the point of use and designed to be used without a permanent foundation for continuous year-round occupancy as a dwelling. The removal of the unit from its wheels shall not be used to change its character under this act $(05.01 .01 .02 \mathrm{k})$.

Ref: Industrialized Building and Mobile Home Regulations - 1972.

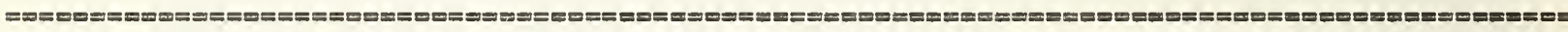

\section{MASSACHUSETTS}

MOBILE HOME: a dwelling unit built on a chassis and containing complete electrical, plumbing and sanitary facilities, and designed to be installed on a temporary or permanent foundation for permanent living quarters.

Ref: Commonwealth of Massachusetts, state Building Code, Section 1901.0.

\section{MICHIGAN}

"Mobile home" means a vehicular, portable structure built on a chassis and designed to be used without a permanent foundation as a dwelling when connected to required utilities and which is, or is intended to be attached, to the ground, to another structure, or to a utility system on the same premises for more than 30 consecutive days.

Ref: State of Michigan, 76th Legislature, Regular Session of 1972, Enrolled House Bill No. 5252, Act No. 230, approved by Governor July 27, 1972, section 2.(1),(n).

\section{MISSISSIPPI}

"Mobile Home" shall mean a movable or portable dwelling over 32 feet in length and over 8 feet wide, constructed to be towed on its own chassis, connected to utilities and designed without a permanent foundation for year-round occupancy, which can consist of one or more components that can be retracted for towing purposes and subsequently expanded for additional capacity, or of two or more units separately towable but designed to be joined into one integral unit.

Ref: State of Mississippi, Insurance Department, Mobile Home Division of State Fire Marshal's Office. 
"Mobile home" means a factory built structure or structures more than eight feet in width, equipped with the necessary service connections and made so as to be readily movable as a unit or units on its or their own running gear and designed to be used as a dwelling unit or units without a permanent foundation. The phrase 'without a permanent foundation' indicates that the support system is constructed with the intent that the mobile home placed thereon may be moved from time to time at the convenience of the owner.

Ref: State of Missouri, First Regular Session, House Bill No. 78, 77th General Assembly, Act, Section $1,(f)$.

NEVADA

"MOBILE HOME" means a vehicular structure which is built on a chassis or frame, is designed to be used with or without a permanent foundation, is capable of being drawn by a motor vehicle and is used as a dwelling when connected to utilities.

Ref: State of Nevada, Nevada State Factory-Built Housing Regulations, provisions of Chapter 233B, 461 and 477 of Nevada Revised Statutes, Section 110.

NEW JERSEY

MOBILE HOME shall mean a home, excluding travel trailers, which is a movable or portable unit, designed and constructed to be towed on its own chassis (comprised of frame and wheels), and designed to be connected to utilities for year-round occupancy. The term shall include:

(1) Units containing parts that may be folded, collapsed or telescoped when being towed and that may be expanded to provide additional cubic capacity; and

(2) Units composed of two or more separately towable components designed to be joined into one integral unit capable of being again separated into the components for repeated towing.

Ref: State of New Jersey, Department of Community Affairs, Regulations for the Uniform Standards Code for Mobile Homes, Chapter 184, P.L. 1972, December 7, 1972 Edition.

\section{NEW MEXICO}

"Mobile home" means a house trailer that exceeds a width of eight (8) feet or a length of forty (40) feet when equipped for the road, and the term includes mobile homes as inventory for sale or resale;

Ref: New Mexico Statutes, annotated volume 10, Part 1, 1973 Packet Supplement.



\section{NEW YORK}

A movable or portable unit designed and constructed to be towed on its own chassis, comprised of frame and wheels, connected to utilities, and designed and constructed without a permanent foundation for year-round living. A unit may contain parts that may be folded, collapsed or telescoped when being towed and expanded later to provide additional cubic capacity as well as two or more separately towable components designed to be joined into one integral unit capable of being separated into the components for repeated towing.

"Mobile home" shall include units designed to be used for residential, commercial, educational or industrial purposes, excluding travel trailers.

Ref: State of New York, Mobile Home Construction and Installation Standards, 1972. 
A movable or portable dwelling over 32 feet in length and over 8 feet wide, constructed to be towed on 1 ts own chassis and designed without a permanent foundation for year-round occupancy, which includes one or more components that can be retracted for towing purposes and subsequently expanded for additional capacity, or of two or more units separately towable but designed to be joined into one integral unit, as well as a portable dwelling composed of a single unit.

Ref: North Carolina, Mobile Home Code 1970.

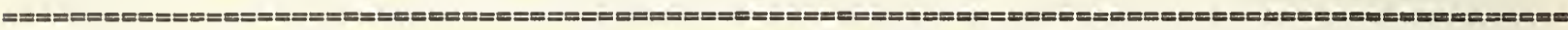

OREGON

"Mobile Home" means a vehicle or structure constructed for movement on the public highways, that has sleeping, cooking and plumbing facilities, is intended for human occupancy and is being used for residential purposes.

Ref: Department of Commerce, Oregon Administrative Rules, Chapter 814, Subdivision 3, Administration of Mobile Homes and Recreational Vehicles waw, Oregon Administrative Rules.

\section{PENNSYLVANIA}

"Mobile home" means a transportable, single-family dwelling intended for permanent occupancy, office or place of assembly contained in one unit, or in two units designed to be joined into one integral unit capable of again being separated for repeated towing, which arrives at a site complete and ready for occupancy except for minor and incidental unpacking and assembly operations, and constructed so that it may be used without a permanent foundation.

Ref: Department of Community Affairs, (16 Pennsylvania Code, Chapter 7) Uniform Standards code for Mobile Homes.

SOUTH CAROLINA

A manufactured single family dwelling or an integral part over thirty-five feet in length or over 8 feet in width, so constructed that it may be transported from one site to another, temporarily or permanently affixed to real estate, made up of one or more components, and constructed with the same or similar electrical, plumbing, heating and sanitary facilities as on-site constructed housing.

Ref: South Carolina, Uniform Standards for Mobile Home Act, 1972.

\section{SOUTH DAKOTA}

1. "Mobile home," a movable or portable unit, designed and constructed to be towed on its own chassis (comprised of frame and wheels), and designed to be connected to utilities for year-round occupancy, The term shall include:

(a) units containing parts that may be folded, collapsed or telescoped when being towed and that may be expanded to provide additional cubic capacity; and

(b) units composed of two or more separately towable components designed to be joined into the components for repeated towing.

The term shall include units designed to be used for residential, commercial, educational or industrial purposes, excluding, however, recreational vehicles, as defined in this chapter.

Ref: Department of Public Health and Safety, State Fire Marshal, Chapter 34-34A, Mobile Home Safety. 
"Mobile Home" means a factory-assembled structure or structures equipped with the necessary service connections and made so as to be readily movable as a unit or units on its (their) own running gear and designed to be used as a dwelling unit(s) without a permanent foundation, which can consist of one or more components that can be retracted for towing purposes and subsequently expanded for additional capacity, or of two or more units separately towable but designed to be joined into one integral unit.

Ref: State of Tennessee, House Bill No. 1850 (substitute Senate Bill No. 1657), "The Uniform Standards Code for Factory-Manufactured Mobile Homes Act," Section 2, (a).

\section{TEXAS}

A movable or portable dwelling constructed to be towed by a motor vehicle on its own chassis, over Texas roads and highways under special permit, connected to utilities, and designed without a permanent foundation for year-round living. It may consist of one or more units that can be telescoped when towed and expanded later for additional capacity or of two or more units, separately towable but designed to be joined into one integral unit. Ref: Texas, Uniform Standards Code for Mobile Homes - 1971.

The words "mobile home" mean a vehicular, portable structure built on a chassis and designed to be used without a permanent foundation as a dwelling when connected to indicated utilities.

Ref: Utah Code, Title 41, Chapter 20, Mobile Homes, Travel Trailers or Recreational Vehicles.

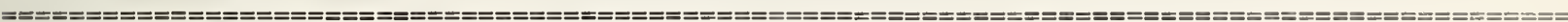

\section{VIRGINIA}

"Mobile home" means an industrialized building unit constructed on a chassis for towing to the point of use and designed to be used, without a permanent foundation for continuous year-round occupancy as a dwelling; or two or more such units separately towable, but designed to be joined together at the point of use to form a single dwelling, and which is designed for removal to, and installation or erection on other sites.

Ref: Code of Virginia, Industrialized Building Unit and Mobile Home Safety Law, Title 36, Chapter 4, Section 36-70 to 36-85.



\section{WEST VIRGINIA}

MOBILE HOME OR UNIT means a movable or portable unit, designed and constructed to be towed on its own chassis (comprised of frame and wheels), and designed to be connected to utilities for year-round occupancy. The term includes:

(a) Units containing parts that may be folded, collapsed or telescoped when being towed and that may be expanded to provide additional cubic capacity; and

(b) Units composed of two or more separately towable components designed to be joined into one integral unit capable of being separated again into the components for repeated towing.

The term includes units designed to be used for residential, commercial, educational, or industrial purposes, excluding, however, recreational vehicles, as defined in these regulations. In addition to compliance with the regulations, any Mobile Home to be used by an educational institution, school board, or university, must be approved by the State Fire Marshal.

Ref: State of West Virginia, West Virginia Department of Labor, pursuant to West Virginia Mobile Home Safety Act, West Virginia Code, Chapter 21, Article 9, Section 100-6. 


\section{WISCONSIN}

"Mobile home" means a vehicle designed to be towed as a single unit or in sections upon a highway by a motor vehicle and equipped and used or intended to be used, primarily for human habitation, with walls or rigid uncollapsible construction, which has an overall length In excess of 45 feet. "Mobile home" includes the mobile home structure, including the plumbing, heating, and electrial systems and all appliances and all other equipment carrying a manufacturer's warranty.

Ref: State of Wisconsin, 1973 Assembly Bill 569, Chapter 116, Section 3, 218.10. 
APPENCIX C

SI CONVERSION UNITS 


\section{APPENDIX C}

\section{SI Conversion Units}

In view of the present accepted practice in this country for building technology, common U.S. units of measurement have been used throughout this publication. In recognition of the position of the United States as a signatory to the General Conference on Weights and Measures, which gave official status to the metric SI system of units on 1960, appropriate conversion factors have been provided in the table below. The reader interested in making further use of the coherent system of SI units is referred to:

NBS SP330, 1972 Edition, "The International System of Units"

E380-72 ASTM Metric Practice Guide (American National Stanciard 2210.1)

Table of Conversion Factors to Metric (S.I.) Units

\begin{tabular}{|c|c|c|c|}
\hline $\begin{array}{l}\text { Physical } \\
\text { Quantity }\end{array}$ & $\begin{array}{c}\text { To convert } \\
\text { from }\end{array}$ & $\begin{array}{l}\text { to } \\
\text { to }\end{array}$ & multiply by \\
\hline \multirow[t]{2}{*}{ Length } & Inch & meter & $2.54 * \times 10^{-2}$ \\
\hline & foot & m & $3.048 * \times 10^{-1}$ \\
\hline \multirow[t]{2}{*}{ Area } & inch 2 & $\mathrm{~m}^{2}$ & $6.4516 * \times 10^{-4}$ \\
\hline & foot ${ }^{2}$ & $\mathrm{~m}^{2}$ & $9.290 \times 10^{-2}$ \\
\hline \multirow[t]{2}{*}{ Volume } & Inch 3 & $\mathrm{~m}^{3}$ & $1.639 \times 10^{-5}$ \\
\hline & foot $^{3}$ & $\mathrm{~m}^{3}$ & $2.832 \times 10^{-2}$ \\
\hline Temperature & Fahrenhe1t & Celsius & $t_{C}=\left(t_{\mathrm{F}-32}\right) / 1.8$ \\
\hline Temperature difference & Fahrenheit & Kelvin & $K=\left(\Delta t_{F}\right) / 1.8$ \\
\hline Pressure & inch $\mathrm{Hg}(60 \mathrm{~F})$ & newton $/ \mathrm{m}^{2}$ & $3.377 \times 10^{3}$ \\
\hline Mass & $1 \mathrm{bm}$ & $\mathrm{kg}$ & $4.536 \times 10^{-1}$ \\
\hline Mass/unit area & $1 \mathrm{bm} / \mathrm{ft} \mathrm{t}^{2}$ & $\mathrm{~kg} / \mathrm{m}^{2}$ & 4.882 \\
\hline Moisture content rate & $1 \mathrm{bm} / \mathrm{ft} \mathrm{t}^{2}$ week & $\mathrm{kg} / \mathrm{m}^{2} \mathrm{~s}$ & $8.073 \times 10^{-6}$ \\
\hline Density & $1 \mathrm{bm} / \mathrm{ft}^{3}$ & $\mathrm{~kg} / \mathrm{m}^{3}$ & $1.602 \times 10^{1}$ \\
\hline Thermal conductivity & $\mathrm{Btu} / \mathrm{hr} \mathrm{ft}^{2}$ (F/inch) & $\frac{\mathrm{W}}{\mathrm{mK}}$ & $1.442 \times 10^{-1}$ \\
\hline U-value & Btu/hr ft ${ }^{2} \mathrm{~F}$ & $\frac{\mathrm{W}}{\mathrm{m}^{2} \mathrm{~K}}$ & 5.678 \\
\hline Thermal resistance & $F /\left(B t u / h r f t^{2}\right)$ & $\mathrm{K} /\left(\mathrm{W} / \mathrm{m}^{2}\right)$ & $1.761 \times 10^{-1}$ \\
\hline Heat flow & $B t u / h r f t^{2}$ & $\mathrm{~W} / \mathrm{m}^{2}$ & 3.155 \\
\hline
\end{tabular}

*Exact value; others are rounded to fourth place. 
NBS-114A IRE, V. 7.73\}

\begin{tabular}{|c|c|c|c|}
\hline $\begin{array}{l}\text { U.S. DEPT. OF COMM. } \\
\text { BIBLIOGRAPHIC DATA } \\
\text { SHEET }\end{array}$ & $\begin{array}{l}\text { 1. PUBLICATION OR REPORT NO. } \\
\text { NBS IR } 75-680\end{array}$ & $\begin{array}{l}\text { 2. Gov't Accession } \\
\text { No. }\end{array}$ & 3. Recipient's Accession No. \\
\hline \multirow{3}{*}{\multicolumn{3}{|c|}{$\begin{array}{l}\text { 4. TITLE AND SUBTITLE } \\
\text { Mobile Home Construction Standards Adopted by } \\
\text { State Regulatory Programs--An Analysis }\end{array}$}} & 5. Publication Date \\
\hline & & & March 1975 \\
\hline & & & 6. Performing Organization Code \\
\hline $\begin{array}{l}\text { 7. AUTHOR(S) } \\
\text { Patrick W. Cooke }\end{array}$ & uis P. Zelenka, Hotchand & Tejuja & $\begin{array}{l}\text { 8. Performing Organ. Report No. } \\
\text { NBSIR } 75-680\end{array}$ \\
\hline \multirow{2}{*}{\multicolumn{3}{|c|}{$\begin{array}{l}\text { 9. PERFORMING ORGANIZATION NAME AND ADDRESS } \\
\text { NATIONAL BUREAU OF STANDARDS } \\
\text { DEPARTMENT OF COMMERCE } \\
\text { WASHINGTON, D.C. } 20234\end{array}$}} & $\begin{array}{l}\text { 10. Project/Task/Work Unit No. } \\
4601132\end{array}$ \\
\hline & & & 11. Contract/Grant No. \\
\hline \multirow{3}{*}{\multicolumn{3}{|c|}{ 12. Sponsoring Organization Name and Complete Address (Street, City, State, ZIP) }} & $\begin{array}{l}\text { 13. Type of Report \& Period } \\
\text { Covered }\end{array}$ \\
\hline & & & Preliminary \\
\hline & & & 14. Sponsoring Agency Code \\
\hline
\end{tabular}

\section{SUPPLEMENTARY NOTES}

16. ABSTRACT (A 200-word or less factual summary of most si, th wh mation. If document includes a significant bibliography or literature survey, mention it here.)

This study examines the extent to which the nationally recognized standard for the construction of mobile homes (i.e., ANSI Standard A119.1/NFPA 501B) has been adopted and amended by the individual states that have implemented enforcement programs for the regulation of mobile homes. Summary data is presented on the existing status of the various versions of the standard adopted in each State. State-adopted amendments to the technical requirements in the national standard are compiled by state and construction discipline for comparative analysis.

17. KEY WORDS (six to twelve entries; alphabetical order; capitalize only the first letter of the first key word unless a proper name; separated by semicolons)

Enforcement; legislation; mobile homes; regulation; standards; state-of-the-art study.

18. AVAILABILITY $\overline{X X}$ Unlimited

$\square$ For Official Distribution. Do Not Release to NTIS

$\square$ Order From Sup. of Doc., U.S. Government Printing Office Washington, D.C. 20402, SD Cat. No. C13

$\square$ Order From National Technical Information Service (NTIS) Springfield, Virginia 22151

\begin{tabular}{|l|c|}
\hline $\begin{array}{l}\text { 19. SECURITY CLASS } \\
\text { (THIS REPURT) }\end{array}$ & 21. NO. OF PAGES \\
UNCL ASSIFIED & 100 \\
\hline $\begin{array}{c}\text { 20. SECURITY CLASS } \\
\text { (THIS PAGE) } \\
\text { UNCLASSIFIED }\end{array}$ & 22. Price \\
\hline
\end{tabular}


